\title{
Site Observational Work Plan FOR THE UMTRA PROJECT SITE AT SHIPROCK, NEW MEXICO
}

RECFIIE?

OCT 171904

OS 11

September 1994

\section{DISCLAIMER}

This report was prepared as an account of work sponsored by an agency of the United States Government. Neither the United States Government nor any agency thereof, nor any of their employees, makes any warranty, express or implied, or assumes any legal liability or responsibility for the accuracy, completeness, or usefulness of any information, apparatus, product, or process disclosed, or represents that its use would not infringe privately owned rights. Reference herein to any specific commercial product, process, or service by trade name, trademark, manufacturer, or otherwise does not necessarily constitute or imply its endorsement, recommendation, or favoring by the United States Government or any agency thereof. The views and opinions of authors expressed herein do not necessarily state or reflect those of the United States Government or any agency thereof. 


\section{DISCLAIMER}

Portions of this document may be illegible in electronic image products. Images are produced from the best available original document. 


\section{INTENDED FOR PUBLIC RELEASE}

This report has been reproduced from the best available copy. Available in paper copy and microfiche.

Number of pages in this report: 88

DOE and DOE contractors can obtain copies of this report from:

Office of Scientific and Technical Information

P.O. Box 62

Oak Ridge, TN 37831

(615) 576-8401

This report is publicly available from:

National Technical Information Service

Department of Commerce

5285 Port Royal Road

Springfield, VA 22161

(703) $487-4650$ 


\title{
SITE OBSERVATIONAL WORK PLAN FOR THE UMTRA PROJECT SITE AT SHIPROCK, NEW MEXICO
}

September 1994

\author{
Prepared for \\ U.S. Department of Energy \\ UMTRA Project Office \\ Albuquerque, New Mexico \\ Prepared by \\ Jacobs Engineering Group Inc. \\ Albuquerque, New Mexico
}




\section{EXECUTIVE SUMMARY}

The site observational work plan (SOWP) for the Shiprock, New Mexico, Uranium Mill Tailings Remedial Action (UMTRA) Project Site is the initial document for developing sitespecific activities to achieve regulatory compliance in the UMTRA Ground Water Project. The regulatory framework used to select the proposed ground water compliance strategies is presented along with a discussion of the relationship of this SOWP to other UMTRA Ground Water Project programmatic documents.

The Shiprock site consists of two, interconnected hydrogeologic systems: the terrace system and the floodplain system. Separate compliance strategies are proposed for these two systems. The compliance strategy for the terrace aquifer is no remediation with the application of supplemental standards based on classification of the terrace aquifer as having Class III (limited-use) ground water. The compliance strategy for the floodplain aquifer is active remediation using a subsurface biological barrier. These strategies were selected by applying site-specific data to the compliance framework developed in the UMTRA Ground Water programmatic environmental impact statement (PEIS) (DOE, 1994a).

The site conceptual model indicates that milling-related contamination has impacted the ground water in the terrace and floodplain aquifers. Ground water occurs in both aquifers in alluvium and in fractures in the underlying Cretaceous age Mancos Shale. A mound of ground water related to fluids from the milling operations is thought to exist in the terrace aquifer below the area where settling ponds were in use during the mill operations. Most of the water occurring in the floodplain aquifer is from recharge from the San Juan River.

Recovery data from monitor wells on the terrace suggest that the terrace aquifer has a very low yield. Therefore, the small amount of ground water naturally occurring in the terrace aquifer qualifies the ground water as limited-use ground water based on a sustained well yield of less than 150 gallons per day.

Contamination in the floodplain aquifer comes from the mound of mill-related water in the terrace by way of seeps and fracture flow through the Mancos Shale. During the operation of the mill, process waters may have been diverted to settling ponds on the floodplain and may have spilled onto the floodplain by water overflowing from the settling ponds on the terrace. Because contaminated ground water in the floodplain aquifer has higher densities than unimpacted ground water, it may be trapped in low areas of erosional structures on the top of the Mancos Shale. The presence of trapped water may impact the remediation proposed for the floodplain aquifer. There are 19 potential contaminants of concern in ground water in the terrace and floodplain aquifers. Active remediation of the floodplain aquifer is recommended to mitigate any risks to human health and the environment from these constituents present in ground water at the site.

An assessment of site-specific data indicates that a number of data needs must be addressed before implementing any compliance strategies at the site. A variety of data collection activities are proposed which will fulfill these data needs. The data to be collected during these activities will help define the horizontal and vertical extent of 
contamination in ground water, characterize aquifer properties, and define biological and geochemical processes in the aquifer. These data will then be used to determine the effectiveness of the proposed compliance strategies and the feasibility of the proposed remediation method for the floodplain aquifer. 


\section{TABLE OF CONTENTS}

Section

Page

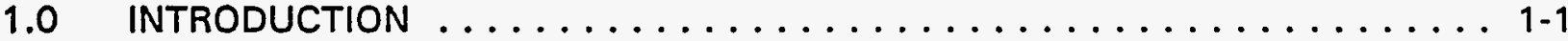

1.1 Purpose and content ......................... 1-1

1.2 Proposed ground water compliance strategies . . . . . . . . . . . 1-1

1.3 Relationship to programmatic umtra ground water documents . . . . . . 1-2

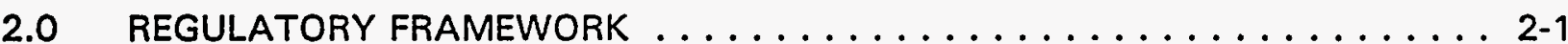

2.1 Uranium Mill Tailings Radiation Control Act . . . . . . . . . . . . . 2-1

2.1.1 Environmental Protection Agency ground water compliance standards ......................... 2-1

2.1.2 Cooperative agreements .................. 2-4

2.2 National environmental policy act . . . . . . . . . . . . . . . 2-4

3.0 SUMMARY OF SITE CONDITIONS $\ldots \ldots \ldots \ldots \ldots \ldots \ldots \ldots \ldots \ldots$

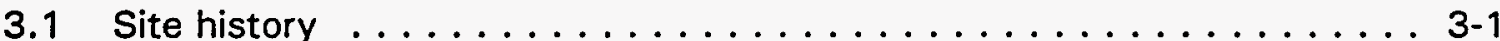

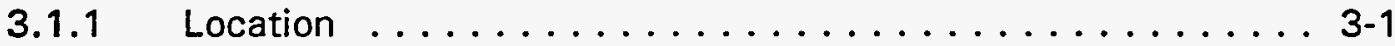

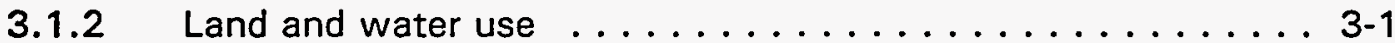

3.1.3 History of operations . . . . . . . . . . . . . . . . 3-4

3.1.4 Surface remedial action and ground water protection strategy . . . . . . . . . . . . . . . . . 3-7

3.2 Sources of existing data $\ldots \ldots \ldots \ldots \ldots \ldots \ldots \ldots \ldots \ldots \ldots$

3.3 Conceptual site model . . . . . . . . . . . . . . . . . 3-8

3.3.1 Hydrogeologic setting .................. 3-8

3.3.2 Ground and surface water quality . . . . . . . . . . . 3-21

3.3.3 Contaminant fate and transport . . . . . . . . . . . 3-32

3.3.4 Risk evaluation . . . . . . . . . . . . . . . . 3-38

3.4 Evaluation of interim action opportunities $\ldots \ldots \ldots \ldots \ldots \ldots$ 3-40

4.0 GROUND WATER COMPLIANCE STRATEGY SELECTION $\ldots \ldots \ldots \ldots$

4.1 Ground water compliance strategy . . . . . . . . . . . . . . . 4-1

4.2 Site-specific ground water compliance strategies ............ 4-1

4.2.1 Terrace compliance strategy . . . . . . . . . . . . . 4 4-4

4.2.2 Floodplain compliance strategy .............. . 4-4

4.3 Deviations, contingencies, and decision rules . . . . . . . . . . 4-7

4.3 .1 Terrace aquifer . . . . . . . . . . . . . . . 4-7

4.3.2 Floodplain aquifer $\ldots \ldots \ldots \ldots \ldots \ldots \ldots \ldots \ldots$. . . . . .

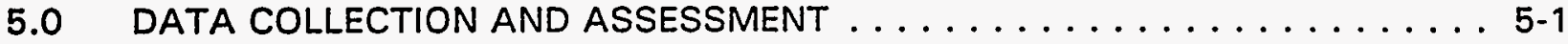

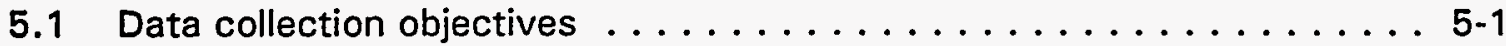

5.2 Statement of data needs ...................... 5-1

5.3 Data collection activities and quality objectives $\ldots \ldots \ldots \ldots \ldots \ldots \ldots$ 5-2

5.3.1 Surface geophysical surveys ............... 5-3

5.3.2 Borehole fluid conductivity surveys $\ldots \ldots \ldots \ldots \ldots \ldots$. . . . . . .

5.3 .3 Core analysis . . . . . . . . . . . . . . . 5-6

5.3 .4 Monitor well installation $\ldots \ldots \ldots \ldots \ldots \ldots \ldots$ 
TABLE OF CONTENTS (Concluded)

Section

Page

5.3 .5 Piezometer installations ................. 5-7

5.3 .6 Aquifer testing . . . . . . . . . . . . . . . 5-8

5.3.7 Water quality sampling and analysis . . . . . . . . . 5-9

5.3.8 Geochemical analysis of lithologic samples . . . . . . . . . 5-10

5.3.9 Biological sampling of ground water . . . . . . . . . 5-10

5.3.10 Surface water and sediment sampling ............ 5-11

5.4 Results and evaluation of data collection activities .......... 5-11

6.0 LIST OF CONTRIBUTORS ..................... 6 .1

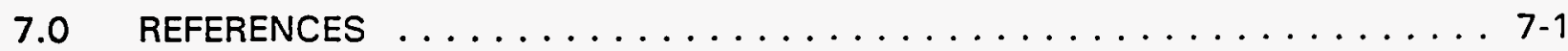




\section{LIST OF FIGURES}

\section{Figure}

Page

3.1 Shiprock site location map, Shiprock, New Mexico . . . . . . . . . . . . 3-2

3.2 Physiographic setting, Shiprock, New Mexico, site . . . . . . . . . . . . . 3-3

3.3 Aerial view of Shiprock site in operating period, Shiprock, New Mexico, site .. 3-5

3.4 Generalized cross section A-A', Shiprock, New Mexico, site . . . . . . . . . 3-9

3.5 Bedrock surface contours on terrace, Shiprock, New Mexico, site ....... 3-11

3.6 Bedrock surface contours on floodplain, Shiprock, New Mexico, site . . . . 3 3-14

3.7 Fence diagram of floodplain stratigraphy, Shiprock, New Mexico, site . . . . . 3-16

3.8 Ground water table contours and gradient on floodplain, Shiprock, New Mexico, site ............................... 3-17

3.9 Ground water monitor well locations, Shiprock, New Mexico, site . . . . . . 3-19

3.10 Locations of floodplain surface water and sediment sampling stations adjacent to Shiprock tailings site, Shiprock, New Mexico, site . . . . . . . . . 3-20

3.11 Background wells used for qualitative (SJ3, G10) and quantitative (732, $733,634,635)$ analysis of ground water in the floodplain aquifer, Shiprock, New Mexico, site . . . . . . . . . . . . . . . . . . . . 3-22

3.12 Sulfate concentrations in floodplain alluvium, Shiprock, New Mexico, site . . . 3-29

3.13 Nitrate concentrations in floodplain alluvium, Shiprock, New Mexico, site . . . 3-30

3.14 Uranium concentrations in floodplain alluvium, Shiprock, New Mexico, site .. 3-31

4.1 Shiprock terrace compliance selection framework, Shiprock, New Mexico,

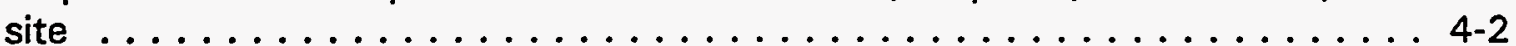

4.2 Shiprock floodplain compliance selection framework, Shiprock, New Mexico, site .................................. 4-3

4.3 Application of constituents to compliance selection framework for the floodplain, Shiprock, New Mexico, site . . . . . . . . . . . . . . . 4-5

5.1 Location for surface geophysical surveys, Shiprock, New Mexico, site . . . . 5 5-5 


\section{LIST OF TABLES}

Table

Page

2.1 Maximum concentrations of inorganic constituents for ground water protection for UMTRA Project sites . . . . . . . . . . . . . . . 2-3

3.1 Statistical summary of constituents of concern in the San Juan River floodplain aquifer, 1987-1993 filtered samples, Shiprock, New Mexico,

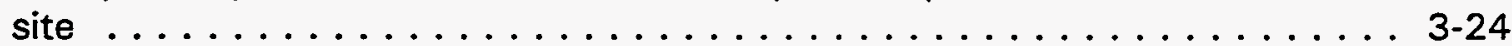

3.2 Summary of constituents of concern in ground water in the terrace aquifer, Shiprock, New Mexico, site, 1988-1993 . . . . . . . . . . . . . . 3-26

3.3 Statistical summary of the San Juan River water quality at the Shiprock, New Mexico, site, February 25, $1993 \ldots \ldots \ldots \ldots \ldots \ldots$. . . . . . . . . . . . . 


\section{LIST OF ACRONYMS AND ABBREVIATIONS}

\section{Acronym Definition}

ac

$A C L$

AEC

ASTM

BIA

CFR

$\mathrm{cm}$

$\mathrm{cm} / \mathrm{s}$

$\mathrm{COC}$

DCO

DO

DOE

DQO

EA

EM

EPA

FR

$\mathrm{ft}$

$\mathrm{ft} / \mathrm{day}$

gal

gpm

GWPP

ha

JEG

$\mathrm{km}$

L

$\mathrm{L} / \mathrm{min}$

$\mathrm{MCL}$

$\mathrm{mg} / \mathrm{L}$

mi

MSL

n.d.

NECA

NEPA

NRC

NTUA

pCi/L

PEIS

PVC

QA

RAP

RRM

SOP

SOW acre

alternate concentration limit

Atomic Energy Commission

American Society for Testing Materials

Bureau of Indian Affairs

Code of Federal Regulations

centimeter

centimeters per second

constituent of concern

data collection objective

dissolved oxygen

U.S. Department of Energy

data quality objective

environmental assessment

electromagnetic

U.S. Environmental Protection Agency

Federal Register

foot

feet per day

gallon

gallons per minute

Groundwater Project Plan

hectare

Jacobs Engineering Group

kilometer

liter

liters per minute

maximum concentration limit

milligrams per liter

mile

mean sea level

no date

Navajo Engineering and Construction Authority

National Environmental Policy Act

U.S. Nuclear Regulatory Commission

Navajo Tribal Utility Authority

picocuries per liter

programmatic environmental impact statement

polyvinyl chloride

quality assurance

remedial action plan

residual radioactive material

standard operating procedure

statement of work 


\section{LIST OF ACRONYMS AND ABBREVIATIONS (Concluded)}

$\begin{array}{ll}\text { Acronym } & \text { Definition } \\ \text { SOWP } & \text { site observational work plan } \\ \text { TAC } & \text { Technical Assistance Contractor } \\ \text { TAGR } & \text { Technical Approach to Groundwater Restoration } \\ \text { TDS } & \text { total dissolved solids } \\ \text { TEM } & \text { transient electromagnetic } \\ \text { UMTRA } & \text { Uranium Mill Tailings Remedial Action } \\ \text { UMTRCA } & \text { Uranium Mill Tailings Radiation Control Act } \\ \text { USC } & \text { United States Code } \\ \text { USGS } & \text { U.S. Geological Survey }\end{array}$




\subsection{INTRODUCTION}

The Shiprock, New Mexico, site observational work plan (SOWP) is the initial U.S. Department of Energy (DOE) Uranium Mill Tailings Remedial Action (UMTRA) Ground Water Project document for determining site-specific activities to achieve compliance with the proposed U.S. Environmental Protection Agency (EPA) ground water standards (40 CFR Part 192 (1994)\}.

\section{$1.1 \quad$ PURPOSE AND CONTENT}

The purpose of this SOWP is to present a plan for additional data collection efforts to resolve identified data gaps and to assist in selecting or substantiating the appropriate ground water compliance strategies at the Shiprock UMTRA Project processing site. The proposed compliance strategies are supported through a summary of all existing data in a site conceptual model. The site conceptual model describes the source of the constituents of concern (COC); defines the current conditions and potential environmental and human health risks; and identifies data gaps in the site conceptual model. Defensible data collection objectives (DCO) and appropriate data quality objectives (DQO) are presented.

Section 2.0 describes the regulatory framework for selecting ground water compliance strategies for UMTRA Project sites. Section 3.0 defines the current conditions at Shiprock and presents the site conceptual model, which includes potential environmental and human health risks, to support the proposed ground water compliance strategy. Section 4.0 provides the justification for selecting the proposed ground water compliance strategy. Section 5.0 presents additional data collection needs and activities that will be performed to verify and refine the proposed remediation methods within the framework of the proposed compliance strategies.

Three versions of the SOWP will be prepared: Revision 0 (initial submittal), Revision 1 , and Revision 2 (final revision). Following this initial SOWP, Revision 1 will include all previously existing ground water data from the site, describe the additional data collected, describe how these data relate to previous information presented in the site conceptual model and the proposed compliance strategies, and summarize the results relative to the DCOs. Revision 1 will also propose a pilot field program for observing the effectiveness of the selected remediation. The final revision (Revision 2) of the Shiprock SOWP will be prepared after review by affected stakeholders and resolution of comments.

\subsection{PROPOSED GROUND WATER COMPLIANCE STRATEGIES}

There are two proposed ground water compliance strategies for the Shiprock site corresponding to two distinct, interconnected ground water systems: the terrace system and the floodplain system. The proposed ground water compliance strategy for the terrace system is no remediation. This strategy is based on the application of supplemental standards because the ground water can be classified as limited-use ground water (aquifer yield is less than 150 gallons [gal] [570 liters [L]] per day, 40 CFR $\$ 192.11$ (e)) and there is no human health or environmental risk of applying supplemental standards. The proposed ground water compliance strategy for the floodplain system is active ground water 
remediation. There are 19 constituents of concern (COC) within the floodplain aquifer. Active ground water remediation is proposed to attain background concentration levels or the EPA's maximum concentration limits (MCL) as proposed for the UMTRA Project.

\subsection{RELATIONSHIP TO PROGRAMMATIC UMTRA GROUND WATER DOCUMENTS}

Programmatic documents that provide guidance for the SOWP include the UMTRA Groundwater Project Plan (GWPP) (DOE, 1992), the Programmatic Environmental Impact Statement for the Uranium Mill Tailings Remedial Action Ground Water Project (PEIS) (DOE, 1994a), and the Technical Approach to Groundwater Restoration (TAGR) (DOE, 1993). The GWPP states the mission, need, and objectives for the UMTRA Ground Water Project and provides an overall technical and management approach for conducting the Ground Water Project. The PEIS provides an objective programmatic decision-making framework for conducting the UMTRA Ground Water Project, assesses the potential programmatic impacts of conducting the Project, provides a framework for determining the site-specific ground water compliance strategies, and provides data and information that can be used to prepare site-specific environmental impact analyses more efficiently. The TAGR provides technical guidance for conducting the Ground Water Project. 


\subsection{REGULATORY FRAMEWORK}

This SOWP proposes two ground water compliance strategies for the Shiprock site to achieve compliance with the proposed EPA ground water standards applicable to Title I UMTRA Project processing sites. This section identifies the relationship of the Uranium Mill Tailings Radiation Control Act (UMTRCA), the proposed EPA compliance standards, the cooperative agreements, and the National Environmental Policy Act (NEPA) to the UMTRA Ground Water Project.

\subsection{URANIUM MILL TAILINGS RADIATION CONTROL ACT}

The U.S. Congress passed the UMTRCA (42 USC $\$ 7901$ et seq.) in 1978 in response to public concerns about the potential health hazards from exposure to uranium mill tailings over long periods of time. The UMTRCA authorized the DOE to stabilize, dispose of, and control uranium mill tailings and other contaminated materials at uranium mill processing sites.

The UMTRCA has three titles that apply to uranium processing sites. Title I of the Act designates 24 inactive processing sites that will undergo remediation; directs the EPA to promulgate standards; mandates remedial action in accordance with standards prescribed by the EPA; directs the U.S. Nuclear Regulatory Commission (NRC), states, and Indian tribes to concur in the remedial actions; directs the NRC to license the disposal sites for long-term care; and directs the DOE to enter into cooperative agreements with the affected states and Indian tribes. Title II applies to active uranium mills, and Title III applies to certain uranium mills in New Mexico. The UMTRA Project has responsibility for administering only Title I of the UMTRCA.

In 1988, Congress amended the UMTRCA Amendments Act (Amendments Act; 42 USC §7923), authorizing the DOE to extend without limitation the time needed to complete ground water remediation activities at the processing sites. Section 108 of the UMTRCA requires that the DOE comply with the proposed EPA standards (40 CFR Part 192 (1994)) in the absence of final standards.

\subsubsection{Environmental Protection Agency ground water compliance standards}

The UMTRCA requires that the EPA promulgate standards for protecting human health and the environment from hazardous constituents associated with the processing of uranium and the resulting residual radioactive materials (RRM). On January 5, 1983, the EPA published standards (40 CFR part 192 (1994)) for the disposal and cleanup of RRMs. The EPA proposed new standards (52 FR 36000 (1987)) in response to remanded sections.

The proposed standards address two ground water contamination scenarios. The first addresses future ground water contamination that may occur from tailings piles after disposal; the second addresses the cleanup of contamination that occurred at the processing sites before disposal of the tailings piles (52 FR 
36000 (1987)). Protection of the ground water at the disposal sites is being addressed in the UMTRA Surface Project. The UMTRA Ground Water Project addresses the contamination that occurred at the processing sites before the surface remedial action was completed and is regulated by Subparts $B$ and $C$ of the proposed standards.

Subpart B, "Standards for Cleanup of Land and Buildings Contaminated with Residual Radioactive Materials from Inactive Uranium Processing Sites" (52 FR 36007 (1987)/ requires that remedial action at processing sites be conducted to ensure that the amounts of RRMs in ground water meet any one of three criteria specified:

- Background levels - concentrations of constituents in nearby ground water that were not affected by processing activities.

- Maximum concentration limits (MCL) - the EPA's maximum limits for concentrations of certain hazardous constituents in ground water, as proposed for the UMTRA Project. The MCLs for inorganic constituents that apply to UMTRA Project sites are given in Table 2.1 .

- Alternate concentration limits $(A C L)$ - alternate limits for hazardous constituents that do not pose a substantial present or potential hazard to human health or the environment, as long as the limit is not exceeded.

Under certain specific conditions, the DOE may apply supplemental standards to contaminated ground water in lieu of background levels, MCLs, or ACLs (52 FR 36000 (1987)). Supplemental standards may be applied if any one of the following conditions is met:

- Remedial actions necessary to implement Subpart A or B would pose a significant risk to workers or members of the public.

- Remedial actions to meet the standards would directly produce environmental harm that is clearly excessive compared to the health benefits of remediation to persons living on or near the sites, now or in the future.

- The estimated cost of remedial action is unreasonably high relative to the long-term benefits, and the RRMs do not pose a clear present or future hazard.

- There is no known remedial action.

- The remediation of ground water quality at any processing site is technically impracticable from an engineering standpoint.

- The ground water is classified as limited-use (Class III) ground water. Subpart B of the proposed standards defines limited-use ground water as 
Table 2.1 Maximum concentrations of inorganic constituents for ground water protection at UMTRA Project sites ${ }^{a}$

\begin{tabular}{|c|c|}
\hline Constituent & $M C L^{b}$ \\
\hline Arsenic & 0.05 \\
\hline Barium & 1.0 \\
\hline Cadmium & 0.01 \\
\hline Chromium & 0.05 \\
\hline Lead & 0.05 \\
\hline Mercury & 0.002 \\
\hline Molybdenum & 0.1 \\
\hline Nitrate (as N) & $10.0^{\mathrm{C}}$ \\
\hline Selenium & 0.01 \\
\hline Silver & 0.05 \\
\hline Combined radium-226 and radium-228 & $5 \mathrm{pCi} / \mathrm{L}$ \\
\hline Combined uranium-234 and uranium-238 & $30 \mathrm{pCi} / \mathrm{L}^{\mathrm{d}}$ \\
\hline $\begin{array}{l}\text { Gross alpha-particle activity } \\
\text { (excluding radon and uranium) }\end{array}$ & $15 \mathrm{pCi} / \mathrm{L}$ \\
\hline
\end{tabular}

$a_{40}$ CFR \$264.94 (1994), 52 FR 36007 (1987).

bMilligrams per liter (mg/L) unless otherwise noted.

$\mathrm{C}_{\text {Equivalent to }} 44 \mathrm{mg} / \mathrm{L}$ nitrate as nitrate.

${ }^{d}$ Equivalent to $0.044 \mathrm{mg} / \mathrm{L}$.

pCi/L - picocuries pr liter. 
ground water that is not a current or potential source of drinking water because total dissolved solids (TDS) exceed 10,000 milligrams per liter $(\mathrm{mg} / \mathrm{L})$; there is widespread ambient contamination that cannot be cleaned up using treatment methods reasonably employed in public water supply systems; or the quantity of water available is less than 150 gal $(570 \mathrm{~L})$ per day (40 CFR \$192.11(e)). When limited-use ground water applies, supplemental standards shall ensure that current and reasonably projected uses of the ground water are preserved (EPA, 1994).

- Radiation from radionuclides other than radium-226 and its decay products is present in sufficient quantity and concentration to constitute a significant radiation hazard from RRMs.

Subpart B also provides for selecting natural flushing as a means to meet the proposed standards. Natural flushing means allowing natural ground water processes to reduce the contamination in ground water to the standards (background levels, MCLs, or ACLs). Natural flushing must allow the standards to be met within 100 years. In addition, ground water must not be currently, or projected to become, a source of drinking water during the period of natural flushing. Institutional controls (measures that restrict access to contamination, protect human health, and satisfy beneficial uses of ground water) must be established and maintained during the period of natural flushing.

Subpart C "Implementation," provides guidance for implementing methods and procedures to provide reasonable assurance that the provisions of Subpart $B$ are satisfied. Subpart $C$ requires that the conditions of Subpart $B$ be met on a sitespecific basis, using information gathered from site characterization and monitoring. Subpart $C$ also requires that the plan meet the conditions of Subpart $B$ as stated in the compliance strategy plan or remedial action plan (RAP) that contains the compliance strategy, a demonstration of effectiveness, and a monitoring program.

\subsubsection{Cooperative agreements}

The UMTRCA requires that remedial action be accomplished with the full participation of the affected states and Indian tribes on whose lands the uranium mill tailings are located. The UMTRCA also directed the DOE to enter into cooperative agreements with the states and Indian tribes.

\subsection{NATIONAL ENVIRONMENTAL POLICY ACT}

Implementation of the UMTRCA represents a major federal action subject to the requirements of the NEPA of 1969 (42 USC $\$ 4321$ et seq.). The Council on Environmental Quality's regulations that implement the NEPA are codified in 40 CFR Part 1500-1508 (1994). The regulations require that each federal agency develop its own implementing procedures (40 CFR \$1507.3 (1994)). The DOE NEPA regulations are contained in "National Environmental Policy Act Implementing Procedures" (10 CFR Part 1021 (1994)). DOE guidance is 
provided in Recommendations for the Preparation of Environmental Assessments and Environmental Impact Statements (DOE, 1993b).

Pursuant to the NEPA, the DOE drafted a PEIS in 1994 for the UMTRA Ground Water Project to analyze potential impacts of implementing four programmatic alternatives for conducting ground water compliance at the UMTRA Project processing sites. The preferred alternative will be selected by the DOE and published in a record of decision. All subsequent actions on the UMTRA Ground Water Project must comply with this record of decision.

The environmental impacts from implementing the proposed compliance strategies presented in the final Shiprock SOWP will be addressed in an environmental assessment (EA) that will meet the requirements of the NEPA and tier off applicable issues discussed in the PEIS. 


\subsection{SUMMARY OF SITE CONDITIONS}

\subsection{SITE HISTORY}

\subsubsection{Location}

The Shiprock site is located on the Navajo Indian reservation east of U.S. Highway 666 and south of U.S. Highway 64 , and 1 mile (mi) (1.6 kilometers $[\mathrm{km}])$ south of the town of Shiprock, San Juan County, in northwest New Mexico. Farmington, New Mexico, is approximately $30 \mathrm{mi}(50 \mathrm{~km})$ east of the Shiprock site (Figure 3.1).

The former Shiprock mill site and disposal cell are located on top of a river terrace south and west of the San Juan River (Figure 3.2). The terrace is relatively level, with elevation ranging from a high of approximately 4980 feet (ft) (1520 meters [m]) above mean sea level (MSL) along the southwestern edge of the property to a low of about $4950 \mathrm{ft}(1510 \mathrm{~m})$ at the escarpment. A 50-ft $(15-m)$ high, northwest-southeast trending escarpment separates the terrace from a floodplain situated along the west bank of the San Juan River. The San Juan River flows in a northwesterly direction past the floodplain. Southwest of the site, the terrace slopes gently upward for approximately $2500 \mathrm{ft}(760 \mathrm{~m})$ where it meets the upland area.

The floodplain of the San Juan River is located at the base of the escarpment east and north of the completed uranium mill tailings disposal cell. It begins approximately $1000 \mathrm{ft}(300 \mathrm{~m})$ upstream of the former mill site, widens to about $1500 \mathrm{ft}(460 \mathrm{~m})$, then pinches out against the escarpment at the point where the San Juan River passes under the U.S. Highway 666 bridge approximately $2200 \mathrm{ft}(670 \mathrm{~m})$ downstream of the northwestern corner of the former mill site. Because the only practical access to the cliffs is from the floodplain, any environmental considerations associated with the escarpment are included with the floodplain for the purposes of this document.

Two arroyos are located east and west of the tailings site. Bob Lee Wash is an arroyo bordering the western side of the site. Many Devils Wash parallels Bob Lee Wash approximately $2500 \mathrm{ft}(760 \mathrm{~m})$ southeast of the site.

\subsubsection{Land and water use}

Shiprock had a reported population of 7687 in 1990 (DOC, 1990). A mix of residential and commercial development exists near the site. A U.S. Public Health Service building, Navajo Engineering and Construction Authority (NECA) facilities, Abandoned Mine Land Program office buildings, and fairgrounds are immediately west of the former mill site. West of U.S. Highway 666 is a residential area with a day care center and community development offices. A residential area is located northwest of Bob Lee Wash. In addition, approximately 10 households are located southwest of the disposal site. Some 


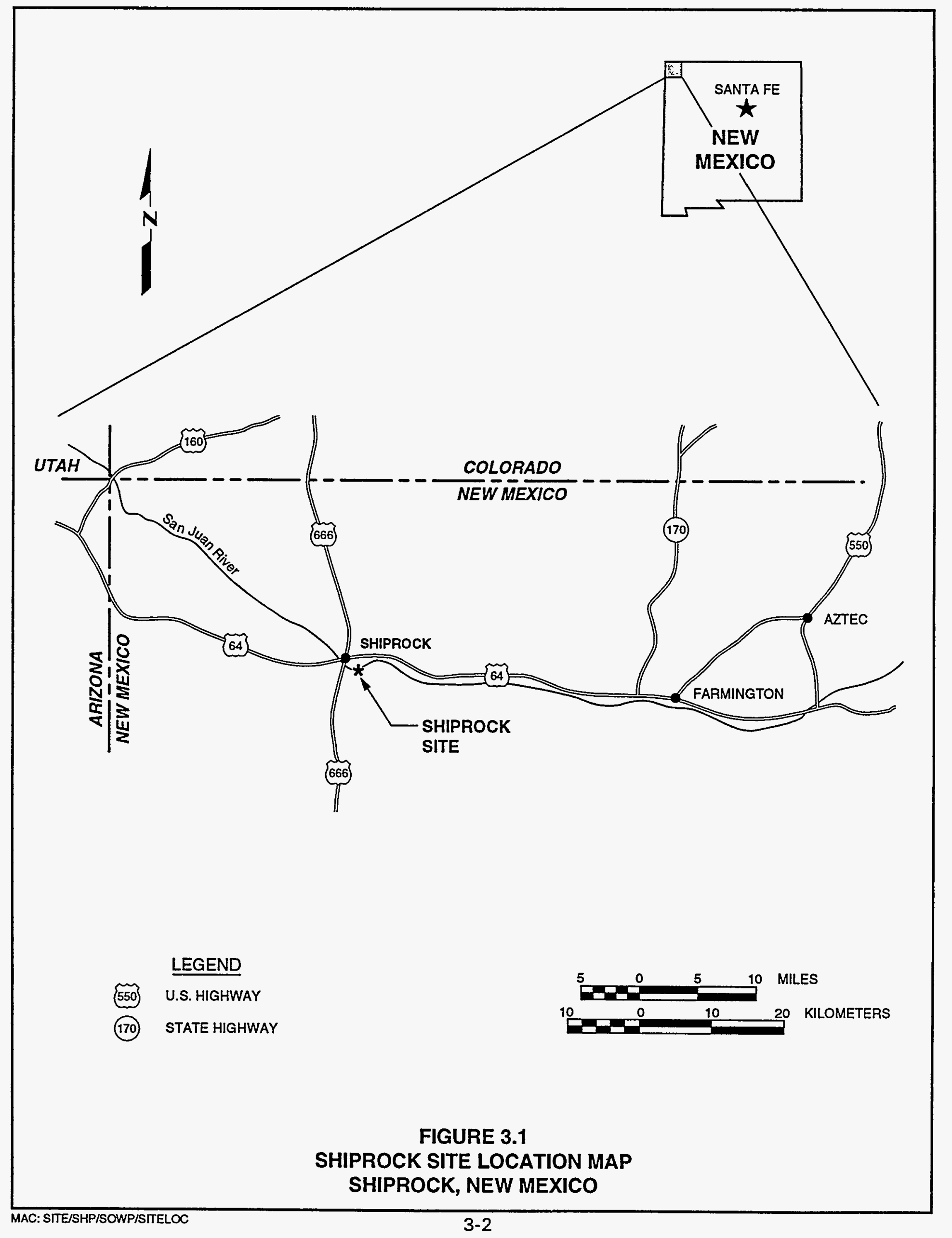




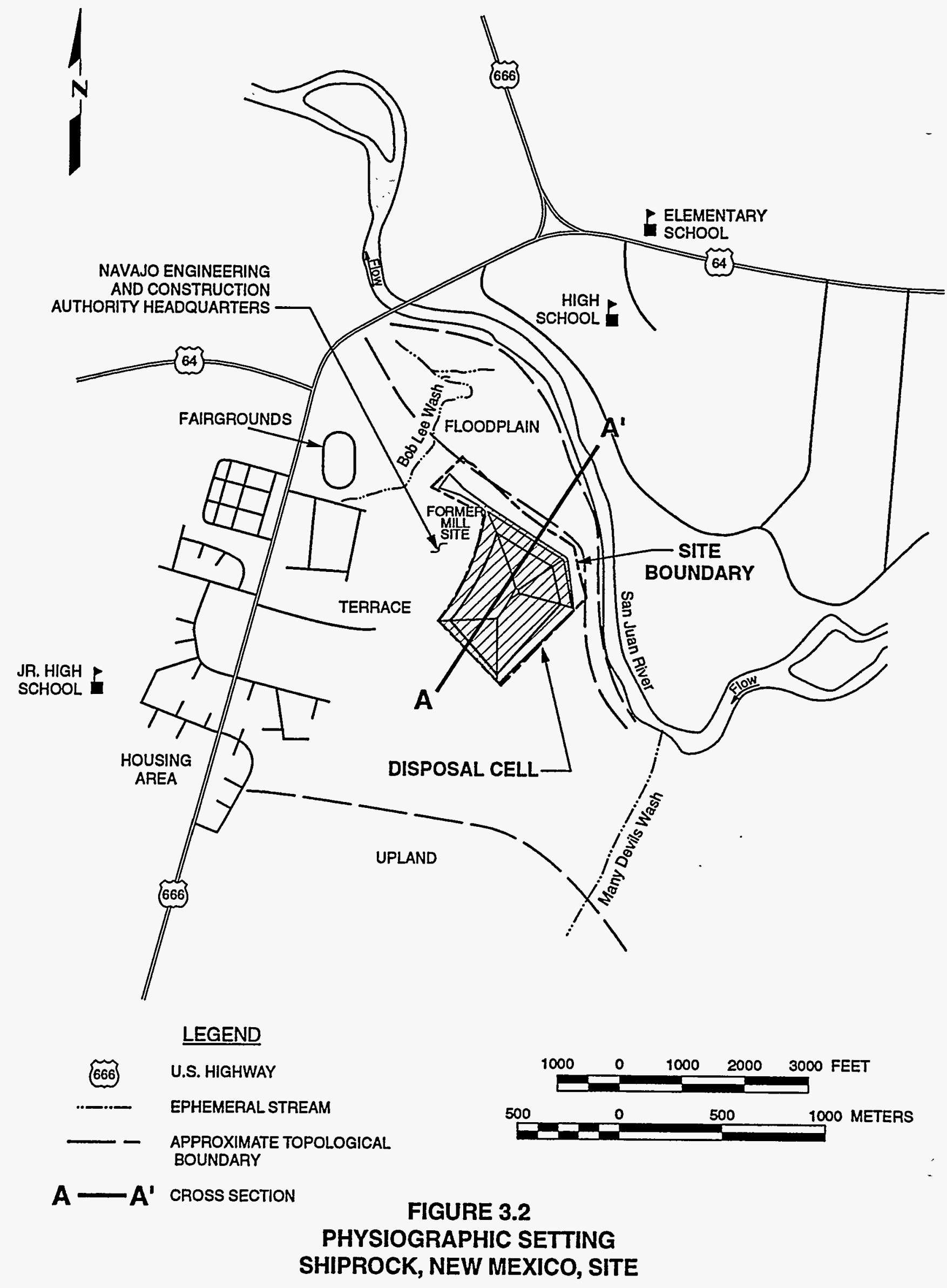


livestock and domestic animals are raised by these individual households near the site. A grazing permit has been issued for the floodplain below the site by the Bureau of Indian Affairs (BIA), although access to the floodplain is prevented by a fence where Bob Lee Wash opens onto the floodplain.

No domestic or other wells completed in the alluvium on the southwest side of the river near the site were identified in a field search in 1993. Treated San Juan River water is provided by the Navajo Tribal Utility Authority (NTUA) to these residences as well as the facilities and buildings described above. One NTUA water supply intake is located on the northeast side of the river $300 \mathrm{ft}$ $(90 \mathrm{~m})$ upstream of the U.S. Highway 666 bridge over the San Juan River. The intake structure is visible from the floodplain across the river. Pumps for this intake are installed approximately $15 \mathrm{ft}(5 \mathrm{~m})$ below the river surface. An infiltration gallery that may be related to this intake structure includes a $300-\mathrm{ft}$, 6 -inch $(90-\mathrm{m}, 15-\mathrm{cm})$ diameter transit pipe. The pipe runs under the river and may extend somewhat into the floodplain (Public Health Service, 1962). It is uncertain if the transit pipe is still in service as part of the intake gallery. Approximately 30 percent of the NTUA's water that is treated is drawn from this intake point.

\subsubsection{History of operations}

The former Navajo Mill at the Shiprock site was constructed and operated from 1954 to 1963 by Kerr-McGee Oil Industries, Inc., and from 1963 to 1968 by Vanadium Corporation of America and its successor, Foote Mineral Company. Before and during the milling operations, the site was leased from the Navajo Nation. When the lease expired in 1973, ownership of the site reverted to the Navajo Nation.

The mill reportedly processed approximately 1.5 million short tons $(1.4$ million metric tons) of ore along with smaller quantities of bulk precipitates from heap leach operations from the Monument Valley area and from purchased vanadium liquor (DOE, 1985). Ore processing consisted of crushing, leaching with sulfuric acid, washing, and extracting uranium and vanadium with organic solvents (di[2-ethylhexyl] phosphoric acid and tributyl phosphate in kerosene). Both nitrate and ammonium complexes were used as ion exchange strippers to concentrate the uranium, and ammonia was used to adjust the $\mathrm{pH}$ of the slurry during the milling process. Tailings from the washing circuit and yellow cake. filtrates were pumped to tailings disposal areas. Raffinate (the fluid remaining after the uranium has been removed from the process water) was allowed to evaporate in separate unlined ponds to the west and southeast of the tailings piles (Figure 3.3).

An average of 400 to 500 tons of ore were processed daily using the acid leaching process between 1954 and 1963 when Kerr-McGee operated the mill. From 1963 to 1968, the heap leaching operations were also conducted at the mill (Merritt, 1971). Water for the mill and plant operation was taken from the San Juan River just upstream of the mill. Kerr-McGee had two water 


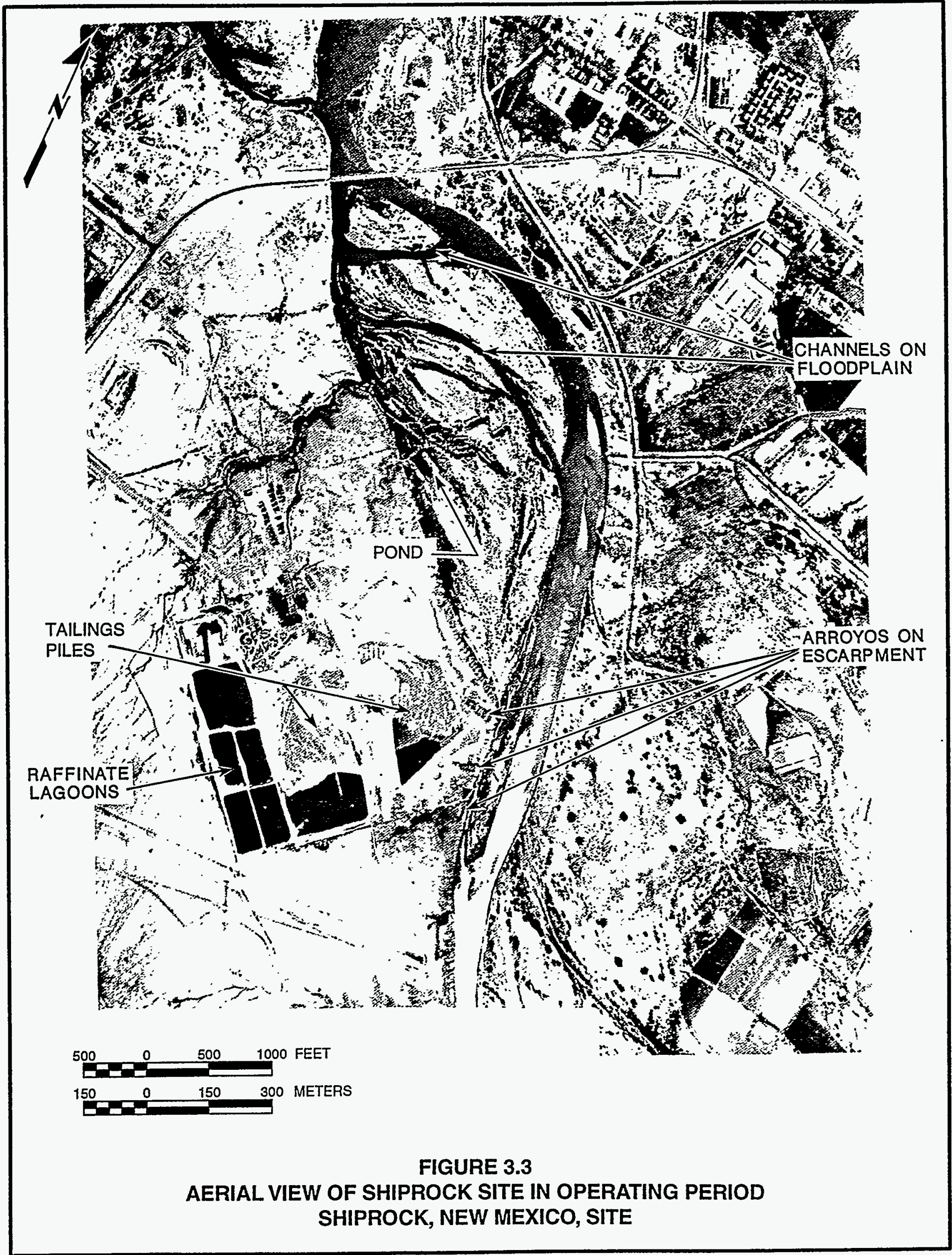


withdrawal permits, NM 2807 and NM 2875, for 500 and 700 acre-feet per year respectively.

An order of magnitude estimate has been made of water use and disposal. For the acid leach process, water use was approximately 3 to 5 tons of water per ton of ore processed, or approximately 270 gallons per minute $(\mathrm{gpm})$ (1022 liters per minute [L/min]) (based on 400 tons per day of ore processed and 4 tons of water used per ton of ore processed) (Merritt, 1971). All process water and slimes were discharged to unlined ponds. These ponds were used for evaporation and allowed the water to percolate into the underlying soil and rock beneath the ponds. In addition, the mill cooling water, approximately $130 \mathrm{gpm}$, was piped to a separate pond that discharged to Bob Lee Wash on the west side of the mill (Public Health Survey, 1962). The cooling water was at times contaminated due to overflow of contaminated process waters. The total water flow estimate is approximately $400 \mathrm{gpm}$ ( 645 acre-feet per year), or 54 percent of the Kerr-McGee surface water flow rights. A pond of unknown purpose was situated on the floodplain during the operation of the mill (Figure 3.3).

The mill had approximately 20 acres (ac) ( 8 hectares [ha]) of ponds for storing, evaporating, and percolation of the process water. Water that did not evaporate was allowed to percolate through the pond bottoms to the ground water below. The yearly average net evaporation rate (pan evaporation less rainfall) for the Shiprock site is approximately 65 inches per year, or $5.4 \mathrm{ft}$ per year (DOE, 1984).

A flow rate of $270 \mathrm{gpm}$ is equivalent to 1.19 acre-feet per day, or 435 acre-feet per year. With a net evaporation rate of 5.4 feet per year, and 20 ac ( $8 \mathrm{ha}$ ) of ponds, an average of 108 acre-feet of water could have been evaporated per year, or approximately $72 \mathrm{gpm}$. A 1960 Atomic Energy Commission (AEC) document (AEC, 1960), estimated that approximately $162 \mathrm{gpm}$, or 60 percent of the estimated $270 \mathrm{gpm}$ process water discharged to the ponds, seeped out of the bottom of the ponds. Together, the estimate of evaporation losses of $72 \mathrm{gpm}$ and the estimated $162 \mathrm{gpm}$ seepage losses account for $234 \mathrm{gpm}$, close to the $270 \mathrm{gpm}$ of process water estimated to have been used at the plant.

In 1960, seepage from various seeps on the escarpment in the area of the mill site ranged from 0.5 to $20 \mathrm{gpm}$ and totaled approximately $50 \mathrm{gpm}$ (Public Health Service, 1962). Based on the AEC estimate of $162 \mathrm{gpm}$ pond seepage losses less the Public Health Service estimate of $50 \mathrm{gpm}$ seepage that reached land surface, approximately $112 \mathrm{gpm}$ remained in the underlying rock. Between 1954 and 1968, this $112 \mathrm{gpm}$ totals approximately 2500 acre-feet (180 acre-feet per year), if the quantities were relatively constant over this time period.

No data have been found on the water quality in the evaporation ponds except that the water pumped to the ponds was at a pH of 2 (Public Health Service, 1962). A limited amount of water quality data was obtained in 1960 from the seeps and from Bob Lee Wash. A 1960 Public Health Service study indicated 
that cooling water radioactivity levels measured in Bob Lee Wash were comparable to radioactivity levels measured in the evaporation ponds, but the cooling water showed lower values for TDS (Public Health Service, 1962). The water in Bob Lee Wash, when sampled in 1960, may have been high in TDS due to the dissolution of solids deposited in the wash when a pond embankment failed that summer. The cooling water subsequently sampled in the wash was high in TDS due to the dissolution of these solids.

The seeps sampled nearest the ponds had the highest chemical concentrations. TDS was not measured, but sulfates of $3900 \mathrm{mg} / \mathrm{L}$ were observed along with total hardness (as calcium carbonate) of $10,800 \mathrm{mg} / \mathrm{L}$; nitrate concentrations of 1400 to $1600 \mathrm{mg} / \mathrm{L}$; and estimates of TDS of 9,000 to $12,000 \mathrm{mg} / \mathrm{L}$. The water quality from the seeps varied in quality, with these being among the highest values found.

\subsubsection{Surface remedial action and ground water protection strategy}

Between 1984 and 1986, the tailings were stabilized permanently on the site by consolidating the tailings and associated contaminated soils into a recontoured pile. The final cover at Shiprock consists of a 7-ft $(2-\mathrm{m})$ thick compacted clay layer that serves as a barrier to radon emanation and water infiltration. The clay layer is covered with a riprap cap designed to provide erosion protection for the effective life of the cell, up to 1000 years (DOE, 1985). The disposal cell covers about 76 ac ( $31 \mathrm{ha})$ (Thiers, 1986). A security fence encloses the embankment. No ground water protection strategy was determined for the Shiprock disposal site because the RAP was agreed to prior to the proposed EPA ground water standards (52 FR 36000 (1987)).

\subsection{SOURCES OF EXISTING DATA}

Beginning in 1982 and continuing to the present, surface and ground water characterization studies have been conducted at the processing site by the following contractors: Ford, Bacon, \& Davis, Inc. (FBDU, 1981); Geochemistry and Environmental Chemistry Research, Inc. (GECR, 1982); Dames and Moore (1982); Colorado State University (CSU, 1982); and the current DOE Technical Assistance Contractor (TAC), Jacobs Engineering Group Inc. Approximately 60 monitor wells have been installed and sampled on and around the site throughout the history of characterization. Some of these monitor wells have been abandoned, and many others were not constructed to collect the ground water and hydrologic data needed to support the proposal of remedial strategies. Surface water and sediment samples were taken from the San Juan River upstream, downstream, and adjacent to the site. The above references, sitespecific data sets, and all TAC documents are on file in the UMTRA Project Document Control Center in Albuquerque, New Mexico. Much of the data referred to in this document will be included in Revision 1 of the SOWP along with the data being proposed for collection. 
The conceptual site model summarizes the effects of milling activities on the environment, the properties of the aquifer, general geology, ground water sources and sinks, and transport processes that take place in the aquifer near the site. This model identifies site-specific information and data gaps so that compliance strategies may be clearly identified, remediation methods proposed, and additional data collection efforts defined to substantiate the proposed compliance strategies.

\subsubsection{Hydrogeologic setting}

The Shiprock site consists of two distinct, interconnected hydrogeologic systems (Figure 3.4). These two systems, the terrace and the floodplain, are characterized by similar lithologies, but contrasting ground water flow systems and contaminant distributions.

\section{Regional hydrogeologic setting}

Because of low precipitation amounts and high evaporation rates in the region, very little recharge to unconfined shallow aquifers occurs from surface precipitation events (DOE, 1991; NMBMMR, 1983). Rainfall averages 6.4 inches $(16 \mathrm{~cm})$ per year, and pan evaporation rates have been measured at an average annual rate of 65 inches $(165 \mathrm{~cm})$ per year (DOE, 1984). Unconfined shallow aquifers within the hydrogeologic region of the site exist primarily due to recharge from rivers. Natural recharge to the terrace system is entirely from precipitation and the floodplain system is recharged primarily by the San Juan River.

In general, the geologic profile of the region consists of alluvial deposits of Quaternary age. The alluvial deposits overlie Cretaceous age Mancos Shale. Underlying the Mancos Shale is the Cretaceous age Dakota Sandstone and the Jurassic age Morrison Formation.

Ground water occurs under confining conditions in the Dakota Sandstone and Morrison Formation. A flowing artesian well constructed in 1955 near the site is reportedly completed in the Morrison Formation from approximately 1500 to $1900 \mathrm{ft}(450$ to $570 \mathrm{~m}$ ) below land surface (McLean and Johnson, 1987). The free-flowing condition (approximately $60 \mathrm{gpm}$ ) demonstrates that the piezometric surface in the Morrison Formation is higher than the water table in the terrace or floodplain aquifers. This higher pressure head, combined with confinement of the aquifer by the Mancos Shale, will preclude movement of impacted water beneath the disposal cell into the deeper aquifers. This flowing well is discharging into Bob Lee Wash. 

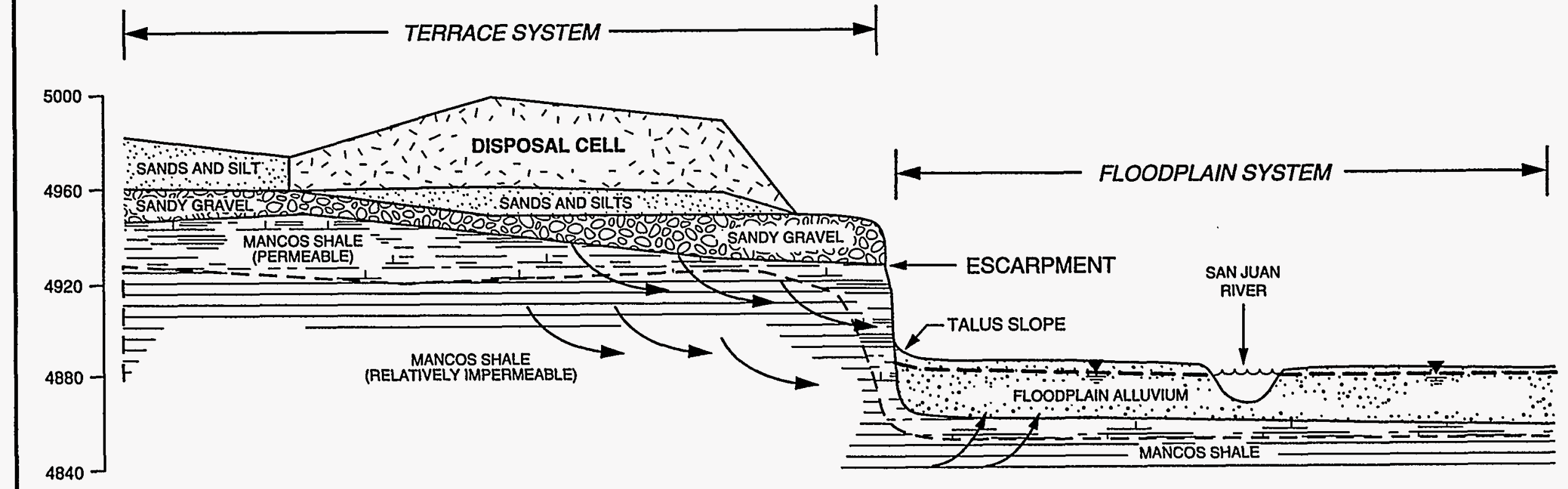

$\omega$ ELEVATION

6. IN FEET

(MSL)

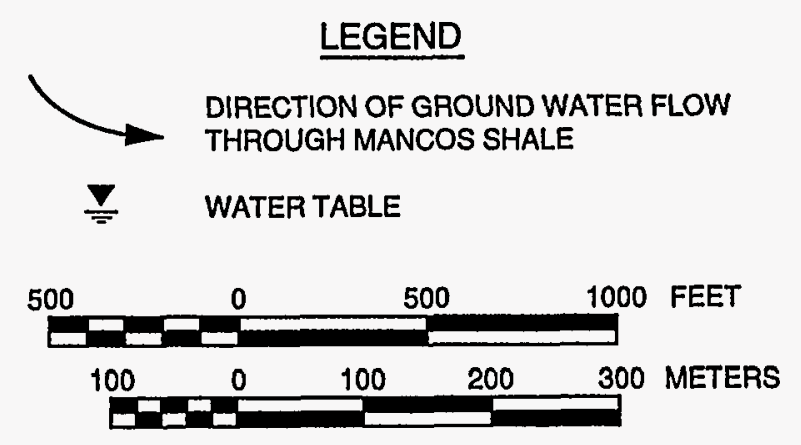

FIGURE 3.4

GENERALIZED CROSS SECTION A-A' SHIPROCK, NEW MEXICO, SITE 


\section{Terrace hydrogeologic system}

The terrace hydrogeologic system comprises the following components:

- Prior to milling operations, an insignificant perched ground water system most likely existed along an alluvium-Mancos Shale interface within the elevated terrace. Based on the climatic data mentioned above, this system receives a negligible amount of recharge from direct precipitation.

- As a result of milling operations, an estimated 840 million gal (3200 million $L$ ) of water was discharged into the terrace system, producing a significant ground water mound above the alluvium-Mancos Shale interface underlying the former mill site.

- Water in the ground water mound could have flowed away from the mound in a radial pattern when the mound was high during active use of the ponds on the terrace. As the mound diminished with the mill closing, ground water flow from the mound would have been primarily limited to the west and northwest along the direction of dip of the top of the Mancos Shale, and toward the floodplain through fractures in the Mancos Shale.

- Currently, it appears that water in the terrace aquifer discharges primarily to the floodplain system through seeps on the escarpment and fractures in the Mancos Shale, and that this flow is less now than it was at the peak of the mill operations. This flow is expected to diminish further, because the only recharge to the terrace aquifer is from precipitation.

The terrace hydrogeologic system components are supported by the detailed discussion below.

The elevated terrace at the Shiprock site is capped by alluvial deposits of Quaternary age ranging in thickness from 10 to $45 \mathrm{ft}(3$ to $13 \mathrm{~m})$. These deposits consist of interbedded sands and silts with numerous lenses of gravel and cobbles. The alluvial terrace deposits overlie the Cretaceous age Mancos Shale (Figure 3.4).

The Mancos Shale in the vicinity of the Shiprock site typically consists of horizontally bedded shales and sandy shales and is approximately $1000 \mathrm{ft}$ $(300 \mathrm{~m})$ thick. The upper 10 to $30 \mathrm{ft}(3$ to $9 \mathrm{~m})$ of the Mancos Shale is highly weathered and fractured with low strength. Below this weathered zone, the shale is more competent and relatively impermeable.

The upper surface of the Mancos Shale exhibits erosional effects from the ancestral San Juan River. A structure map of the top of the Mancos Shale (Figure 3.5) shows erosional swales and ridges characteristic of meandering fluvial systems. These swales (paleochannels) and ridges are oriented approximately east-west along the ancestral San Juan River drainage underlying the disposal cell and former mill site. 


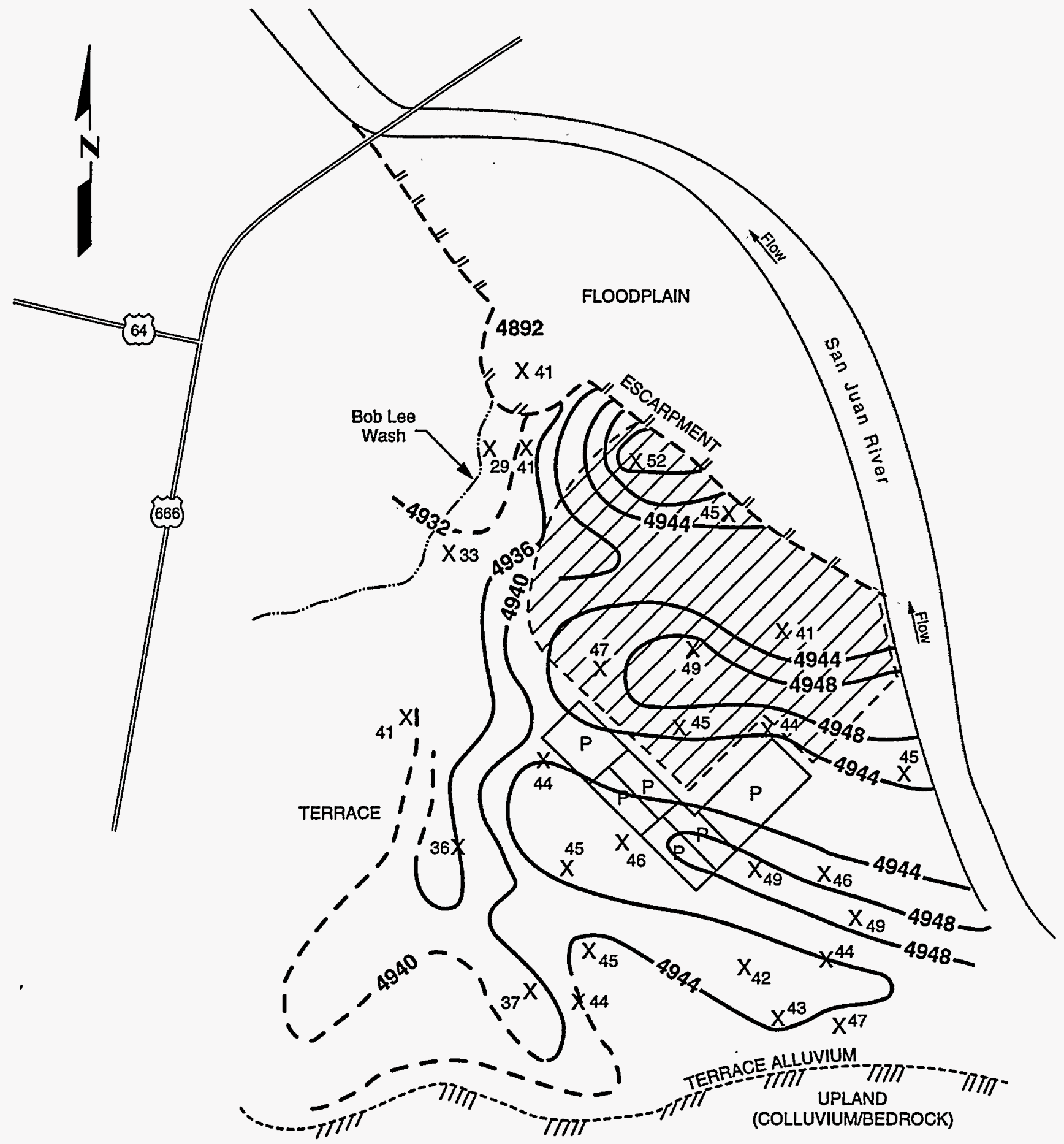

LEGEND

-4892 BEDROCK SURFACE CONTOUR (FEET MSL) (ESTIMATED FROM LIMITED DATA)

${ }^{41} \times \quad$ BEDROCK ELEVATION IN

UIJ) FORMER TAILINGS PILES AND MILLSITE

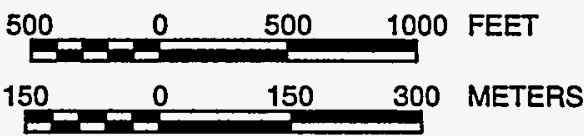

$P$ FORMER RAFFINATE POND

666 U.S. HIGHWAY

FIGURE 3.5

\section{BEDROCK SURFACE CONTOURS ON TERRACE SHIPROCK, NEW MEXICO, SITE}


The ground water in the alluvium and the upper part of the Mancos Shale is unconfined. Based on the low yield of ground water monitor wells on the terrace, there appears to be a very small amount of ground water within the terrace alluvium and in the upper, weathered part of the Mancos Shale.

Most of the water in the terrace alluvium in the site vicinity is believed to have been derived from the former milling operations and tailings piles. The ponds active during the milling operations (Figure 3.3 ) reportedly lost approximately 7 million gal (26 million L) per month (Gilkey and Stotelmeyer, 1965). Of this amount, 5 million gal (19 million $L$ ) per month of process water is estimated to have remained in the terrace formation (Public Health Service, 1962). This amount of water is likely to have formed a considerable ground water mound perched on the Mancos Shale. Seepage infiltrating the alluvium would move across the shale surface in all directions and infiltrate the upper, weathered zone of the Mancos. As the size of the mound diminished after the milling operations ceased, the movement of the perched ground water would be controlled for the most part by the erosional topography of the top of the Mancos Shale and by fractures in the Mancos Shale.

The erosional topography (Figure 3.5 ) would likely cause perched ground water, derived from the ground water mound, to flow west-northwest in addition to flowing north and northeast toward the San Juan River. The documentation of seeps on the escarpment during milling operations in the region where swales were truncated by the escarpment supports the theory of paleochannel control on contaminant migration.

Some of the ground water in the terrace alluvium may also percolate down into the upper, fractured part of the Mancos Shale. This water moves horizontally along bedding planes and can be seen seeping from bedding planes in the shale along the escarpment face immediately north of the disposal cell. It is likely that a small component of flow enters the deeper Mancos Shale and flows through fractures toward the San Juan River. This water then moves from the Mancos Shale into the overlying floodplain alluvium (Figure 3.4). Evidence of this discharge from the Mancos Shale into the alluvium has been observed in floodplain monitor wells completed in the Mancos Shale. Monitor wells in the Mancos Shale appear to show a higher pressure head relative to those completed in the overlying floodplain alluvium.

\section{Floodplain hydrogeologic system}

The floodplain hydrogeologic system comprises the following components:

- The recent alluvial materials of the floodplain system were deposited on an eroded Mancos Shale surface. The deposits are typical of floodplains in such environments. They vary from coarse gravel and cobbles found in high-energy channels, to fine uniform sands indicative of point bars, to silty sediments typical of quiet backwater areas. 
- The surface of the Mancos Shale underlying the floodplain deposits is characterized by parallel meander scars (scour channels) typical of a lateral migrating meander process. These scour channels are at lower elevation than the base of the San Juan River channel.

- The floodplain alluvium is characterized by sand and silt deposits with some gravel overlain by coarser-grained gravel and cobble deposits that contain some sand. The finer-grained deposits range in thickness from about 1 to $13 \mathrm{ft}(0.3$ to $4 \mathrm{~m})$. The coarser-grained deposits range in thickness from about 5 to $19 \mathrm{ft}(1.5$ to $6 \mathrm{~m})$. These deposits are cut by a series of recent meander scars.

- The primary source of ground water recharge to the floodplain system is from the San Juan River. Secondary sources include 1) the artesian well discharging to Bob Lee Wash, 2) escarpment seeps discharging from the upper weathered Mancos section of the terrace system (along bedding planes and fractures), 3) precipitation, and 4) possible fracture flow from the Mancos Shale beneath the floodplain alluvium.

- The lithologic and structural heterogeneity of the floodplain system suggests there are vertical and horizontal variations in the hydraulic conductivity of the system. Ground water flow paths and velocities would be affected by these variations.

- Structural depressions on the top of the Mancos Shale (the scour channels) produced by the lateral meander process may result in ground water that is stagnant relative to the ground water flow in the upper alluvium, which is unimpeded by the structural surface of the Mancos Shale. Higher density water (water with high TDS) would tend to settle in these depressions where flow velocities may be slower than that of the shallower ground water. Associated constituents in the high TDS water would also be trapped in these depressions.

The floodplain hydrogeologic conceptual model components are supported by the detailed discussion below.

North and east of the disposal cell is the floodplain system of the San Juan River (Figure 3.2). The floodplain consists of unconsolidated alluvial material ranging in size from cobbles to clay size particles. The Mancos Shale underlies the floodplain alluvium at an average depth of approximately $15 \mathrm{ft}(5 \mathrm{~m})$ (Figure 3.4). The floodplain deposits are limited in their areal extent. The deposits are bounded to the west and south by the 50-ft $(15-\mathrm{m})$ high Mancos Shale escarpment. The floodplain is bounded to the east and north by the San Juan River.

A structure map for the top of the Mancos Shale where it underlies the floodplain alluvial deposits is shown in Figure 3.6. Available data are restricted to the southern portion of the floodplain. The map depicts a series of ridges and 


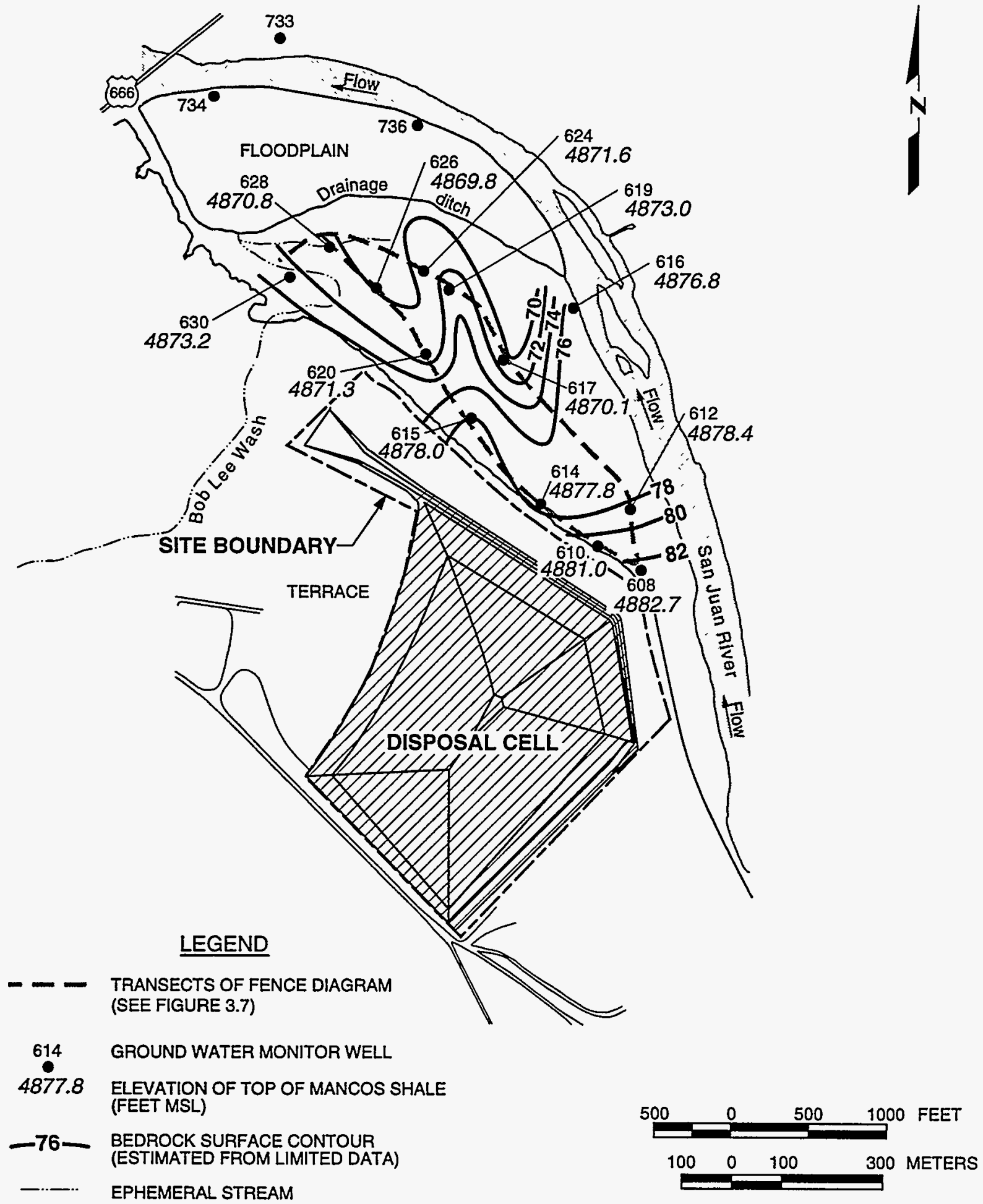

EPHEMERAL STREAM

666 U.S. HIGHWAY

FIGURE 3.6

BEDROCK SURFACE CONTOURS ON FLOODPLAIN SHIPROCK, NEW MEXICO, SITE 
swales, parallel to subparallel to the San Juan River. This morphology (parallel meander scars) is the typical result of the lateral meander migration process of the San Juan River.

Lithologic data from boreholes and monitor wells were used to define two distinct units within the recent alluvial deposits. They consist of an upper unit containing interbedded gravel to silty clays, and a lower, relatively coarsergrained, poorly sorted unit containing gravel to cobble size material. This reflects the characteristic sequence of grain size (fining upward) and sedimentary structures typically associated with a point bar sequence. Figure 3.7 is a fence diagram depicting in part the stratigraphic relationships within the floodplain deposits.

The floodplain contains a shallow unconfined ground water system. It is recharged primarily by water from the San Juan River that enters the floodplain at its upstream end, approximately $1000 \mathrm{ft}(300 \mathrm{~m})$ east of the tailings pile. Additional recharge comes from the flowing well at Bob Lee Wash, from the seeps along the escarpment, and from precipitation. The floodplain system is also thought to be a local discharge source for the underlying Mancos Shale. The ground water in the floodplain then discharges back to the river along the downstream half (northern end) of the floodplain. A water table map of the floodplain is shown in Figure 3.8.

Some ground water in the floodplain enters a drainage ditch that separates the northwestern third of the floodplain. This ditch follows a preexisting natural meander channel in the floodplain (Figure 3.3) but appears to have been artificially deepened. During periods of high river flow and/or heavy precipitation, the water table intersects this ditch. Some ground water flow is diverted into the ditch, which discharges to the river at the extreme northwestern end of the floodplain. During low river flow periods, however, the ditch is dry and the water table is beneath the bottom of the ditch.

Water level data from the river and from monitor wells on the floodplain near the river show that water levels between the river and the floodplain aquifer are very close. This indicates that there is a direct connection between water in the river and ground water in the floodplain aquifer, which suggests that it is unlikely that ground water flows from the aquifer on the southwest side of the river to the aquifer on the northeast side of the river. High rates of pumping in wells on the northeast side of the river could induce ground water flow to the northeast beneath the river.

Visual inspection of the alluvial deposits and comparisons with typical ranges of hydraulic conductivity described in the literature (Hunt, 1984) suggest that the hydraulic conductivity could vary by two orders of magnitude, from less than 5 feet per day ( $\mathrm{ft} /$ day) $(0.001$ centimeters per second $[\mathrm{cm} / \mathrm{s}]$ ) to more than $300 \mathrm{ft} /$ day $(0.1 \mathrm{~cm} / \mathrm{s})$. The sediments encountered during installation of monitor wells 734 and 736 (Figure 3.8), where ground water discharges from the floodplain into the San Juan River, were relatively uniform, medium-grained 


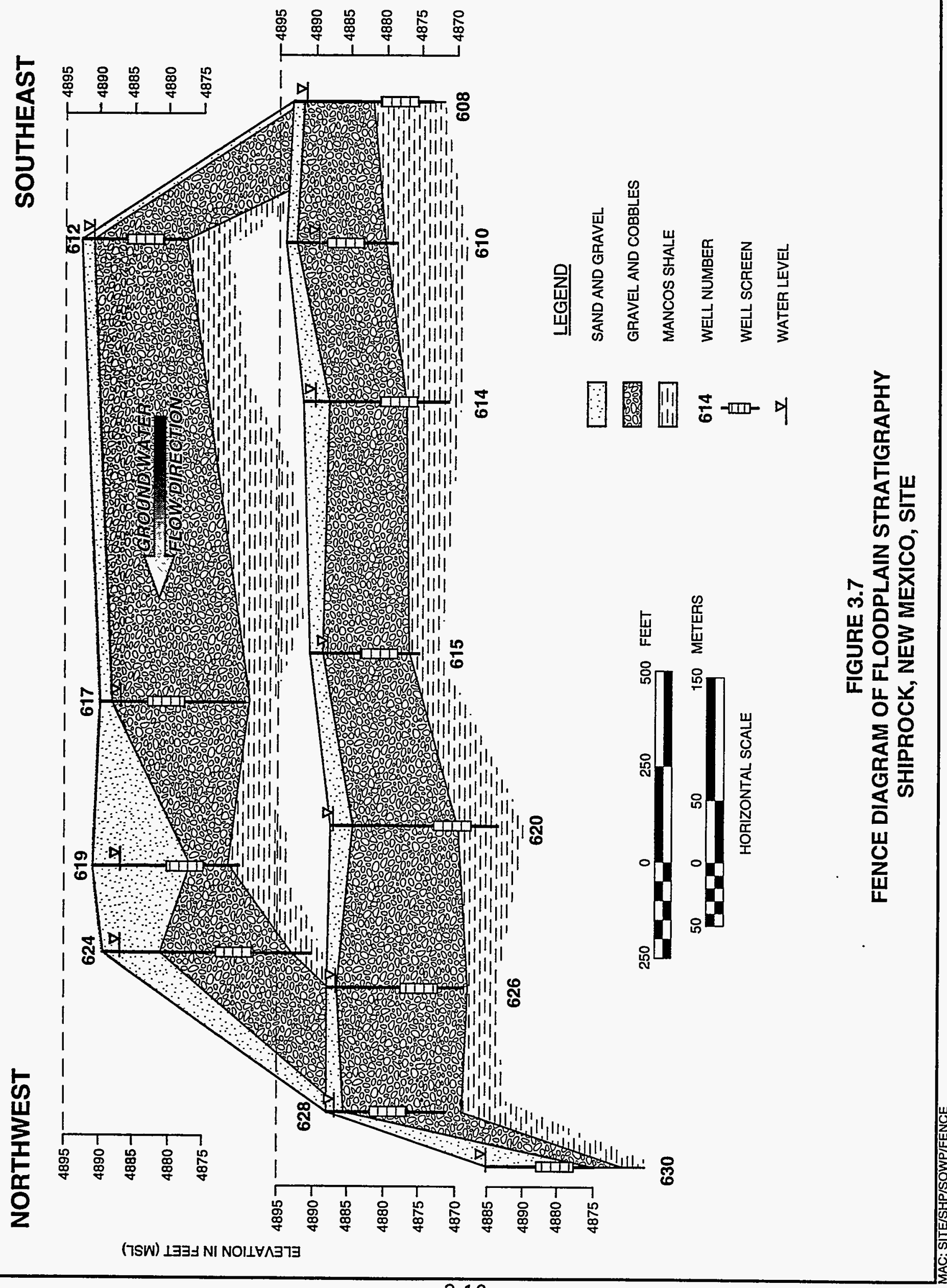




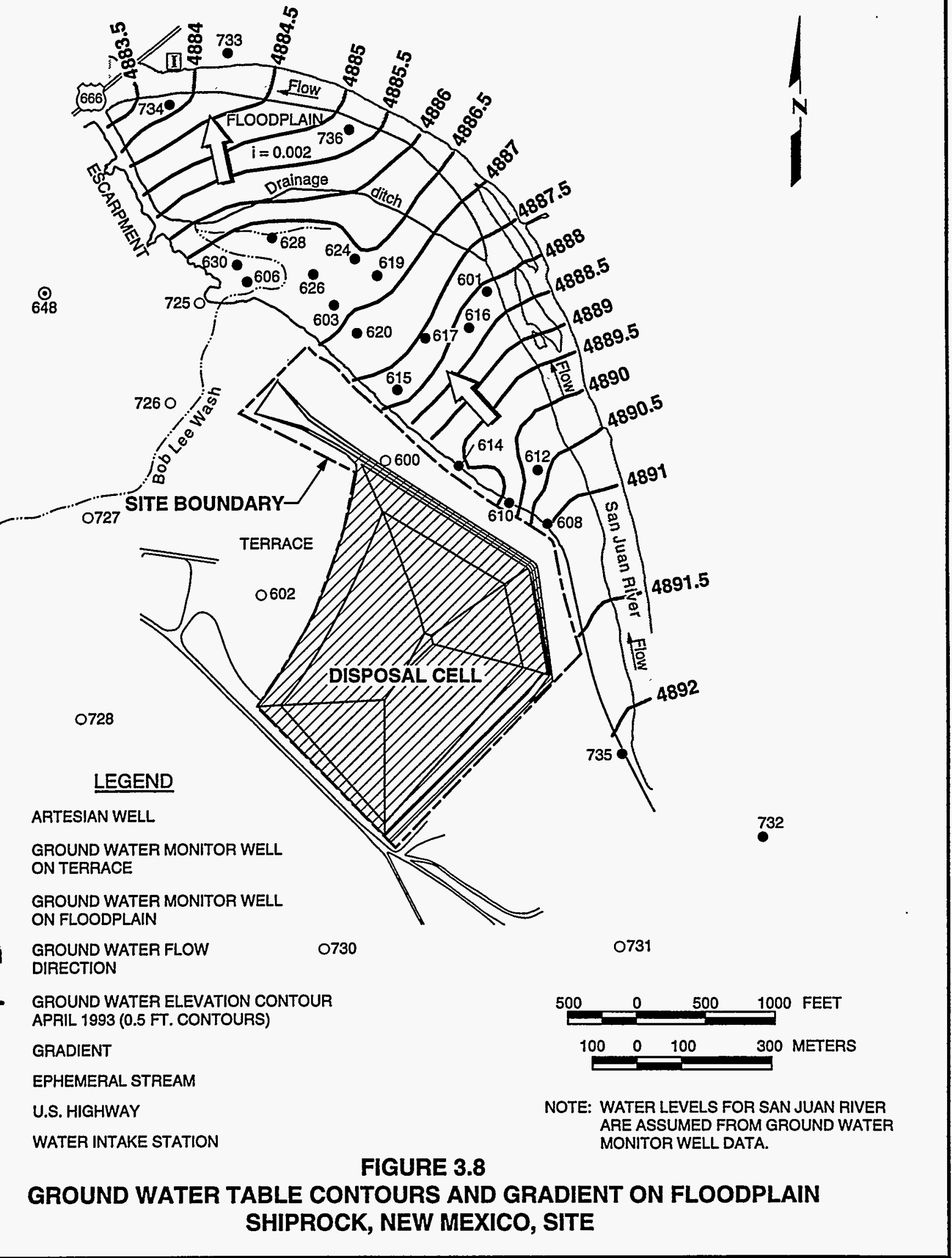


sands. Because the hydraulic conductivity of these sediments will control the discharge rate of impacted water to the San Juan River, an intermediate hydraulic conductivity typical of such sediments (approximately $30 \mathrm{ft} / \mathrm{day}$ $[0.01 \mathrm{~cm} / \mathrm{s}]$ ) (Freeze and Cherry, 1979) will be used in this study until further data-gathering efforts show otherwise. The hydraulic gradient across the floodplain is approximately 0.002 .

An average ground water discharge of about $7 \mathrm{gpm}(27 \mathrm{~L} / \mathrm{min})$ is calculated based on a hydraulic conductivity of $30 \mathrm{ft} /$ day $(0.01 \mathrm{~cm} / \mathrm{s})$, a hydraulic gradient of 0.002 , and an estimated cross-sectional area of discharge of about 20,000 square feet $\left(\mathrm{ft}^{2}\right)$ (1900 square meters $\left[\mathrm{m}^{2}\right]$ ) along the southern bank of the San Juan River. This cross-sectional area is based on a depth of the river of about $8 \mathrm{ft}(2.4 \mathrm{~m})$ and a length of $2500 \mathrm{ft}(750 \mathrm{~m})$ where the water level elevations show discharge from the floodplain aquifer to the river.

\section{Surface water}

The San Juan River forms the eastern and northern boundaries of the floodplain. Surface runoff from northwest and west of the disposal cell flows into Bob Lee Wash, which discharges onto the floodplain. Bob Lee Wash also receives a constant discharge of approximately $60 \mathrm{gmp}(230 \mathrm{~L} / \mathrm{min})$ from an artesian well (648) located west of the wash (Figure 3.9). Discharge from this well flows down Bob Lee Wash and discharges into a swampy area on the floodplain. This water eventually flows into a drainage channel that cuts across the floodplain and joins the San Juan River approximately $0.5 \mathrm{mi}(0.8 \mathrm{~km})$ northwest of the disposal cell. Surface runoff east of the tailings pile either flows into a borrow area east of the site and then down the escarpment onto the floodplain or it reaches Many Devils Wash, which discharges into the San Juan River approximately $0.5 \mathrm{mi}(0.8 \mathrm{~km})$ east of the cell.

Three unnamed arroyos that cut the escarpment above the floodplain can be seen in the aerial photograph (Figure 3.3) taken before site cleanup. These arroyos were filled during the surface restoration activities at the site. According to a 1977 letter (Hans, 1977), seeps were identified and sampled in these arroyos.

In 1990, two seeps were identified originating from the escarpment of Mancos Shale (Figure 3.10). One seep (425) is located on the escarpment about $15 \mathrm{ft}$ $(5 \mathrm{~m})$ above the floodplain near the northern corner of the disposal cell. This seep is about $30 \mathrm{ft}(9 \mathrm{~m})$ long and consists of a series of drips under an overhanging, indurated sand lens within the Mancos Shale. The flow rate from the seepage face was approximately $0.5 \mathrm{gpm}(2 \mathrm{~L} / \mathrm{min})$ in January 1991 (DOE, 1991). The second seep (426) is located southeast of where Bob Lee Wash enters the San Juan River floodplain. This seep is approximately $5 \mathrm{ft}(2 \mathrm{~m})$ above the floodplain and flowed at a rate of about $1 \mathrm{gpm}(4 \mathrm{~L} / \mathrm{min})$ in January 1991. 


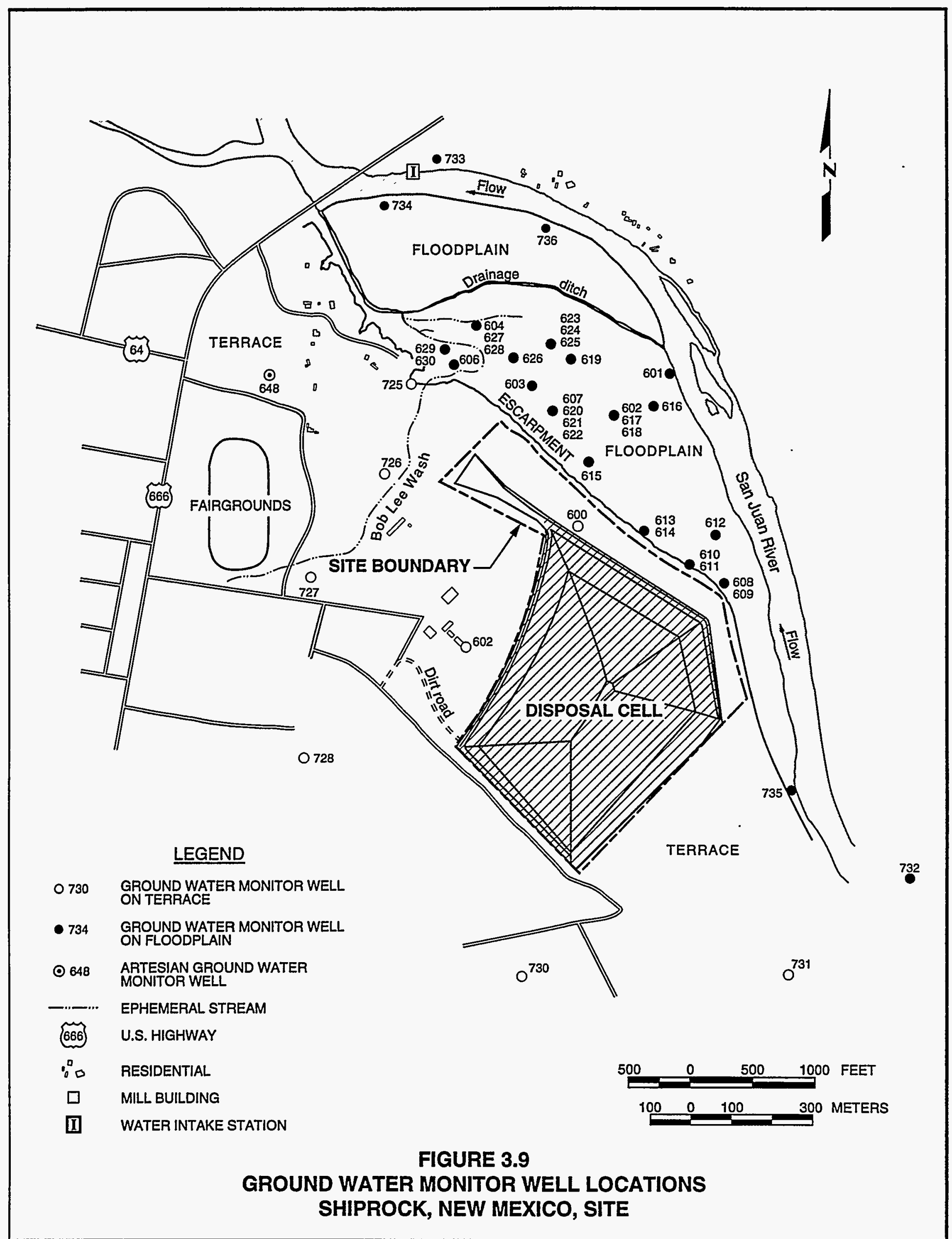




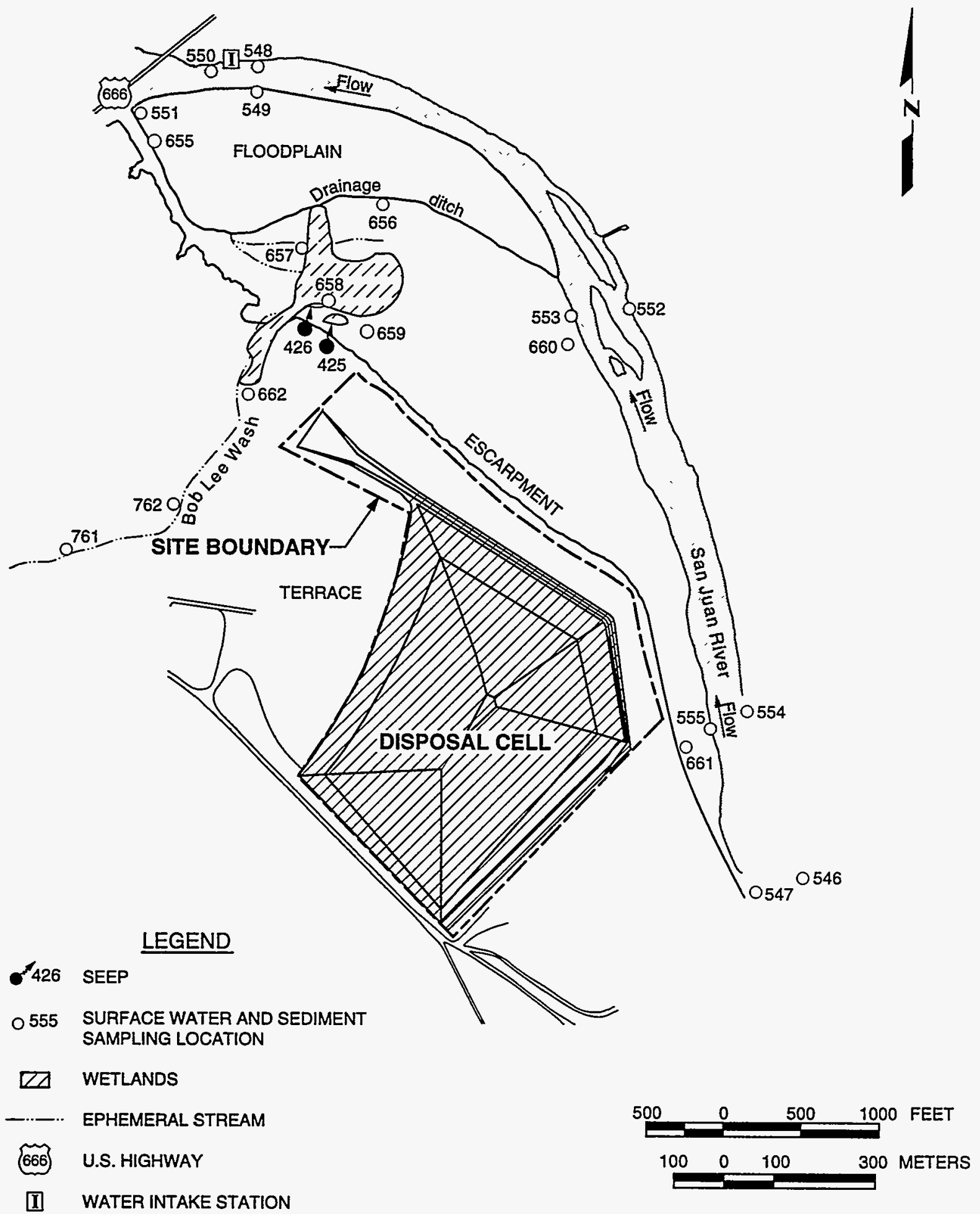

FIGURE 3.10

LOCATIONS OF FLOODPLAIN SURFACE WATER AND SEDIMENT SAMPLING STATIONS ADJACENT TO SHIPROCK TAILINGS SITE SHIPROCK, NEW MEXICO, SITE 


\subsubsection{Ground and surface water quality}

Water quality data were collected from 1984 to 1993 from monitor wells and surface locations at the Shiprock site. At present, 8 monitor wells are located on the terrace, 32 monitor wells are located on the floodplain, and 2 monitor wells are located on the opposite bank of the San Juan River. Eight surface water locations are currently monitored or have been sampled in the past. Water quality samples have also been collected from the artesian well (648) west of Bob Lee Wash, which is completed in the underlying regional aquifer in the Morrison Formation. Monitor wells and surface sampling locations are shown in Figure 3.9 and Figure 3.10, respectively. The existing UMTRA Project water quality data base for the Shiprock site consists of both filtered and unfiltered samples.

\section{Background water quality summary}

Background water quality is defined as the quality of water if uranium milling activities had not taken place and is discussed for both the terrace and floodplain aquifers.

Terrace system - Water quality data and well recovery data from wells in the vicinity of the processing site suggest that ground water in the terrace alluvium is derived mostly from the milling process and related activities. None of the ground water sampled from the monitor wells installed on the terrace can be considered representative of background conditions. Therefore, background ground water quality cannot be defined in the region immediately adjacent to the disposal cell.

Floodplain system - Analysis of geochemical data indicates that ground water in the floodplain aquifer below the terrace has been degraded by milling activities. Therefore, data from ground water in this area cannot be used to determine background conditions. Instead, background water quality is defined by monitor wells 732 and 733 completed in the alluvial system north and east of the San Juan River, respectively (Figure 3.9). Water quality data from two U.S. Geological Survey (USGS) wells (SJ3, approximately $9 \mathrm{mi}[14 \mathrm{~km}$ ] upstream and $\mathrm{G} 10$, approximately $8 \mathrm{mi}[13 \mathrm{~km}]$ downstream from the site) (Figure 3.11) were used to compare ground water quality in the shallow alluvial system above and below the Shiprock site.

Background ground water can be described as a sulfate-bicarbonate, calciumsodium type with slightly basic $\mathrm{pH}$ and TDS ranging from 800 to $5000 \mathrm{mg} / \mathrm{L}$. Although variable, background ground water from monitor wells $732,733,634$, and 635 has a similar chemical composition and falls into the same general chemical field. Variability in water chemistry can be explained by 1) distance of the well from the river (TDS decrease away from the river), 2) depth of the well (TDS appear to decrease with depth due to the diminishing effect of evaporation with depth) and 3) fluctuating chemistry of the San Juan River (discussed below). 


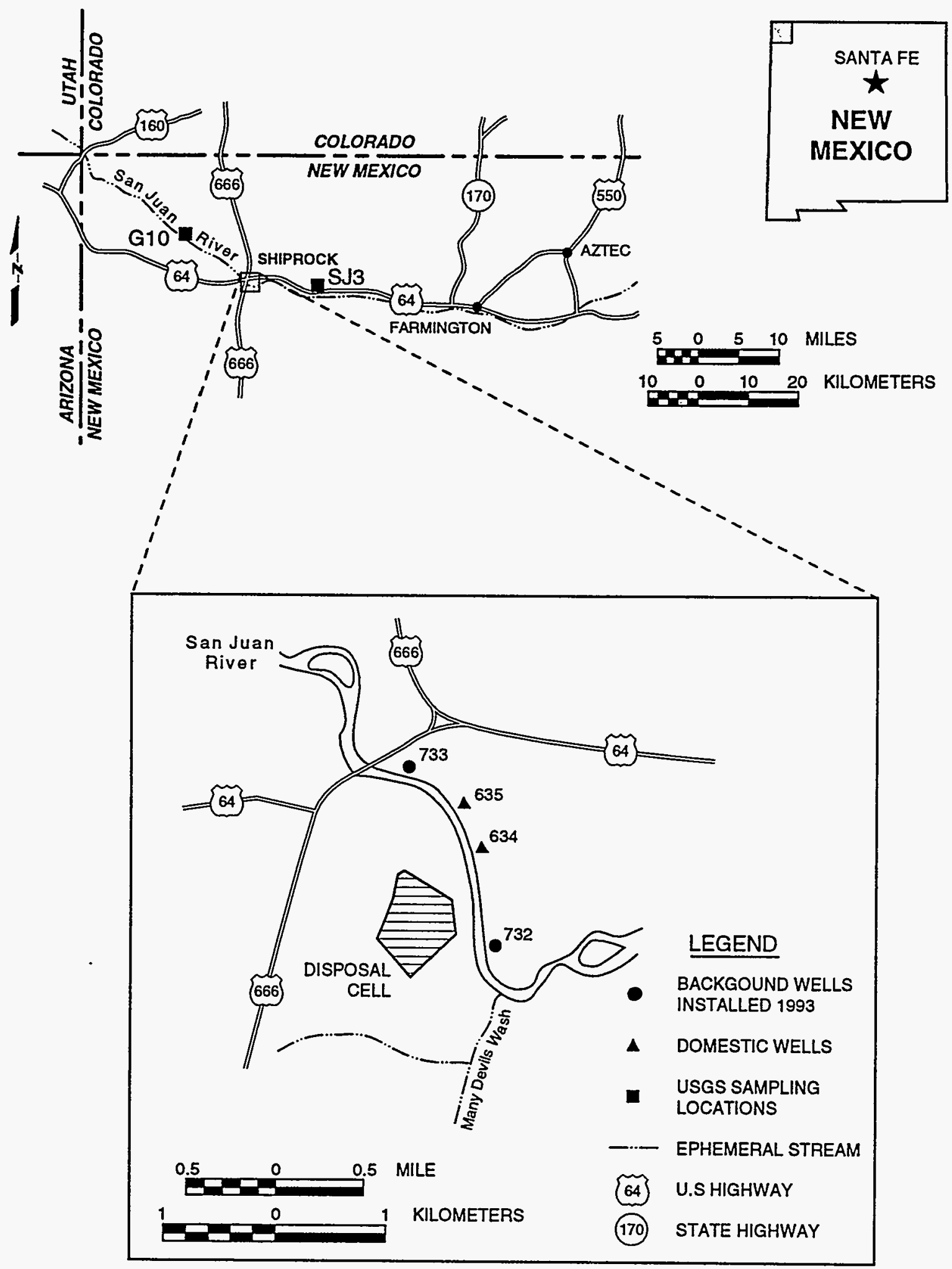

FIGURE 3.11

BACKGROUND WELLS USED FOR QUALITATIVE (SJ3, G10) AND QUANTITATIVE $(732,733,634,635)$ ANALYSIS OF GROUND WATER IN THE FLOODPLAIN AQUIFER SHIPROCK, NEW MEXICO, SITE 
The San Juan River influences ground water quality adjacent to the river channel. The solute load of the river varies depending on the volume of flow in the river, the amount of water each tributary contributes to flow (since the water quality is affected by the differing geologic formations each tributary flows through), and the evaporation rate. Because of these effects, ground water chemistry is not homogeneous in the floodplain adjacent to the river. Sulfate/chloride ratios in background wells in the alluvial aquifer range from 16 to 37 , illustrating the variability in solute concentrations in this system. A statistical summary of select water quality data for the four alluvial wells used to determine background is shown in Table 3.1 .

\section{Magnitude and extent of site-related contamination}

Uranium milling has impacted ground water in both the terrace and floodplain aquifers. Antimony, arsenic, cadmium, magnesium, manganese, nitrate, selenium, sodium, strontium, sulfate, and uranium were identified as COCs in the floodplain aquifer during the 1993 baseline risk assessment (DOE, 1994b). Because of their relative high concentrations, as compared to concentrations in the background ground water, uranium, nitrate, and sulfate, were chosen as indicator parameters and used to describe the magnitude and extent of the plume.

Ground water at the Shiprock site has not been screened for organic contaminants, including the EPA Appendix IV analytical suite. However, because an organic-based solvent extraction process was used to recover uranium from the pregnant solution (Section 3.1), some kerosene-derived organic compounds may be found in soils and ground water. Additional sampling and analyses will be required to evaluate the possibility of organic contamination.

\section{Terrace system}

The hydrogeologic conceptual model for the terrace supports the observation that water quality data from existing wells on the terrace are indicative of water from the milling activities. A statistical summary of COC water quality data for the terrace alluvium is presented in Table 3.2. Ground water monitor well locations are shown in Figure 3.9. Ground water from monitor wells 600 and 602, analyzed between 1988 and 1993, show high concentrations of uranium, nitrate, and sulfate. Ground water samples from monitor wells 725, 726, 727, 728 , and 731 , constructed in the spring of 1993 , were also high in nitrate, uranium, and sulfate. These monitor wells better define the extent of contamination to the east, south, and west of the disposal cell. The lateral extent of contamination has not been fully defined by the existing monitoring system.

Ground water flowing from the terrace aquifer to the floodplain aquifer contaminates ground water in the alluvial floodplain system, but the extent is unknown. This is apparent because water quality data from seep locations 425 


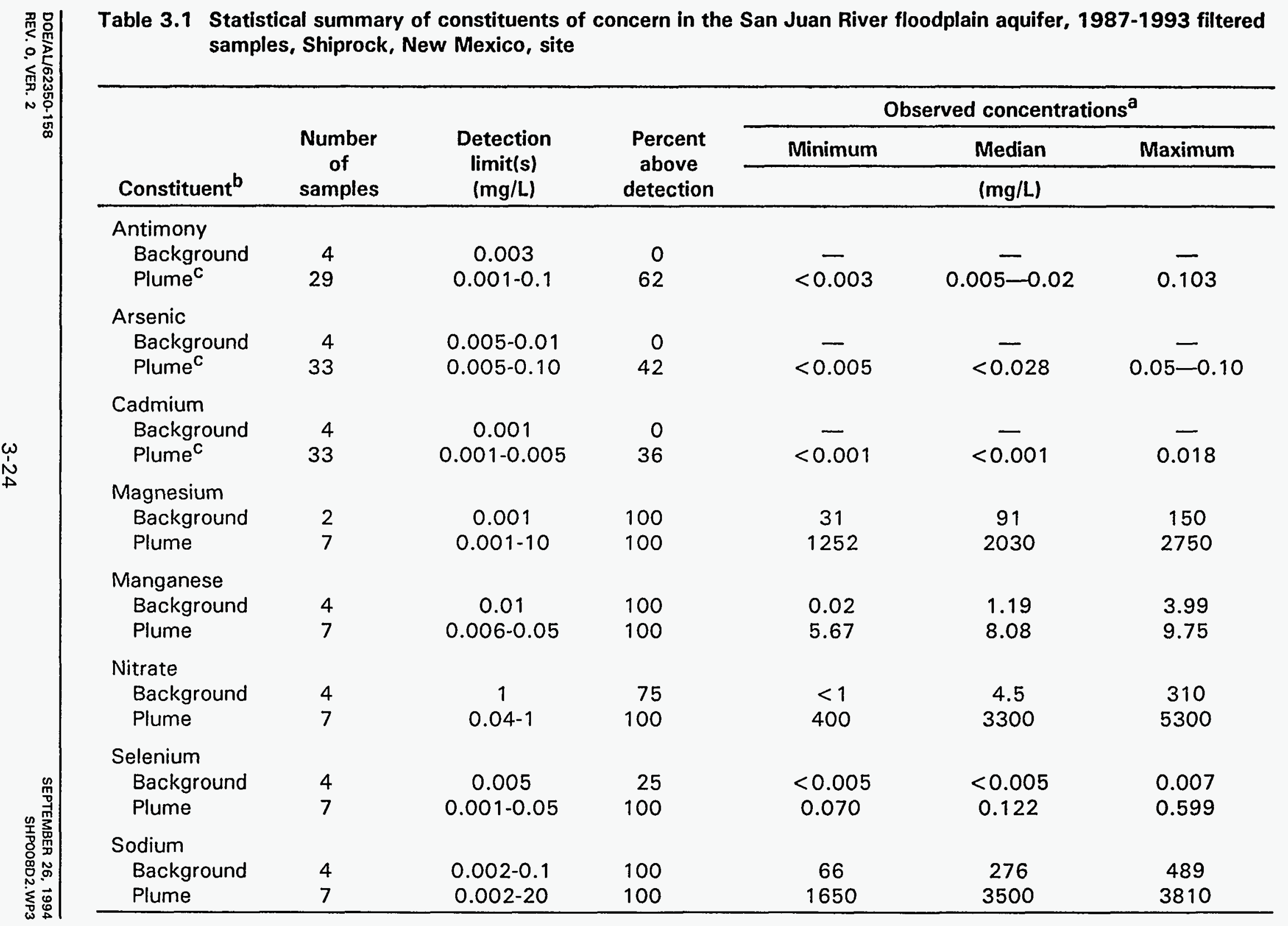




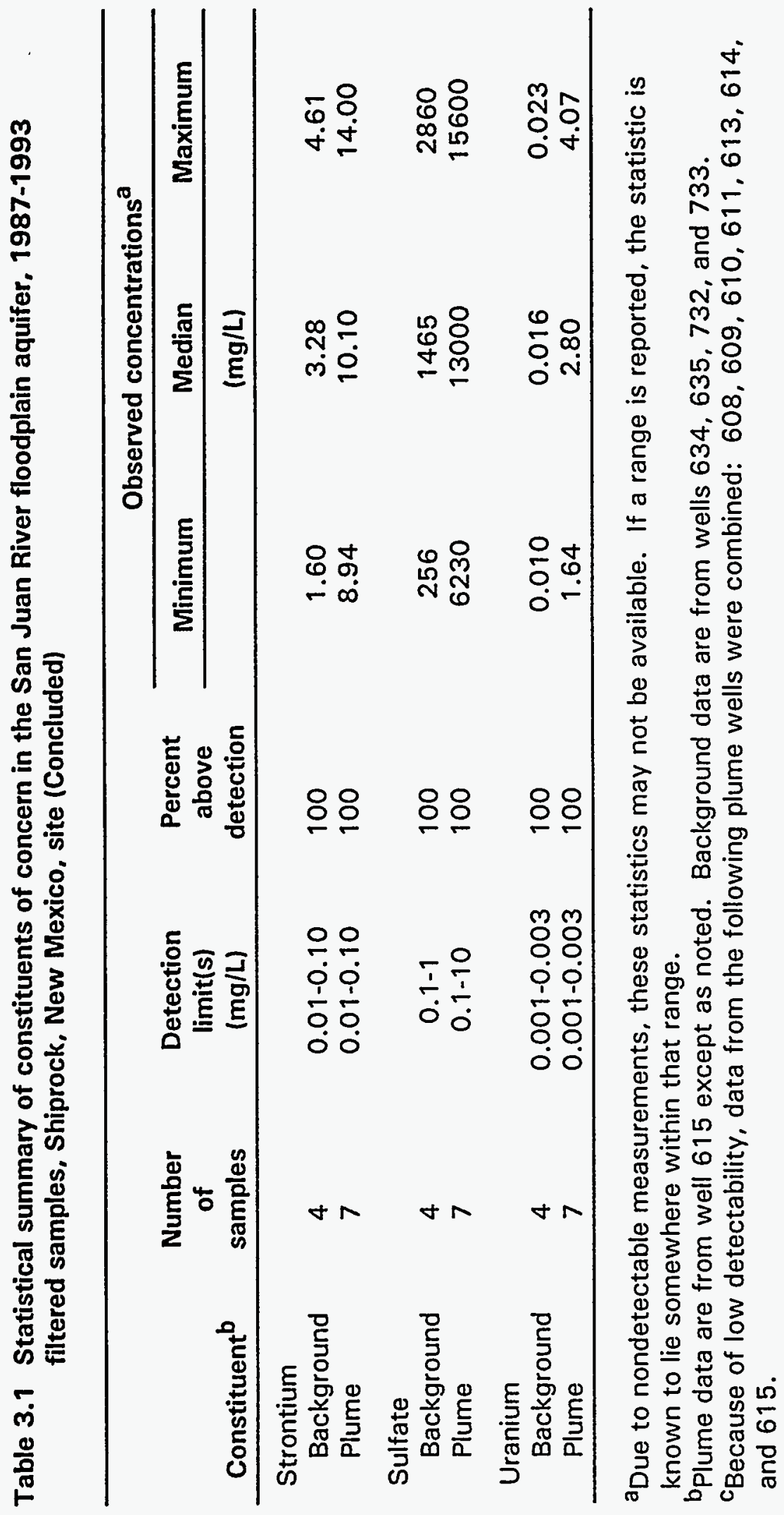




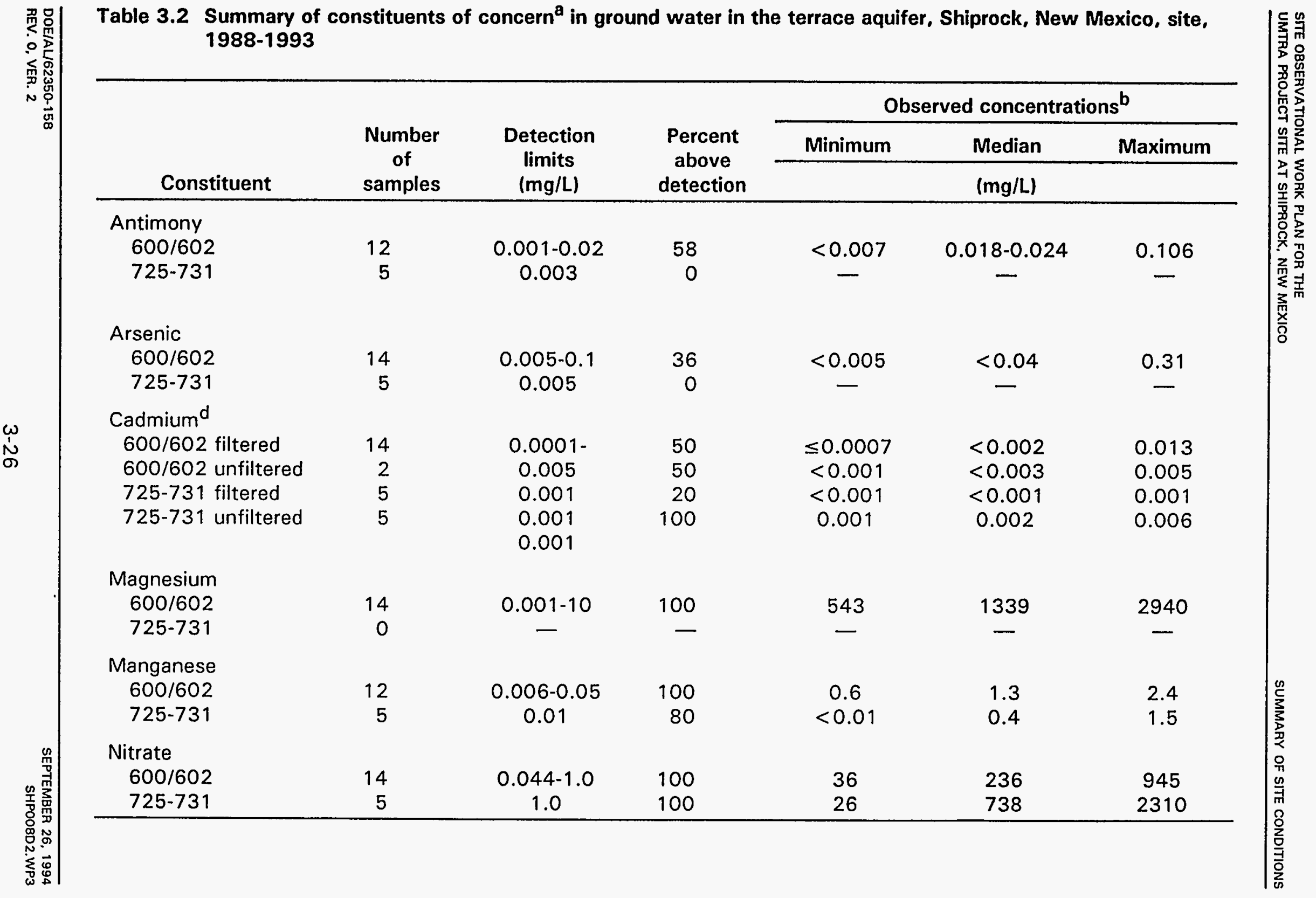


Table 3.2 Summary of constituents of concern ${ }^{\mathrm{a}}$ in ground water in the terrace aquifer, Shiprock, New Mexico, site, 1988-1993 (Concluded)

\begin{tabular}{|c|c|c|c|c|c|c|}
\hline \multirow[b]{3}{*}{ Constituent } & \multirow{3}{*}{$\begin{array}{c}\text { Number } \\
\text { of } \\
\text { samples }\end{array}$} & \multirow{3}{*}{$\begin{array}{c}\text { Detection } \\
\text { limits } \\
\text { (mg/L) }\end{array}$} & \multirow{3}{*}{$\begin{array}{c}\text { Percent } \\
\text { above } \\
\text { detection }\end{array}$} & \multicolumn{3}{|c|}{ Observed concentrations $^{b}$} \\
\hline & & & & Minimum & Median & Maximum \\
\hline & & & & & (mg/L) & \\
\hline \multicolumn{7}{|l|}{ Selenium } \\
\hline $600 / 602$ & 14 & $0.001-0.05$ & 57 & $<0.005$ & $0.04-0.06$ & 0.80 \\
\hline $725-731$ & 5 & 0.005 & 60 & $<0.01$ & 0.072 & 0.25 \\
\hline \multicolumn{7}{|l|}{ Sodium } \\
\hline $600 / 602$ & 14 & $0.002-20$ & 100 & 2120 & 3215 & 4090 \\
\hline $725-731$ & 5 & 0.1 & 100 & 534 & 1130 & 3030 \\
\hline \multicolumn{7}{|l|}{ Strontium } \\
\hline $600 / 602$ & 14 & $0.01-0.1$ & 100 & 6.2 & 9.2 & 15.6 \\
\hline $725-731$ & 5 & 0.01 & 100 & 4.9 & 7.4 & 14.7 \\
\hline \multicolumn{7}{|l|}{ Sulfate } \\
\hline $600 / 602$ & 16 & $0.1-10$ & 100 & 9200 & 13,900 & 18,100 \\
\hline $725-731$ & 5 & 1.0 & 100 & 3870 & 4,780 & 18,100 \\
\hline \multicolumn{7}{|l|}{ Uranium } \\
\hline $600 / 602$ & 14 & $0.001-0.01$ & 100 & 0.81 & 1.18 & 1.57 \\
\hline $725-731$ & 5 & 0.001 & 100 & 0.022 & 0.48 & 0.50 \\
\hline
\end{tabular}

${ }^{a}$ Data are from filtered samples unless otherwise noted.

b Due to nondetected measurements, these statistics may not be observable. If a range is given, the statistic is known to lie somewhere within the range.

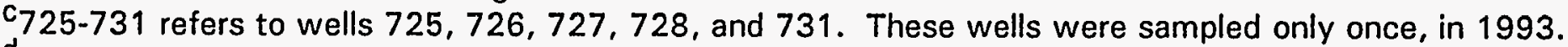

${ }^{\mathrm{d}}$ Concentrations from both filtered and unfiltered samples are presented for those constituents where filtering may be expected to remove a significant amount of the constituent from the water. However, when concentrations are low, natural variation and measurement error may be greater than the effects of filtering. 
and 426 (Figure 3.10), originating in the terrace alluvium, show elevated nitrate, uranium, and sulfate.

\section{Floodplain system}

The floodplain alluvium is characterized by elevated TDS and other constituents associated with uranium milling (e.g., sulfate, nitrate, and uranium). The horizontal distributions of sulfate, nitrate, and uranium are delineated in Figures $3.12,3.13$, and 3.14 , respectively. To characterize water quality in the floodplain and to determine constituents that are elevated above background levels, water quality data from wells showing the highest levels of contamination (monitor wells 608 through 613 and 615) between 1987 and 1993 were evaluated. Concentrations of COCs in the floodplain plume are summarized in Table 3.1. Ground water sampled from the floodplain wells has TDS values ranging from 700 to $64,200 \mathrm{mg} / \mathrm{L}$ and a $\mathrm{pH}$ ranging from 6.5 to 8.0. Uranium has been measured as high as $4.07 \mathrm{mg} / \mathrm{L}$ in monitor well 615 . The wide variability is attributed to differing flow paths of contaminated water from the terrace into the floodplain. These flow paths included surface transport of leachate and raffinate spills from the terrace onto the floodplain and from ponds constructed on the floodplain during mill operations. Contaminated ground water from the terrace is also transported through the various flow paths into the floodplain as identified in the conceptual model.

Monitor wells $608,610,614$, and 615 (Figures $3.12,3.13$, and 3.14 ) are in the high $\mathrm{COC}$ concentration portions of the plume along the base of the escarpment. Filtered water quality data collected between 1987 and 1993 indicate that monitor wells 608 and 615 have the highest concentrations of milling-related contaminants. Conversely, monitor well 612 appears to be somewhat diluted by flow from the San Juan River, especially during periods of high water flow. The remaining wells in the floodplain are located downgradient from the wells located in the plume; ground water in most of these wells is not as contaminated. Generally, ground water contamination in the floodplain shows a complex, heterogeneous distribution.

Time series analysis of chemical constituents show slight trends, either increasing or decreasing, of solute concentrations in ground water. In the most highly impacted area of the floodplain (the eastern portion), species such as nitrate and chloride appear to be increasing, sulfate and TDS are constant, and uranium shows a slight decrease. Observable concentrations of selenium and arsenic in ground water are sporadic and may in part be caused by analytical inconsistencies. An uneven distribution of COCs indicates that various plumes are present throughout the alluvial system. Furthermore, the distribution of contamination may be affected by preferential flow paths in the aquifer and by the location of ponds and episodic discharges onto different portions of the floodplain during the milling operations. 

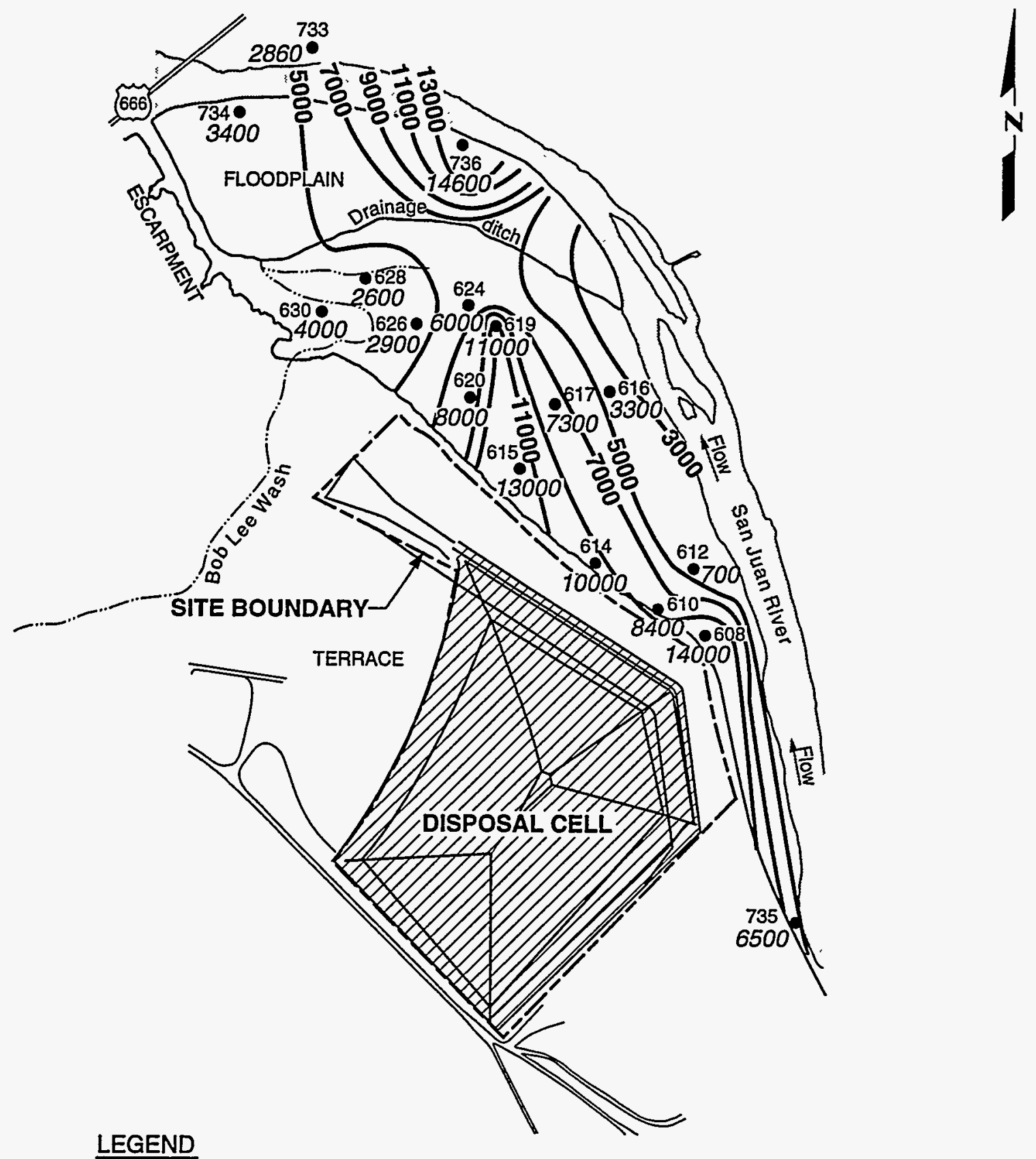

LEGEND

- 734 GROUND WATER MONITOR WELL

3400 SULFATE CONCENTRATION (mg/L)

5000 - SULFATE ISOPLETH

-..- EPHEMERAL STREAM

666 U.S. HIGHWAY

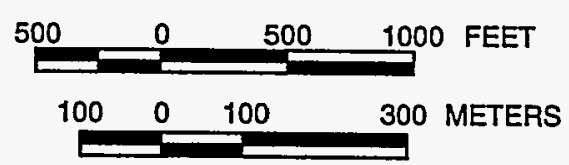

NOTE: WATER QUALITY DATA FROM SEPTEMBER 1992 EXCEPT MONITOR WELLS 734, 735, 736

FIGURE 3.12 (APRIL 1993); 612 (APRIL 1989).

\section{SULFATE CONCENTRATIONS IN FLOODPLAIN ALLUVIUM SHIPROCK, NEW MEXICO, SITE}




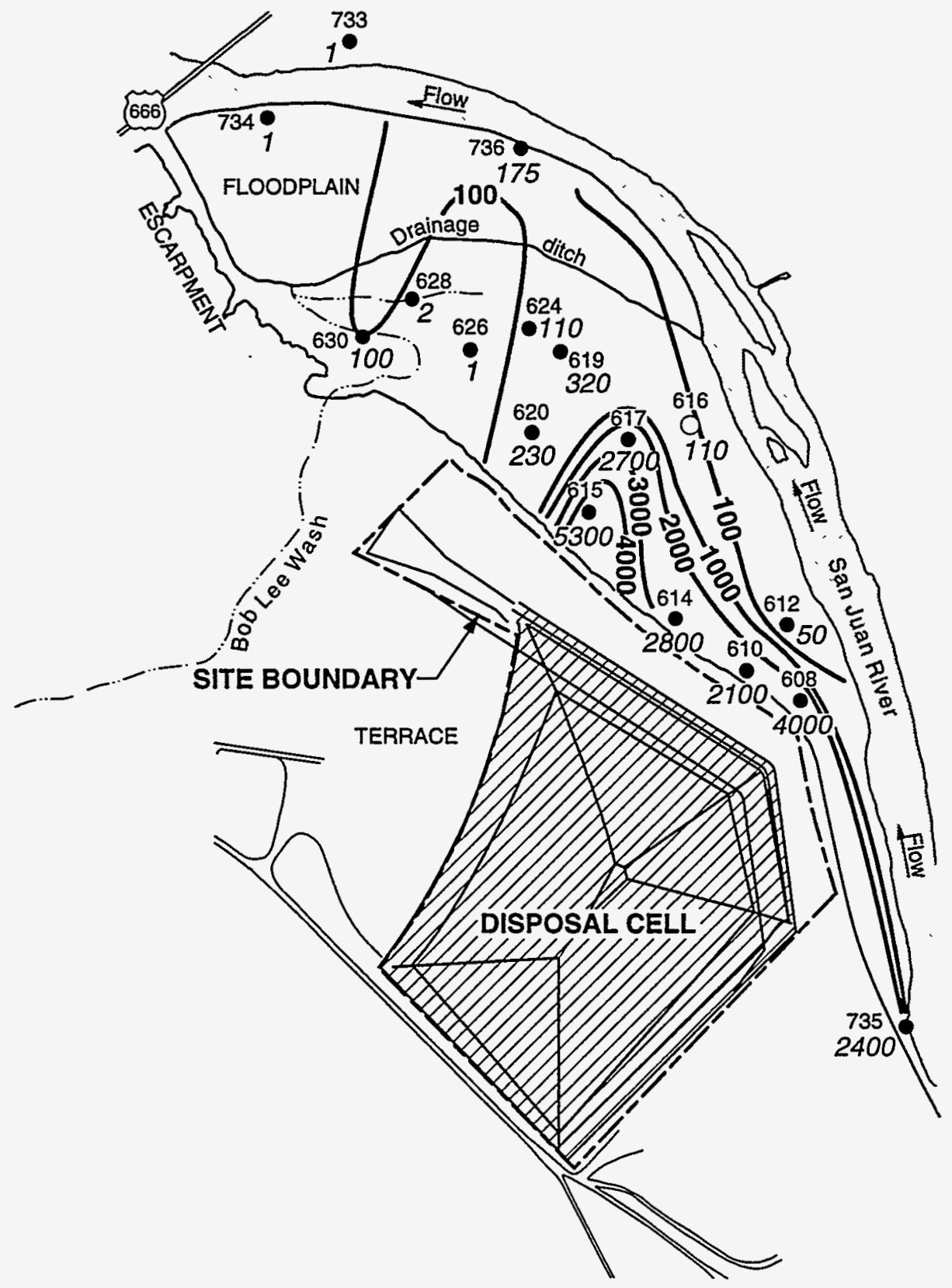

\section{LEGEND}

\section{GROUND WATER MONITOR WELL} NITRATE CONCENTRATION (mg/)

1000 - NITRATE ISOPLETH

-... EPHEMERAL STREAM

(666) U.S. HIGHWAY

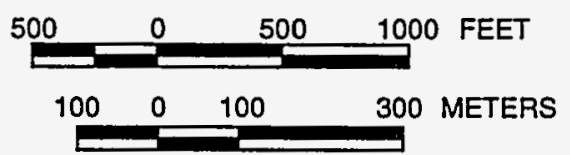

NOTE: WATER QUALITY DATA FROM SEPTEMBER 1992 EXCEPT MONITOR WELLS 734, 735, 736

(APRIL 1993), 612 (APRIL 1989), 603 (JUNE 1990).

FIGURE 3.13

NITRATE CONCENTRATIONS IN FLOODPLAIN ALLUVIUM SHIPROCK, NEW MEXICO, SITE 

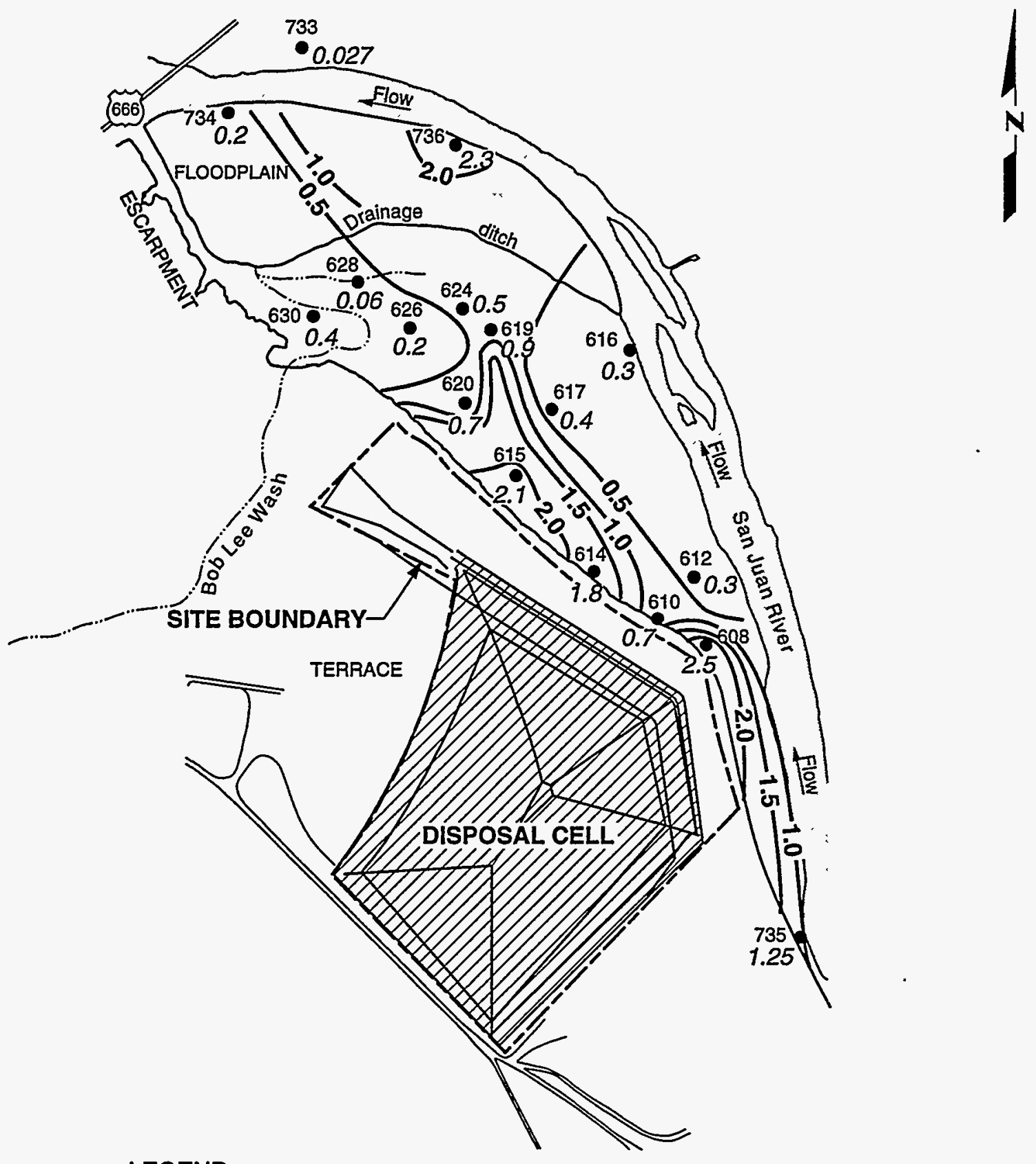

\section{LEGEND}

734 GROUND WATER MONITOR WELL

0.2 URANIUM CONCENTRATION (mgl.)

2.0 - URANIUM ISOPLETH

$500 \quad 0 \quad 500 \quad 1000$ FEET

$100 \quad 0 \quad 100$

300 METERS

- - EPHEMERAL STREAM

666 U.S. HIGHWAY

NOTE: WATER QUALITY DATA FROM SEPTEMBER 1992 EXCEPT MONITOR WELLS 734, 735, 736 (APRIL 1993), 612 (APRIL 1989).

\section{FIGURE 3.14 \\ URANIUM CONCENTRATIONS IN FLOODPLAIN ALLUVIUM SHIPROCK, NEW MEXICO, SITE}




\section{Surface Water}

Sampling locations for San Juan River surface water quality are shown in Figure 3.9. Analyses of one round of unfiltered water samples from seven San Juan River sampling locations $(546,552,554,548,549,550$, and 551), collected in February 1993, are summarized in Table 3.3. Downstream concentrations of arsenic, nitrate, sodium, and sulfate are statistically above background levels determined at the upstream locations. The remaining sampled COCs are at or below background values.

The impact of milling activities on the water quality of the San Juan River is difficult to determine because of the variable water chemistry and river flow (Goetz and Abeyta, 1987). However, mixing calculations presented in the Shiprock baseline risk assessment (DOE, 1994b) using water quality data and water flux from the San Juan River (at low flow) and contaminated ground water at the downstream edge of the floodplain (monitor well 736) show that concentrations of the COCs are within the range of ambient San Juan River water quality (i.e., uranium at $0.006 \mathrm{mg} / \mathrm{L}$, nitrate at $0.5 \mathrm{mg} / \mathrm{L}$, and sulfate at $222 \mathrm{mg} / \mathrm{L}$ ). The results of this calculation suggest that the impact of contaminated ground water from the floodplain on San Juan River water quality is negligible.

\subsubsection{Contaminant fate and transport}

The fate and mobility of contaminants in ground water beneath and downgradient from the former processing site are discussed in this section. Aside from hydrodynamic dispersion, geochemical sinks in the aquifer are responsible for the reduction of contaminant concentrations in ground water. Chemical reactions (oxidation/reduction, sorption onto the aquifer matrix, precipitation, coprecipitation with other mineral phases), microbial reactions, transport due to the advective flow of ground water, and radioactive decay will reduce the concentration of contaminants along the flowpath. Sorption onto the aquifer matrix and precipitation are the primary processes that reduce contaminant concentrations.

The type and concentrations of species and complexes in natural waters depend on the concentration, availability of various anions and cations, and $\mathrm{pH}$ and Eh conditions. Species and saturation indices of the contaminants of concern have been calculated using the geochemical code MINTEQA2 (Allison et al., 1991) and 1993 water quality data from the most contaminated monitor wells on the alluvial floodplain (monitor wells 608 through 613 and 615). The fate of specific COCs in and down the contaminant flow paths are addressed in the following subsections and are applicable for both the terrace and floodplain aquifers. 
Table 3.3 Statistical summary of the San Juan River water quality at the Shiprock, New Mexico, site, February 25, 1993

\begin{tabular}{|c|c|c|c|c|c|}
\hline \multirow[b]{3}{*}{ Constituent } & \multirow{3}{*}{$\begin{array}{c}\text { Number of } \\
\text { samples }\end{array}$} & \multirow{3}{*}{$\begin{array}{c}\text { Detection } \\
\text { limit }\end{array}$} & \multicolumn{3}{|c|}{ Observed concentrations } \\
\hline & & & Minimum & Median & Maximum \\
\hline & & & & $(\mathrm{mg} / \mathrm{L})^{a}$ & \\
\hline $\begin{array}{l}\text { Arsenic }^{b} \\
\text { Upstream }^{c} \\
\text { Downstream }^{d}\end{array}$ & $\begin{array}{l}3 \\
4\end{array}$ & $\begin{array}{l}0.005 \\
0.005\end{array}$ & $\begin{array}{l}0.007 \\
0.008\end{array}$ & $\begin{array}{l}0.007 \\
0.010\end{array}$ & $\begin{array}{l}0.008 \\
0.012\end{array}$ \\
\hline $\begin{array}{l}\text { Cadmiume } \\
\text { Upstream } \\
\text { Downstream }\end{array}$ & $\begin{array}{l}3 \\
4\end{array}$ & $\begin{array}{l}0.001 \\
0.001\end{array}$ & - & - & - \\
\hline $\begin{array}{l}\text { Calcium } \\
\text { Upstream } \\
\text { Downstream }\end{array}$ & $\begin{array}{l}3 \\
4\end{array}$ & $\begin{array}{l}0.5 \\
0.5\end{array}$ & $\begin{array}{l}73 \\
69\end{array}$ & $\begin{array}{l}73 \\
90\end{array}$ & $\begin{array}{l}77 \\
95\end{array}$ \\
\hline $\begin{array}{l}\text { Chromium } \\
\text { Upstream } \\
\text { Downstream }\end{array}$ & $\begin{array}{l}3 \\
4\end{array}$ & $\begin{array}{l}0.01 \\
0.01\end{array}$ & $\begin{array}{l}0.03 \\
0.03\end{array}$ & $\begin{array}{l}0.03 \\
0.05\end{array}$ & $\begin{array}{l}0.03 \\
0.07\end{array}$ \\
\hline $\begin{array}{l}\text { Iron } \\
\text { Upstream } \\
\text { Downstream }\end{array}$ & $\begin{array}{l}3 \\
4\end{array}$ & $\begin{array}{l}0.03 \\
0.03\end{array}$ & $\begin{array}{l}42 \\
40\end{array}$ & $\begin{array}{l}44 \\
54\end{array}$ & $\begin{array}{l}47 \\
69\end{array}$ \\
\hline $\begin{array}{l}\text { Lead } \\
\text { Upstream } \\
\text { Downstream }\end{array}$ & $\begin{array}{l}3 \\
4\end{array}$ & $\begin{array}{l}0.003 \\
0.003\end{array}$ & $\begin{array}{l}0.024 \\
0.024\end{array}$ & $\begin{array}{l}0.025 \\
0.030\end{array}$ & $\begin{array}{l}0.026 \\
0.032\end{array}$ \\
\hline $\begin{array}{l}\text { Manganese } \\
\text { Upstream } \\
\text { Downstream }\end{array}$ & $\begin{array}{l}3 \\
4\end{array}$ & $\begin{array}{l}0.01 \\
0.01\end{array}$ & $\begin{array}{l}1.03 \\
0.88\end{array}$ & $\begin{array}{l}1.12 \\
1.10\end{array}$ & $\begin{array}{l}1.23 \\
1.17\end{array}$ \\
\hline $\begin{array}{l}\text { Molybdenum } \\
\text { Upstream } \\
\text { Downstream }\end{array}$ & $\begin{array}{l}3 \\
4\end{array}$ & $\begin{array}{l}0.01 \\
0.01\end{array}$ & - & - & - \\
\hline $\begin{array}{l}\text { Nitrate }^{b} \\
\text { Upstream } \\
\text { Downstream }\end{array}$ & $\begin{array}{l}3 \\
4\end{array}$ & $\begin{array}{l}1.0 \\
1.0\end{array}$ & $\begin{array}{r}<1.0 \\
1.1\end{array}$ & $\begin{array}{r}<1.0 \\
1.5\end{array}$ & $\begin{array}{r}<1.0 \\
1.7\end{array}$ \\
\hline $\begin{array}{l}\text { Seleniume } \\
\text { Upstream } \\
\text { Downstream }\end{array}$ & $\begin{array}{l}3 \\
4\end{array}$ & $\begin{array}{l}0.05 \\
0.05\end{array}$ & - & - & - \\
\hline $\begin{array}{l}\text { Sodium }^{b} \\
\text { Upstream } \\
\text { Downstream }\end{array}$ & $\begin{array}{l}3 \\
4 \\
\end{array}$ & $\begin{array}{l}1.0 \\
1.0\end{array}$ & $\begin{array}{l}35 \\
36\end{array}$ & $\begin{array}{l}35 \\
56\end{array}$ & $\begin{array}{l}36 \\
58\end{array}$ \\
\hline
\end{tabular}


Table 3.3 Statistical summary of the San Juan River water quality at the Shiprock, New Mexico, site, February 25, 1993 (Concluded)

\begin{tabular}{|c|c|c|c|c|c|}
\hline \multirow[b]{3}{*}{ Constituent } & \multirow{3}{*}{$\begin{array}{c}\text { Number of } \\
\text { samples }\end{array}$} & \multirow{3}{*}{$\begin{array}{c}\text { Detection } \\
\text { limit }\end{array}$} & \multicolumn{3}{|c|}{ Observed concentrations } \\
\hline & & & Minimum & Median & Maximum \\
\hline & & & \multicolumn{3}{|c|}{$(\mathrm{mg} / \mathrm{L})^{\mathrm{a}}$} \\
\hline \multicolumn{6}{|l|}{ Sulfate ${ }^{b}$} \\
\hline Upstream & 3 & 1.0 & 116 & 118 & 121 \\
\hline Downstream & 4 & 1.0 & 121 & 190 & 205 \\
\hline \multicolumn{6}{|l|}{ Strontium } \\
\hline Upstream & 3 & 0.01 & 0.82 & 0.83 & 0.85 \\
\hline Downstream & 4 & 0.01 & 0.80 & 1.12 & 1.18 \\
\hline \multicolumn{6}{|l|}{ Uranium } \\
\hline Upstream & 3 & 0.001 & $<0.001$ & 0.001 & 0.002 \\
\hline Downstream & 4 & 0.001 & 0.001 & 0.001 & 0.001 \\
\hline \multicolumn{6}{|l|}{ Vanadium } \\
\hline Upstream & 3 & 0.01 & 0.09 & 0.09 & 0.09 \\
\hline Downstream & 4 & 0.01 & 0.08 & 0.11 & 0.14 \\
\hline \multicolumn{3}{|l|}{ Radionuclides } & \multicolumn{3}{|c|}{$\mathrm{pCi} / \mathrm{L}$} \\
\hline \multicolumn{6}{|l|}{ Lead-210 } \\
\hline Upstream & 3 & & 2.1 & 2.6 & 3.3 \\
\hline Downstream & 4 & & 1.0 & 1.8 & 2.6 \\
\hline \multicolumn{6}{|l|}{ Polonium-210 } \\
\hline Upstream & 3 & & 0.0 & 0.0 & 0.3 \\
\hline Downstream & 4 & & 0.0 & 0.3 & 1.1 \\
\hline \multicolumn{6}{|l|}{ Radium-226 } \\
\hline Upstream & 3 & & 1.3 & 2.5 & 2.9 \\
\hline Downstream & 4 & & 1.5 & 1.8 & 1.9 \\
\hline \multicolumn{6}{|l|}{ Thorium-230 } \\
\hline Upstream & 3 & & 0.1 & 0.2 & 0.3 \\
\hline Downstream & 4 & & 0.1 & 0.2 & 0.6 \\
\hline
\end{tabular}

anfiltered water samples.

b Statistically elevated above background at the 0.05 level of significance.

CUpstream locations: 546, 552, 554 (each location sampled one time).

dDownstream locations: 548, 549, 550, 551 (each location sampled one time).

Analyzed for, but not detected. 


\section{Antimony}

Low concentrations of antimony are present in ground water, probably in the $\mathrm{Sb}(\mathrm{III})$ and $\mathrm{Sb}(\mathrm{V})$ oxidation states and complexed as an oxyion or hydroxyl. Oxide and hydroxide solid phases are thermodynamically oversaturated in ground water where measurable quantities of antimony exist. Although not much is known about the kinetics of precipitation or sorption, antimony is not measurable in wells downgradient from monitor well 615. This suggests that either sorption onto aquifer materials, such as metal oxides or clays (Rai and Zachara, 1984), or precipitation is controlling the concentration of antimony in the ground water flow path.

\section{Arsenic}

Arsenic is present in ground water as an As(V) oxyanion. Arsenic is moderately mobile in an oxidizing aqueous environment as an arsenate species but generally, the mobility increases as the oxidation state of arsenic decreases (Rai and Zachara, 1984). Arsenite (As(III)) has a greater solubility with respect to solid mineral phases, and aqueous species generally sorb to the aquifer matrix less readily than $A s(V)$ species. Hydrodynamic dispersion and sorption onto aquifer materials (i.e., metal oxides and clay minerals [Rai and Zachara, 1984]) are responsible for low concentrations of arsenic in ground water downgradient from the contaminant plume.

\section{Cadmium}

Cadmium is present in the plume in low concentrations as a divalent cadmium ion and complexed with carbonate, sulfate, and nitrate. According to geochemical modeling, cadmium is undersaturated with respect to ground water, suggesting that hydrodynamic dispersion (dilution), sorption onto organic and inorganic aquifer materials (Rai and Zachara, 1984), and ion exchange are responsible for decreased concentrations in the flow path.

\section{Magnesium}

Magnesium is present in ground water as a magnesium ion and complexed with sulfate and carbonate. The mineral phase magnesite is saturated with respect to ground water in the region of the plume. Magnesium will also be diluted through hydrodynamic dispersion and cation exchange with other cations in clay minerals. These processes reduce the concentrations in ground water in the flow path.

\section{Manganese}

The mobility of manganese is primarily controlled by the redox state of the aquifer. Manganese is present in ground water in the $\mathrm{Mn}(\mathrm{II})$ valence state predominant as $\mathrm{Mn}^{2+}$ and complexed with sulfate and bicarbonate. Removal of manganese through sorption onto organic and inorganic aquifer materials (Rai 
and Zachara, 1984) and coprecipitation with iron phases may be occurring down the ground water flow path. Concentrations of manganese decrease downgradient from the plume, indicating attenuation is taking place in the flow path.

\section{Nitrate}

Nitrogen contamination is present predominantly as nitrate (N(V)) and ammonium ( $\mathrm{N}(\mathrm{II}-\mathrm{l})$ ) in contaminated ground water. The nitrate plume in the alluvial floodplain (Figure 3.13) is currently moving north towards the San Juan River. The predominant mechanism responsible for the attenuation of nitrate in ground water is most likely denitrifying reactions that occur under suboxic conditions ( $<1 \mathrm{mg} / \mathrm{L}$ dissolved oxygen [DO]), which exist in ground water on the terrace and alluvial floodplain. Furthermore, the absence of oxygen and elevated level of nitrate in ground water suggest that nitrate is controlling the redox condition of ground water in the plume. Nitrate concentrations in ground water decrease from approximately $5300 \mathrm{mg} / \mathrm{L}$ in monitor well 615 to $100 \mathrm{mg} / \mathrm{L}$ in monitor wells 624 (northwest of the plume) and 616 (southeast of the plume) (1993 water quality data). The decrease in concentration suggests that nitrate is probably biologically transformed into molecular nitrogen in the aquifer along the ground water flow path. This is probably the case because 1) very little nitrate sorbs onto the aquifer matrix due to the conservative nature of nitrate and 2) no nitrate solid mineral phases are thermodynamically saturated with respect to ground water in the region of the plume.

\section{Selenium}

Selenium is associated with uranium ore and is mobilized along with uranium during the acid leach portion of the milling process. Selenium as selenite, (Se(IV)), is the predominant species in the plume. Selenium concentrations decrease downgradient from the center of the plume, indicating that selenium is attenuated from ground water down the flow path. No selenium mineral phases are saturated with respect to ground water. This suggests that selenium is primarily removed from ground water through sorption onto the aquifer matrix due to the presence of ferric oxyhydroxides (Rai and Zachara, 1984) and diluted due to hydrodynamic dispersion.

\section{Sodium}

The addition of sodium chlorate as an oxidizing agent, dissolution of sodium minerals during the acid leach circuit, and cation exchange with calcium and magnesium in clays are responsible for the elevated concentration of sodium in contaminated ground water. Sodium is present in ground water predominantly as a cation, $\mathrm{Na}(\mathrm{l})$. The primary mechanism of sodium attenuation is most likely cation exchange with clay minerals, but sodium acts as a somewhat conservative cation if calcium or other divalent alkali earth elements are present in elevated concentrations within the system. Therefore, if divalent cations 
saturate clay exchange sites, sodium is expected to persist in ground water downgradient from the former mill site.

\section{Strontium}

Strontium is present in ground water primarily as the divalent strontium ion. Although no strontium mineral phases are saturated with respect to ground water, coprecipitation with gypsum and carbonate phases may remove some strontium from ground water. Along with hydrodynamic dispersion processes, cation exchange with clay minerals in the aquifer matrix will also reduce strontium concentrations.

\section{Sulfate}

Elevated concentrations of sulfate in ground water in the plume are due to the addition of $\mathrm{H}_{2} \mathrm{SO}_{4}$ during the milling process and the oxidation of sulfide minerals. Sulfate is present in ground water predominantly as a $\mathrm{SO}_{4}{ }^{2-}$ ion or is complexed with calcium, magnesium, or sodium. The mineral phase gypsum is saturated with respect to ground water in the alluvial and terrace systems and thus will most likely serve as a mechanism for the removal of sulfate from ground water. Ground water accessed by monitor wells directly downgradient from the most contaminated wells on the floodplain, monitor wells 615 and 608 (Figure 3.12), shows a decrease in sulfate concentrations. However, maximum concentrations of sulfate measured in ground water on the downstream edge of the floodplain at monitor well 736 approach $14,600 \mathrm{mg} / \mathrm{L}$, greater than what was measured in the center of the plume. This may be a hot spot of contamination and illustrates the heterogeneous distribution of contamination on the floodplain. As the plume migrates, hydrodynamic dispersion effects and precipitation of gypsum will be responsible for the decrease of sulfate concentrations along the ground water flow path. However, sulfate is expected to persist in the ground water for some time.

\section{$\underline{\text { Uranium }}$}

Uranium is present in ground water in the floodplain as a residual product of the milling process. Uranium is present in the plume predominantly as U(VI), uranyl tricarbonate, and dicarbonate complexes. These species are mobile under moderately oxidizing ground water at neutral $\mathrm{pH}$, conditions characteristic of the plume. Geochemical modeling indicates that no uranium mineral phases are saturated in the ground water. Therefore, sorption onto aquifer materials, i.e., iron oxyhydroxides (Kent et al., 1988; Hsi and Langmuir, 1985; Leckie et al., 1980) and organic materials (Nakashima, 1992), is most likely responsible for the removal of uranium from contaminated ground water down the flow path. 


\subsubsection{Risk evaluation}

This risk evaluation reflects findings presented in the draft Baseline Risk Assessment of Ground Water Contamination at the Uranium Mill Tailings Site near Shiprock, New Mexico (DOE, 1994b).

\section{Terrace system}

The hydrogeologic conceptual model of the terrace system has characterized the aquifer as a limited resource due to low yield properties of the aquifer.

Therefore, no exposure pathways are expected for humans, livestock, or wildlife for the terrace system. Ground water in the terrace aquifer cannot be fully evaluated until background ground water quality has been determined for this unit. However, the risk assessment has qualitatively evaluated the conditions in the terrace alluvium aquifer and has concluded that nitrate, sulfate, and uranium (Table 3.2) occur at concentration levels high enough to cause serious adverse health effects, even following short-term exposures should exposures occur. Because of the high concentrations of nitrate, sulfate, and uranium, the ground water is not suitable for use as drinking water or for livestock.

\section{Seeps along escarpment}

The seeps along the escarpment originate from contaminated ground water in the terrace aquifer. Because these seeps contribute contamination to water bodies identified on the floodplain, the seeps are addressed under the risk assessment to the floodplain system.

\section{Floodplain system}

At present, the San Juan River floodplain below the former uranium milling site is fenced, which restricts access to seeps and pools in the area. It is not expected that humans and domestic animals would be directly exposed to the seeps when alternate sources of good water are readily available in the immediate vicinity (such as Bob Lee Wash, artesian well water, or the San Juan River). Seep-contaminated surface water bodies existing on the floodplain could potentially form an incidental exposure pathway to humans, domestic animals, and wildlife. Levels of toxic constituents in seep water and sediments may result in adverse effects to aquatic and terrestrial organisms that reside in the area of the seeps should exposures occur.

The human exposure pathways that may occur on the floodplain include incidental ingestion of surface water and sediment, dermal contact with surface water, and consumption of contaminated meat or milk from livestock grazed and watered on the floodplain. Based on limited data, the risk assessment has determined that these exposures are not expected to immediately threaten human health. Additionally, adverse health effects would not be expected following ingestion of meat and milk from animals grazed and watered on the 
San Juan River floodplain. Additional data are required to completely evaluate the significance of these exposure pathways.

Potential exposure to livestock using the floodplain for forage and drinking water has also been evaluated. As a result of this evaluation, livestock could safely use the surface water bodies identified on the floodplain as their sole drinking water source, with the exception of the wet area below seep 425 . The health risks associated with incidental exposure of livestock or wildlife to the surface water in the pool below seep 425 are currently unknown. The nitrate levels observed in this water would be associated with methemoglobinemia in animals as a result of long-term exposure.

An analysis of surface water in the floodplain (excluding the seeps) and the San Juan River indicates that none of the constituents in these waters exceed Federal Water Quality Criteria for aquatic life. Based on this analysis, these bodies of water do not pose an ecological risk. However, additional sampling is required to verify this and determine if the constituents in the surface water have the potential to harm the terrestrial ecosystem. At the seeps, levels of nitrate and selenium could be toxic to aquatic organisms.

Terrestrial and aquatic organisms could be exposed to potential COCs in the floodplain alluvial aquifer via root uptake of contaminated water or construction of a pond using this water. An analysis of the potential for contaminants in the alluvial ground water that could be toxic to plants growing in the floodplains indicated that none of the constituents were present at levels high enough to result in phytotoxicity. However, concentrations of selenium and boron were close enough to phytotoxic levels to warrant additional study of these two contaminants. At the seeps, insufficient water quality criteria and sediment quality criteria were available to thoroughly evaluate the impacts of surface water and sediments to ecological receptors.

If a pond were filled with contaminated ground water from the floodplain aquifer, concentrations of antimony, chloride, manganese, nitrate, and selenium would exceed the Federal Water Quality Criteria, and such a pond would present a hazard to aquatic and possibly terrestrial organisms. In 1985, three waterfowl ponds were constructed in the floodplain. Concentrations of nitrate, sulfate, and uranium rose and in 1986 the ponds were filled in because they constituted a potential hazard to human health and the environment (Themelis, 1986).

The risk assessment has evaluated the COCs in the floodplain alluvium ground water. Several of these constituents (calcium, chloride, phosphate, potassium, and zinc) are essential nutrients, and the levels at which they are observed are within nutritional ranges even when added to expected dietary intake. Other contaminants (ammonium, boron, and nickel) exhibit low toxicity and are not expected to have toxic properties at measured concentrations. Arsenic, magnesium, manganese, nitrate, sodium, sulfate, and uranium remain as the contaminants of potential concern for the floodplain alluvium ground water. 
In general, limitations for the Shiprock ecological risk assessment include the following:

- Only a small amount of ecological data were collected during this screening.

- Little is known about site-specific intake rates for wildlife or amounts of contaminants taken up by plants. General literature values were used in many cases.

- Only limited ecotoxicological reference data are available.

- Considerable uncertainty is associated with the toxicity of mixtures of contaminants.

\subsection{EVALUATION OF INTERIM ACTION OPPORTUNITIES}

Because the contaminated zone in the San Juan River floodplain is currently fenced, no interim actions have been identified for the Shiprock site. Periodic maintenance of the fence should be conducted to continue restricting access of humans and livestock to the floodplain. 


\subsection{GROUND WATER COMPLIANCE STRATEGY SELECTION}

This section defines the ground water compliance strategy options, identifies the proposed ground water compliance strategies for the Shiprock site, explains the application of site-specific data to the ground water compliance selection framework, and analyzes possible deviations from the conceptual model, contingencies (alternatives to the compliance strategies), and decision rules (criteria) for application of contingencies.

\subsection{GROUND WATER COMPLIANCE STRATEGY}

Proposed ground water compliance decisions at the Shiprock site were made by using the compliance selection framework shown in Figures 4.1 and 4.2. This compliance selection framework was developed in the PEIS for the UMTRA Ground Water Project. The proposed ground water compliance strategies are selected by applying site-specific data to the framework. The three possible compliance strategies specified in the compliance selection framework are:

- No remediation - Application of the no remediation strategy would mean that compliance with the proposed standards would be met without altering the ground water or cleaning it up in any way. This could be applied at sites that have no contamination above MCLs or background levels, or at sites that have contamination above MCLs or background levels but qualify for supplemental standards or ACLs.

- Natural flushing - Natural flushing allows for the natural ground water movement and geochemical processes to decrease the contaminant concentrations to levels within regulatory limits within a given time period. This could be applied at sites where ground water compliance would be achieved with the application of natural flushing within 100 years, where effective monitoring and institutional controls could be maintained, and if the ground water is not currently and is not projected to be a drinking water source.

- Active ground water remediation - Active ground water remediation would require the application of engineered ground water remediation methods such as gradient manipulation, ground water extraction and treatment, and in situ ground water treatment to achieve compliance with the proposed standards.

\subsection{SITE-SPECIFIC GROUND WATER COMPLIANCE STRATEGIES}

Two separate ground water compliance strategies corresponding to each system for the Shiprock site (the terrace system and the floodplain system) are proposed by applying the site-specific information from Section 3.0 to the compliance selection framework. 


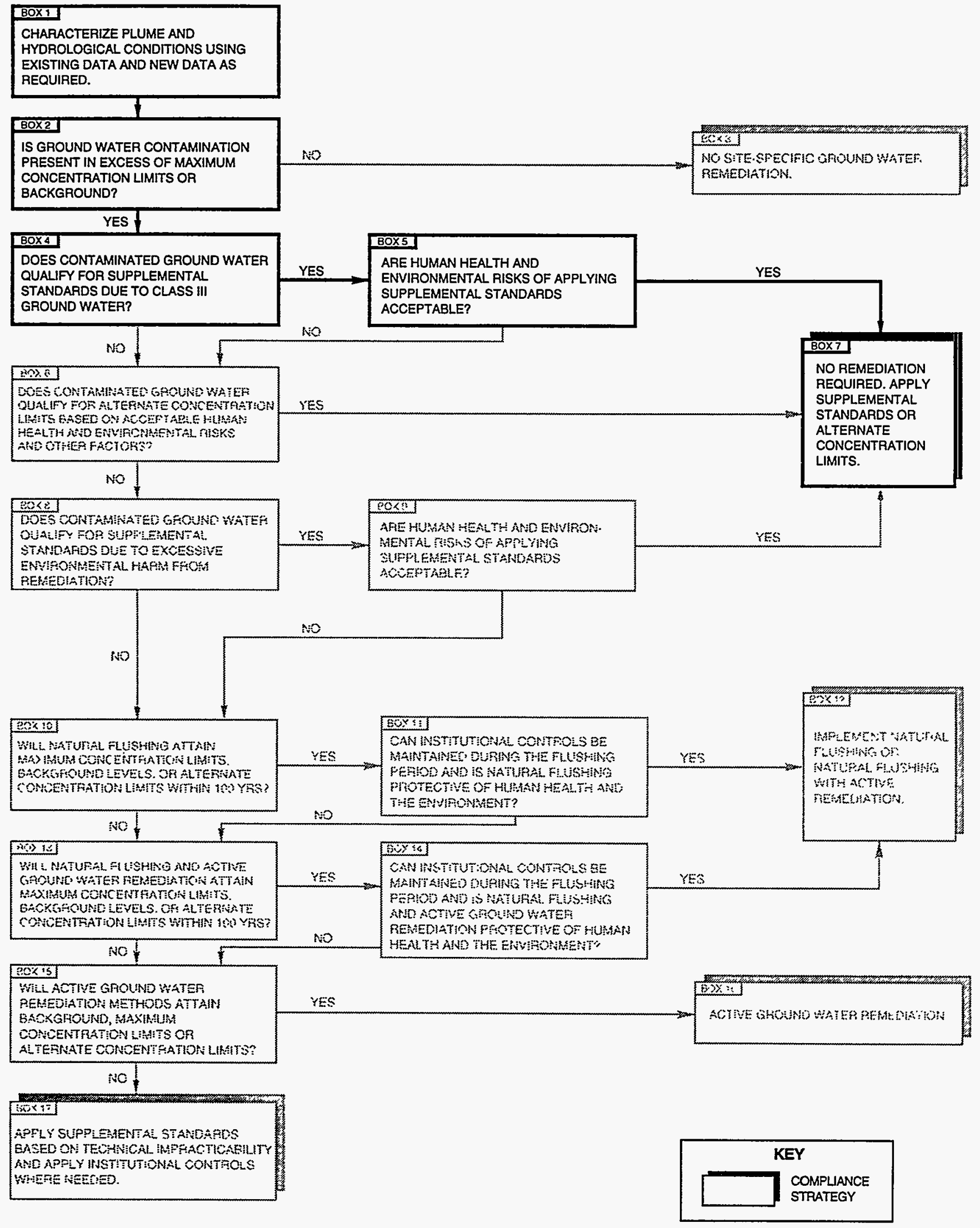

FIGURE 4.1

SHIPROCK TERRACE COMPLIANCE SELECTION FRAMEWORK SHIPROCK, NEW MEXICO, SITE 


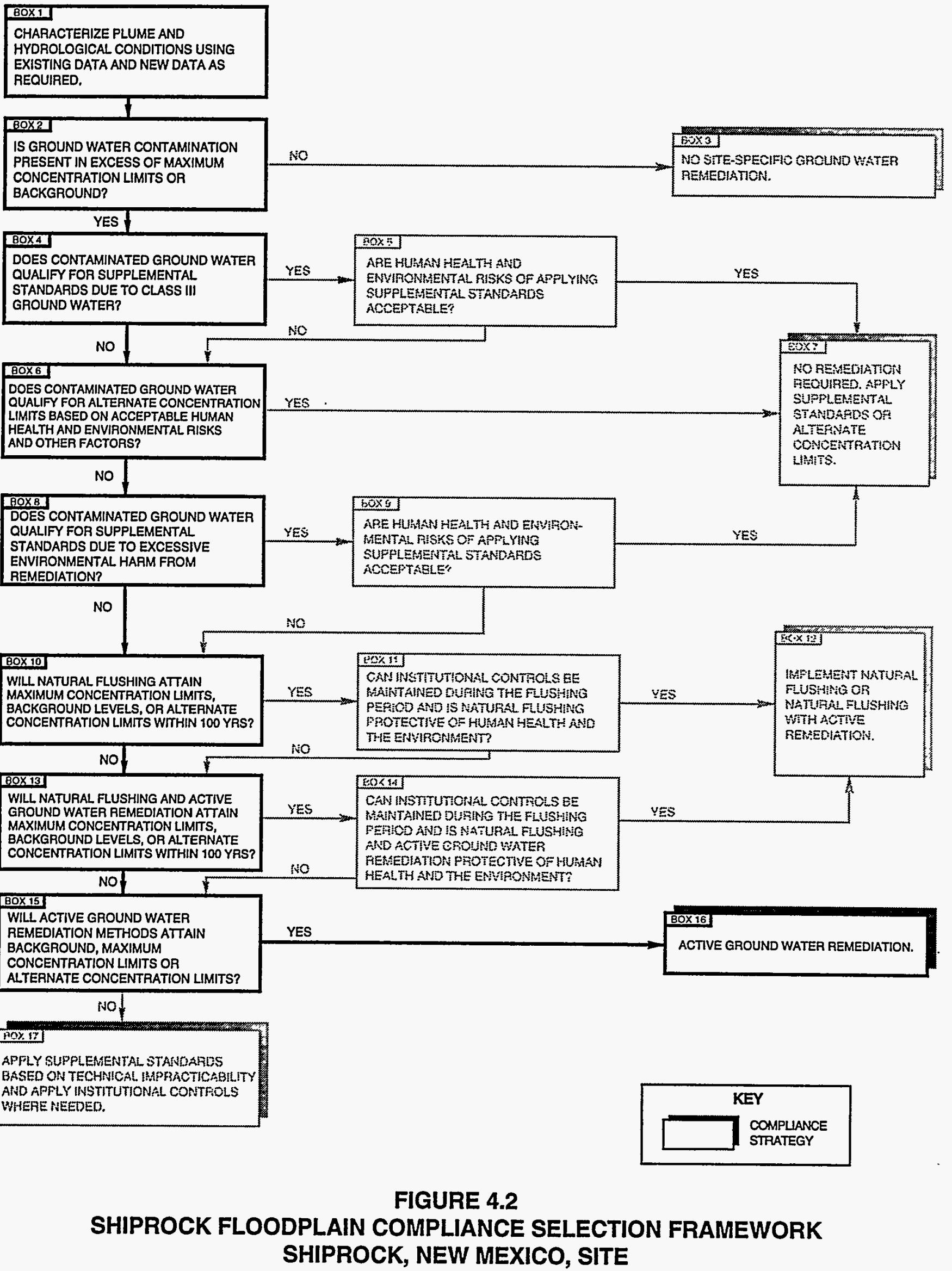


The proposed compliance strategy for the ground water in the terrace aquifer would be no remediation with application of supplemental standards based on limited-use ground water. The proposed compliance strategy for the contaminated water in the floodplain aquifer is active remediation for the identified COCs.

Analysis of ground water quality of the two contaminated ground water systems has revealed 19 constituents present in the ground water at the site that either exceed MCLs or background levels (box 2 in Figure 4.1). These constituents are ammonium, antimony, arsenic, boron, cadmium, calcium, chloride, magnesium, manganese, nickel, nitrate, phosphate, potassium, selenium, sodium, strontium, sulfate, uranium, and zinc. The application of each of these constituents to the compliance selection framework is shown in Figure 4.3. The presence of elevated levels of these constituents appears to be a direct result of past uranium milling operations.

The compliance selection framework was applied to the site-specific conditions present at the terrace and at the floodplain to determine the compliance strategies. The following sections describe the justification for selecting these proposed strategies.

\subsubsection{Terrace compliance strategy}

After analysis of site-specific conditions at the terrace, it was determined that compliance with the proposed standards could be achieved for the ground water by applying supplemental standards, since the ground water beneath the terrace should qualify as limited-use ground water based on low yield lbox 4 in Figure 4.1). The terrace aquifer is not expected to be capable of sustaining a well yield of 150 gallons $(570 \mathrm{~L})$ or more per day. It was determined that applying supplemental standards in this situation would protect human health and the environment, as there is no risk from exposure (box 5 in Figure 4.1) because the ground water is not a viable resource. Thus, the proposed compliance strategy for the terrace system is to conduct no site-specific remediation (box 7 in Figure 4.1) and apply for supplemental standards. The seeps at the escarpment are addressed in the floodplain compliance strategy (Section 4.2.2).

\subsubsection{Floodplain compliance strategy}

Analysis of the site-specific conditions at the floodplain indicates that the aquifer beneath the floodplain does not qualify as limited-use ground water (box 4 in Figure 4.2). Application of the conceptual model has shown that remediation of the floodplain aquifer for the 19 COCs detected at concentrations above background concentrations or MCLs will be more environmentally beneficial rather than harmful (box 8 in Figure 4.2).

Natural flushing is the next compliance strategy considered in the compliance framework. The time required for natural flushing depends on the location of 


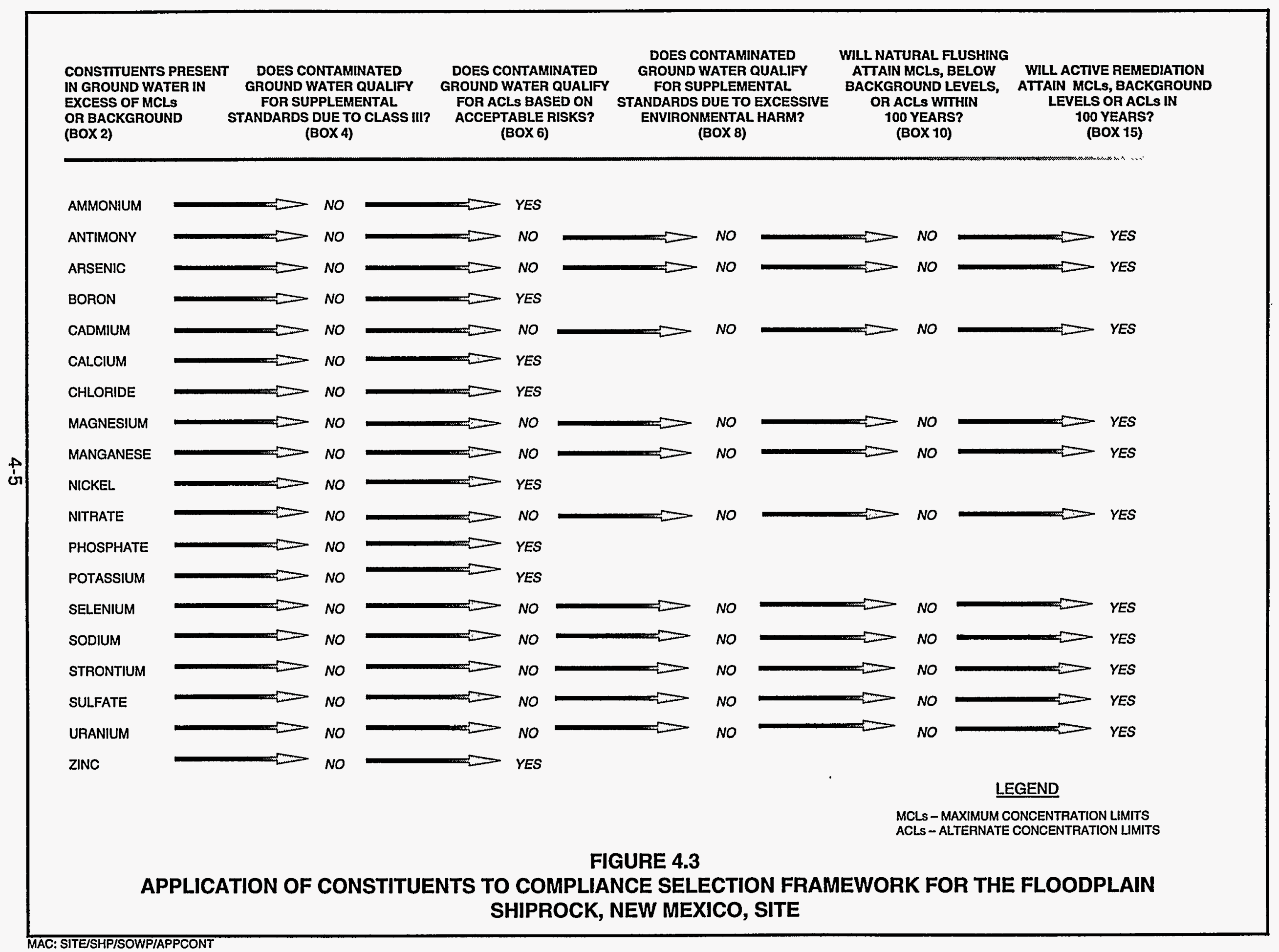


the ground water discharge point. Ground water is thought to be discharging from the floodplain into the San Juan River along the northwest edge of the floodplain, and contamination is present in the floodplain aquifer at the southeast edge (a distance of about 3000 feet [914 m]). Considering that hydraulic conductivities for the floodplain aquifer can range from about $5 \mathrm{ft} / \mathrm{day}$ $(0.001 \mathrm{~cm} / \mathrm{s})$ to $300 \mathrm{ft} / \mathrm{day}(0.1 \mathrm{~cm} / \mathrm{s})$ and that the hydraulic gradient is about 0.002 , it is estimated that one pore volume of water could take between 14 years to 800 years to flow the length of the aquifer. Using an intermediate hydraulic conductivity of $30 \mathrm{ft} / \mathrm{day}(0.01 \mathrm{~cm} / \mathrm{s})$ gives a period of about 140 years for one pore volume of water to pass along the length of the floodplain aquifer. If this value represents actual conditions in the floodplain aquifer, then natural flushing would not be a viable compliance strategy. Aquifer heterogeneity, adsorption, and other processes will not allow complete flushing of the aquifer in one pore volume, and many pore volumes may be required to achieve remediation (Fetter, 1993). Without active remediation of the seeps on the escarpment, there would be a continuing source of contaminants to the floodplain aquifer.

Since the no remediation compliance strategy is not applicable and natural flushing is not likely to be a viable compliance strategy, the proposed compliance strategy is active remediation. The recommended remediation method is to construct a permeable trench filled with material enriched with bacteria and nutrients to intercept contaminated ground water within the floodplain. This biological barrier would introduce bacteria into the aquifer to chemically convert the constituents into either a gas (e.g., nitrate to nitrogen) or into immobile precipitates. The material in the barrier would be replaced periodically with fresh material.

This remediation method is contingent on the results of bioremediation technology developed from a DOE-sponsored investigation by the University of New Mexico. This investigation has been proposed to evaluate the potential of in situ bioremediation at Shiprock. The investigation will study the proposed remedy of constructing a subsurface biological barrier permeable to ground water flow on the floodplain that will intercept the contaminants in the ground water before they can migrate off the site by discharge to the San Juan River. Laboratory work will be performed to establish the scientific basis for the technology. These investigations will include batch tests with samples of the floodplain alluvium, analysis of numbers and types of bacteria, and analysis of. types of precipitates. If the preliminary analyses are favorable, pilot field tests will be conducted before proceeding with the full barrier system.

The ground water surfacing from the seeps does not qualify for supplemental standards because there are risks to human health and the environment, especially livestock that might graze on the floodplain. As described in Section 3.3.1, seeps from the terrace are feeding ponds on the floodplain. Therefore, the seeps and ponds will be considered part of the floodplain system and will be governed by the proposed ground water compliance strategy of active remediation for the floodplain. The proposed remediation method would 
be to isolate the seeps to eliminate the point of exposure and address the seep waters with the active remediation of the floodplain.

\subsection{DEVIATIONS, CONTINGENCIES, AND DECISION RULES}

Possible deviations from the conceptual model and the proposed compliance strategies have been identified for the terrace and floodplain aquifers. Contingencies and decision rules have been identified for each possible deviation.

\subsubsection{Terrace aquifer}

\section{Deviations}

Deviations from the conceptual model may occur if testing shows that there is a natural aquifer on the terrace capable of sustaining a yield of more than $150 \mathrm{gal}$ (570 L) per day.

\section{Contingencies}

The contingency for this deviation is to revise the ground water compliance strategy to apply supplemental standards based on the technical impracticability of active remediation on the terrace. The technical impracticability is based on the conceptual model of the terrace, which identifies the upper Mancos Shale as being highly weathered and fractured. There is no known technology capable of extracting sufficient pore volumes of ground water from such a formation in order to remove the COCs to below background levels or MCLs. Nor is there is any known technology capable of in situ remediation in such a formation. Additional characterization would be necessary to demonstrate the appropriateness of this compliance strategy.

\section{Decision rules}

The decision rule for this contingency is based on aquifer tests conducted in background monitor wells that will be installed on the terrace away from the mound of contaminated process water. If tests show that the aquifer can sustain a yield of more than $150 \mathrm{gal}(570 \mathrm{~L})$ per day, additional characterization will be necessary to determine the appropriate compliance strategy.

\subsubsection{Floodplain aquifer}

\section{Deviations}

Deviations from the recommended remediation method for the floodplain aquifer may occur from:

- The inability of the biological barrier system to capture a sufficient amount of contaminated ground water before it discharges into the San Juan River. 
- The biological material in the barrier not removing a sufficient amount of contaminants from the ground water.

- The contaminants continuing to enter the floodplain aquifer either from the seeps on the escarpment or from flow through the fractured and weathered part of the Mancos Shale for such an extended period of time that the biological barrier system will not intercept all of the contaminated ground water within an economically reasonable time period.

- The floodplain can be classified as a wetland that may be harmed by a certain remediation methods, such as ground water extraction.

\section{Contingencies}

The contingencies for these possible deviations are:

- Extend the subsurface biological barrier so that all of the contaminated ground water is captured by the barrier.

- Modify the biological barrier material so that the contaminant removal efficiency of the barrier is higher.

- Switch to a broader bioremediation system that would augment natural biological processes in the alluvium. Augmentation may include adding soluble carbon source material to the aquifer to enhance anaerobic denitrification and sulfide precipitation of metals in the aquifer. Hot spot pumping of isolated portions of the aquifer may be necessary. Treatment of the water may be necessary if reintroduction of the water to the active bioremediation areas is not sufficient to remove the metals and nitrates. Water diverted from the artesian well (648) through constructed ditches along the floodplain close to the escarpment may be used to deliver the organic carbon source to the alluvial floodplain and increase the ground water gradient in the floodplain aquifer.

Seep water and fracture flow from the escarpment may be collected and directed through submerged trenches containing various natural to remove sulfates, metals, and nitrates before they reach the alluvial floodplain aquifer. Natural materials used could include various natural ion exchange zeolite soils and organic material. Removal of the trench material may be necessary as with a permeable biological barrier, if the metals buildup is excessive or if the ion-exchange capacity of the zeolite is exceeded.

- Enhance drainage from the alluvium of the terrace aquifer through the use of drainage trenches or horizontal boreholes constructed along the escarpment.

- Revise the proposed compliance strategy to no remediation based on ACLS for constituents whose concentrations are within acceptable human health and environmental risks (box 6 in Figure 4.2). These constituents are 
ammonium, calcium, chloride, phosphate, potassium, sodium, tin, and zinc. Of these constituents, calcium, chloride, phosphate, potassium, and zinc are essential nutrients and the levels at which they were detected are within nutritional ranges. Ammonium, boron, and nickel are found in concentrations low enough to be nontoxic (DOE, 1994b).

- If the floodplain can be classified as a wetland and the selected remediation method will likely affect the viability of the floodplain as a wetland, then supplemental standards will be applied to the floodplain because the remediation method will cause more environmental harm than benefit.

\section{Decision rules}

The decision rules for selecting among the contingencies in the event that the biological barrier cannot function as planned are presented below.

- If the ground water monitoring system on the floodplain shows that contaminated ground water is flowing around the barrier, allowing contaminated ground water to discharge into the San Juan River, the biological barrier would be modified to capture this water.

- The biological barrier material would be changed to a more efficient material if the levels of contaminants passing through the barrier are above regulatory limits.

- The augmented bioremediation and hot spot pump and treat system would be implemented if the costs of extending the barrier are prohibitive, if an assessment of the barrier material suggests that other materials are not more effective, or if natural flow of ground water through the barrier proves to be too slow for the floodplain aquifer to achieve compliance within an economically reasonable time period.

- Enhanced drainage from the terrace aquifer would be applied if the contaminants continue to enter the floodplain aquifer either from the seeps on the escarpment or from flow through the fractured and weathered part of the Mancos Shale for such an extended period of time that the biological barrier system will not intercept all of the contaminated ground water within an economically reasonable time period.

- Revision of the compliance strategy to no remediation for the eight constituents based on ACLs would be applied for any of the listed deviations from the proposed remediation method.

- If ground water extraction is selected as the remedial strategy, the floodplain will be evaluated to determine if it can be classified as a wetland. 


\subsection{DATA COLLECTION AND ASSESSMENT}

A variety of data collection activities are proposed to evaluate the effectiveness of the proposed compliance strategies to protect human health and the environment at the Shiprock site. The objectives of these data collection activities are presented in Section 5.1. The data needs that must be satisfied by the data collection activities and how they relate to the DCOs are presented in Section 5.2. Details of these activities and the DOOs are presented in Section 5.3.

\subsection{DATA COLLECTION OBJECTIVES}

The objectives of the data collection activities for the Shiprock site are to:

- Define the horizontal and vertical extent of contamination in ground water at the site.

- Characterize aquifer properties for the terrace and floodplain systems.

- Define biological and geochemical processes in the terrace and floodplain aquifers.

The horizontal and vertical extent of contamination in ground water needs to be defined to determine if levels of contaminants in ground water represent a risk to human health and the environment and to verify that the remediation method for the floodplain will perform as designed.

Aquifer properties need to be thoroughly characterized to determine if the terrace aquifer can be considered as a limited-use aquifer (yields less than $150 \mathrm{gpm})$, to help in the design of a remediation method for the floodplain, and to determine the degree of hydraulic interconnection between the terrace aquifer, the floodplain aquifer, and the San Juan River.

The biological and geochemical processes in the aquifer need to be defined to determine the amount of aquifer remediation taking place by natural processes, and to help in the design of an active remediation method for the floodplain, or the alternatives identified as contingencies.

\subsection{STATEMENT OF DATA NEEDS}

The existing site information indicated data needs that must be evaluated to more accurately define and support the proposed ground water compliance strategies and evaluate the feasibility of potential ground water remediation methods. 
The data needs for defining the horizontal and vertical extent of contamination in ground water are:

- Determining the concentration of COCs in ground water at the site.

- Measuring the specific conductance of ground water in the floodplain aquifer.

- Determining the structure of the top of the Mancos Shale for the terrace and the floodplain.

- Determining directions of ground water flow in the terrace and floodplain aquifers.

The data needs for characterizing aquifer properties are:

- Measuring the hydraulic properties of the lithologic units.

- Determining the ground water flow relationships between the terrace, floodplain, and San Juan River.

- Determining the sustainable yield of ground water from the terrace aquifer.

- Measuring the amount of water flowing from the seeps on the escarpment.

- Estimating the amount of water recharging the floodplain aquifer from the artesian well.

- Determining ground water flow velocities at the site.

The data needs for defining biological and geochemical processes in the aquifer are:

- Determining the rate of biological and geochemical properties affecting breakdown or attenuation of COCs in ground water.

- Calculating site-specific retardation factors and distribution coefficients for the COCs.

\subsection{DATA COLLECTION ACTIVITIES AND QUALITY OBJECTIVES}

Data collection activities have been identified that will ensure that the data collected will be sufficient to satisfy the objectives outlined above. DOOs are quantitative and qualitative statements made to ensure that data of known and appropriate quality are obtained during an investigation. To ensure that the data gathered during investigation activities are adequate to support stakeholder decisions, a clear definition of the objectives and the method by which decisions 
will be made will be established. These determinations are facilitated by the development of DQOs.

The data to be gathered from each proposed data collection activity and the quality objectives are discussed in the following sections.

\subsubsection{Surface geophysical surveys}

An electromagnetic (EM) survey will be conducted to establish bounds on the contaminant plume on the floodplain and, if feasible, on the terrace. Data from this survey will be used to assist in determining locations for new monitor wells and to establish the target area to be remediated.

Depths to the top of the Mancos Shale may be determined for the terrace with transient electromagnetic (TEM) methods; however, the expected depths to the Mancos Shale are at the low end of the optimal range for TEM methods. Modeling of the terrace geology will be conducted prior to the start of any geophysical field work. If the modeling shows that TEM methods are not appropriate for the site, other methods, such as seismic refraction or resistivity soundings, will be used.

Depths to the top of the Mancos Shale will be determined for the floodplain with either seismic refraction or resistivity soundings.

\section{Surface electromagnetic ground conductivity survey}

Surface EM ground conductivity surveys will be performed on the terrace and floodplain using EM34 instrumentation. Because of the more complex geology of the terrace, the EM34 method may not be appropriate; however, test soundings will be conducted on the terrace to determine the effectiveness of the instrument in this area. The grid for the EM34 survey will be determined in the field to take into consideration influences of natural conditions and to coordinate with monitor well locations to take advantage of correlation of data collected during the borehole fluid specific conductance survey.

The EM34 survey lines will be run parallel to the topography for optimum results. The location and configuration of the water table will also need to be considered in conducting the survey. Results of the EM34 survey will be used to determine the lateral extent of ground water contamination based on conductivity differences in the ground water.

\section{Surface transient electromagnetic soundings survey}

Based on information from initial geophysical surveys and modeling, areas of interest will be selected for geophysical investigation using surface TEM methods. EM47 instrumentation will be used to delineate the vertical extent of contamination in ground water and the top of the Mancos Shale. 
Locations for the EM47 surveys will be selected within and near the edges of the area of contaminated ground water to determine the vertical extent of siterelated contamination. These locations will be determined in the field, based on results of the other geophysical surveys. Measurements will be made at selected locations, and the depth of investigation will be determined by the size of the surface transmitter loop.

Interpretation of TEM sounding data will provide the depth, thickness, and conductivity of subsurface layers with different electrical conductivities. Soundings made along a straight-line traverse will provide a cross-sectional view of the area of ground water contamination.

\section{Data quality objectives for surface electromagnetic survevs}

The proposed areal coverage of the geophysical surveys is shown in Figure 5.1. The geophysical surveys will be limited to a depth of approximately $50 \mathrm{ft}$ $(15 \mathrm{~m})$. Geophysical data will be generated, verified, and documented in compliance with the UMTRA Project Quality Assurance Implementation Plan (QAIP) (DOE, 1994c). Geophysical data will be collected in accordance with the instrument manufacturer's specifications and standard field operating procedures. Results of the geophysical investigations will be evaluated using industry-approved methods and standard operating procedures (SOP).

Adherence to these practices will ensure that the data collected will be of sufficient quality to support the DCOs outlined above. These procedures will locate the lateral edge of the contaminant zone in ground water to within approximately $100 \mathrm{ft}(30 \mathrm{~m})$ and the vertical extent to within approximately $5 \mathrm{ft}$ $(1.5 \mathrm{~m})$.

The surface EM survey will be done with a Geonics EM34 tool (or equivalent). The EM34 can be set to focus on various depths depending on orientation and spacing of the coils. For the floodplain survey, the instrument would be set up to investigate no more than $20 \mathrm{ft}(6 \mathrm{~m})$ in depth to minimize the influence of variations in the elevation of the Mancos Shale. Horizontal resolution of measurements with this instrument should be within approximately $100 \mathrm{ft}$ $(30 \mathrm{~m})$, depending on physical conditions beneath the site. This method is sensitive to clay layers, which normally have an elevated electrical conductivity. Data from the EM34 survey will be used to provide information on the conductivity of clay layers relative to the conductivity of zones of contaminated ground water. If EM34 instrumentation is used on the terrace, it will measure the differences between the conductivity of the Mancos Shale and the overlying alluvium. Variables in the hydrogeologic system must be considered during data interpretation to verify the assumption that the contrast in conductivity in ground water is the dominant influence on the data.

The surface TEM soundings method (Geonics EM47 or equivalent) provides a means of determining the vertical changes in electrical conductivity correlating with differences in soil and rock layers and variations in the conductivity of fluids filling the pore spaces. Vertical resolution of measurements using EM47 


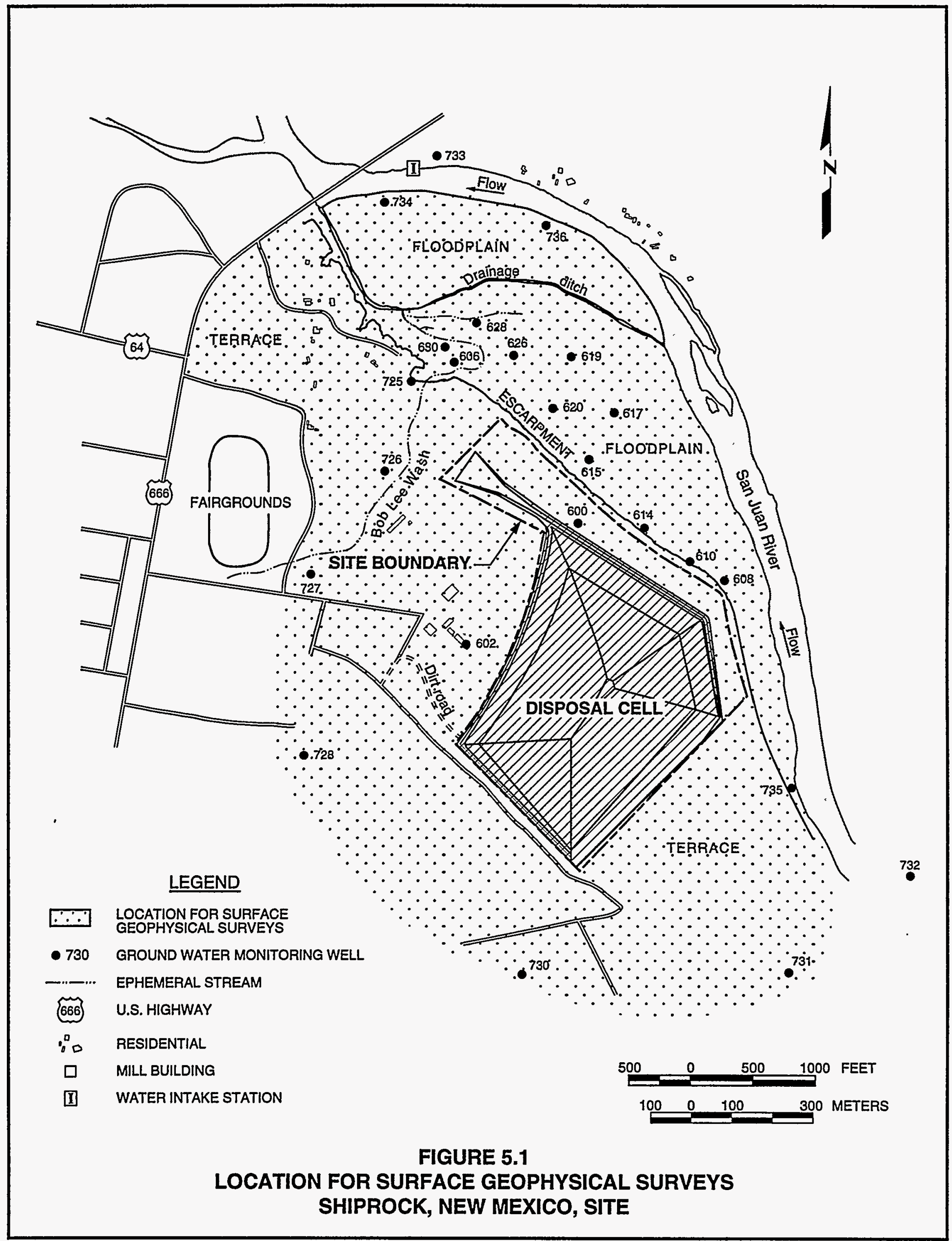


equipment should be within 5 to $10 \mathrm{ft}(1.5$ to $3 \mathrm{~m})$ of a contact between contrasting conductivities. Such soundings are optimal in the depth range from about 30 to $300 \mathrm{ft}(10$ to $100 \mathrm{~m})$.

\subsubsection{Borehole fluid conductivity surveys}

This activity will consist of taking in situ conductivity measurements of water in all accessible monitor wells to investigate the possibility of mill process fluids of greater densities than natural ground water remaining in low spots within the floodplain aquifer.

\section{Data quality objectives for borehole fluid conductivity survey}

The borehole fluid conductivity survey will be conducted using a YSI Model $6000 i$ multiparameter water quality monitor (or equivalent). Readings will be taken in each well every $0.5 \mathrm{ft}(0.15 \mathrm{~m})$ over the screen interval. Readings will be taken for specific conductivity, $\mathrm{DO}$, reduction-oxidation potential, $\mathrm{pH}$, and temperature.

\subsubsection{Core analysis}

Laboratory analysis of new and archived core samples is proposed to determine hydraulic conductivity, porosity, bulk density, specific yield, and grain size distribution of the lithologic units that can be cored. These analyses will provide more detailed small-scale information on aquifer characteristics than the pumping test results. Grain size analyses from the core samples are needed to determine the most efficient filter pack and screen slot size for new wells.

\section{Data quality objectives for core analysis}

Samples from the cores will be analyzed by a geotechnical engineering laboratory. Application of UMTRA Project SOP 15.2.2 (JEG, n.d.), "Laboratory Testing of Borehole Samples of Rock and Soil," will ensure that adequate procedures are followed.

\subsubsection{Monitor well installation}

The preliminary EM survey will provide a semiquantitative estimate of plume configuration. However, direct sampling will be necessary to confirm the actual constituent concentrations in ground water. The installation of additional monitor wells is contingent upon the results of the preliminary EM survey and the core analysis to help select gravel pack and screen size.

It is proposed that up to twelve 4-inch $(10-\mathrm{cm})$ diameter monitor wells be installed onsite. The monitor wells will be drilled and installed to provide access for water quality sampling for further plume definition, pumping tests for aquifer characterization, and water level measurements for defining ground water flow 
directions. The wells will be drilled and completed in accordance with UMTRA Project SOPs (JEG, n.d.).

Four monitor wells are planned to be installed in the terrace. Two of these monitor wells will be drilled to provide background ground water quality data and to characterize aquifer properties. The other two monitor wells will be drilled near the escarpment to measure aquifer properties, water levels, and water quality in the fractured and weathered Mancos Shale.

Eight monitor wells will be installed on the floodplain. The monitor well locations and depths may change based on the results and interpretations obtained from the surface geophysical and fluid conductivity surveys. One of the floodplain monitor wells will be screened within the fine-grained alluvium. At least three of the monitor wells will be screened within the coarse-grained alluvium, and at least three monitor wells will be screened in the top of the Mancos Shale to measure aquifer properties, water levels, and water quality in the fractured and weathered Mancos Shale.

Core samples from at least one monitor well on the floodplain will be collected starting $5 \mathrm{ft}(1.5 \mathrm{~m})$ above the water table and progressing to the total depth of the borehole for the purposes of geochemical analysis as described in

Section 5.3.8.

Lithologic descriptions will be compiled from borehole cuttings collected during monitor well installation. These cuttings may enhance the understanding of the site geology and the conceptual model.

\section{Data quality objectives for monitor well installation}

The results of the preliminary EM survey will be used to locate monitor wells where they can best quantify actual levels of contamination and further define the ground water flow field. The wells will be 4 inches $(10 \mathrm{~cm})$ in diameter with screens located to optimally detect the plume as indicated by the geophysics or to measure aquifer properties of the various lithologies present at the site. Construction of these wells according to UMTRA Project SOPs (JEG, n.d.) will ensure that the wells will be adequate for the intended purpose. These wells will be constructed with polyvinyl chloride (PVC) materials.

\subsubsection{Piezometer installations}

Six piezometers will be installed on the floodplain close to and along the length of the San Juan River to measure head differences between the river and ground water. Three piezometers will be installed in Bob Lee Wash within the area affected by flow from the artesian well to measure the influence of water flowing from the artesian well into the floodplain aquifer. The piezometers will consist of 2-inch $(5-\mathrm{cm})$ diameter steel well points driven to at least $2 \mathrm{ft}(0.6 \mathrm{~m})$ below the water table. Staff gauges will be installed in the river near each piezometer so that water levels can be measured in the river at the same time 
that measurements are made in the piezometers. A weir will be installed to measure the surface portion of the flow in Bob Lee Wash.

\section{Data quality objectives for piezometer installations}

To ensure accuracy of water level measurements taken from the piezometers, the elevations of the tops of the piezometers, staff gauges, and monitor wells will be surveyed by a certified civil surveyor. The surveyor will certify that the elevations relative to MSL are accurate to plus or minus $0.01 \mathrm{ft}(0.1 \mathrm{~cm})$ or better. Water levels measured in the piezometers, staff gauges, and monitor wells will be measured to within $0.02 \mathrm{ft}(0.1 \mathrm{~cm})$.

\subsubsection{Aquifer testing}

Short-term and long-term aquifer testing will be conducted in selected monitor wells to more accurately quantify the aquifer properties necessary to design an effective remediation system.

The results of the core analysis and existing slug test data will be used to complete the preliminary test design. However, well efficiency cannot be accounted for in the design because it is a parameter that can only be measured in the field. Prior to performing any pumping tests, step drawdown tests lasting about 3 hours each will be performed in each monitor well selected for testing to estimate the optimum pumping rate to be used in the long-term tests. A minimum of three changes in pumping rate will be made.

Following the analysis of the step tests, short-term tests in the form of single well drawdown and recovery tests will be conducted. This will confirm that the general test design (pumping rate and time) is adequate. The results of the first three short-term tests will be evaluated. If there is less than half an order of magnitude of variation in the results, no further short-term tests will be performed.

Long-term pumping tests will be conducted in the two background terrace monitor wells and in existing terrace monitor well 728. Long-term pumping tests will be conducted in at least three new monitor wells on the floodplain. These wells will be selected so that each of the three lithologies on the floodplain will be tested. The tests will be run long enough so the effects of . delayed yield occur. This phase of aquifer response will be analyzed with Neuman's Method (Neuman, 1975). This method allows horizontal-to-vertical anisotropy to be assessed directly. At least one of the short-term tests should be done in a well that will be used for the long-term test to allow checking and cross correlation of the results of the tests. A similar test was performed at another UMTRA Project site that has similar hydraulic properties, requiring 81 hours at about $1.5 \mathrm{gpm}$ to give the desired results. Shiprock will likely have similar requirements in terms of flow rate and duration. 


\section{Data quality objectives for aquifer testing}

Short-term and long-term aquifer test analyses are proposed to determine: 1) the spatial distribution of hydraulic conductivity, 2) how the aquifer responds to conditions similar to those that may be imposed with active remediation, and 3) the effectiveness of the proposed compliance strategies using core and existing slug test data provide a sufficient data base. Standard data loggers and pressure transducers used in accordance with the manufacturer's instructions will produce reliable data for the analysis. Tests will be designed and analyzed according to various standards, such as American Society for Testing Materials (ASTM) standard D4050-1991, "Standard Test Method (Field Procedure) for Withdrawal and Injection Well Tests for Determining Hydraulic Properties of Aquifer Systems."

The short-term tests will be run long enough so that the effects of delayed yield are evident, and then analyzed with Neuman's Method (Neuman, 1975).

For improved accuracy, each test will be analyzed during both the drawdown and recovery phases to cross-check the results. The reasonableness of the test results can be also checked with the core analysis and existing slug test data. The step tests allow estimation of specific capacity (from which transmissivity and hydraulic conductivity can be derived) and well efficiency. Knowledge of these parameters will allow fine tuning of the test in the field to produce optimum results.

\subsubsection{Water quality sampling and analysis}

Water quality samples will be collected and water levels measured at the new and existing monitor wells. Samples will be analyzed for both organic and inorganic constituents. The purpose of the analysis is to quantitatively define the lateral and vertical extent of ground water contamination in the terrace and floodplain aquifers.

Field analyses for $\mathrm{pH}$, Eh, DO, specific conductance, turbidity, and temperature will be performed. The samples will be analyzed for COCs, including antimony, arsenic, cadmium, magnesium, manganese, nitrate, selenium, sodium, strontium, sulfate, and uranium, and other parameters of interest such as TDS, dissolved organic carbon, and other select organic constituents.

\section{Data quality objectives for water quality sampling and analysis}

Each well, including the new monitor wells, will be sampled in accordance with the water and sampling analysis plan for the Shiprock site (DOE, 1994d).

Samples will be collected, preserved, and shipped according to the UMTRA Project SOPS (JEG, n.d.). Samples will be analyzed according to the statement of work (SOW) (TAC, 1993) for the UMTRA project. 
The need for sampling and analyzing the major ions and field parameters is based on two aspects: 1) some of the constituents (e.g., sulfate and uranium) provide an indication of plume behavior and 2) the ground water should be sufficiently well characterized to calculate saturation indices and speciation of the major mineral phases and dissolved constituents likely to occur in the system. The precipitation or dissolution of solid phases may affect the migration rate and concentration of the contaminants.

\subsubsection{Geochemical analysis of lithologic samples}

Core and cuttings samples collected from several of the new monitor wells will be analyzed for mineralogy, cation and anion exchange, sorption potential for select constituents, and other pertinent geochemical parameters that influence and control chemical reactions in the subsurface. These reactions can potentially reduce contaminant concentrations in ground water and need to be understood. The samples will also be batch tested for adsorption properties for the COCs. Results of these analyses will be used to calculate site-specific retardation factors and distribution coefficients.

Data quality objectives for geochemical analysis of subsurface samples

Fresh samples will be used rather than the archived samples because it is not known what changes may have occurred to the cores during the last several years of storage. Use of standard testing procedures (such as ASTM Method 4319, "Distribution Ratios by the Short-Term Batch Method") and standard laboratory quality assurance procedures will generate data suitable for this activity.

\subsubsection{Biological sampling of ground water}

Biological samples will be collected to define the bacteria population in the aquifer and to test the potential for bacteria to reduce and immobilize contaminants in the floodplain aquifer. Bacteria will be isolated from ground water samples collected under an anoxic environment using special procedures and techniques. This information is necessary to design the proposed biological barrier system for remediation of the floodplain aquifer and to determine the potential for natural processes in the remediation of ground water.

\section{Data quality objectives for biological sampling of ground water}

These samples will be analyzed by the research group at the University of New Mexico. Standard techniques will be used as guidelines to sample, preserve, and ship biological samples. Researchers at the University of New Mexico will use standard analytical techniques to enumerate, isolate, and test the nutritional response of bacteria in ground water samples. 


\subsubsection{Surface water and sediment sampling}

Surface water and sediment sampling from the San Juan River and wetland areas on the San Juan River floodplain is required to assess the impact of ground water discharge into the river and wetlands. Sampling should be conducted during a low-flow period in the river. The samples will be analyzed for the same suite of analytes that will be used for analysis of ground water samples from monitor wells.

\section{Data quality objectives for surface water and sediment resampling}

The most recent round of surface water and sediment samples collected during a high-flow period from the San Juan River and the water bodies on the San Juan River floodplain provided inconclusive results. No recent sampling has been conducted in the San Juan River and wetland area during a seasonal lowflow period in the river. Because the potential for contaminated ground water discharging to the river and these water bodies cannot be conclusively ruled out, samples of water and sediment samples will be collected during a low-flow period when the dilution effects associated with the high-flow water conditions are expected to be minimal. The samples will be collected in accordance with UMTRA Project SOPS and developed for the complete suite of analytes.

\subsection{RESULTS AND EVALUATION OF DATA COLLECTION ACTIVITIES}

Upon completion of the data collection activities, Revision 1 of the SOWP will be prepared. Revision 1 will include all previously existing ground water data for the site, a discussion of all field activities, a description of the instrumentation used, the location of the surveys, copies of all field measurement data, copies of field logs, methods of interpretation, and a summary of the results relative to the DCOs.

After completion of the data collection activities, it is proposed that a detailed numerical ground water flow model be constructed that will integrate all the available information about the site. The model will also allow quantitative evaluation of the flow rates required to meet the selected remedial strategy and the possible effects of the uncertainties in the conceptual model (e.g., how well connected to the flow system of the San Juan River is the floodplain aquifer?). The ground water flow model will be used to help design the biological barrier system. 


\subsection{LIST OF CONTRIBUTORS}

The following individuals contributed to the preparation of this report.

\begin{tabular}{ll}
\hline Name & Contribution \\
\hline B. Smith & Principal author \\
B. Smith & Hydrogeology \\
A. Groffman & Geochemistry \\
G. Hartmann & Engineering \\
B. Malczewska-Toth & Risk assessment \\
R. Neri-Zagal & Regulatory compliance \\
J. Gibb, A. Holm, C. Burt & Peer reviewers \\
R. Bennett, R. Bowen, P. Briggs & Senior technical reviewers \\
L. Sanchez & Word processing \\
T. Gagliano, J. Gates, B. Harvey & Graphic design \\
J. Bartel & Technical editing \\
R. Meyers & Document coordinator \\
\hline
\end{tabular}




\subsection{REFERENCES}

AEC (Atomic Energy Commission), 1960. AEC Radiation Control Program for Uranium Mill Operations, May 1960, p.11.

Allison et al. (J. D. Allison, D. S. Brown, K. J. Novo-Gradac) 1991. MINTEQA2/ PRODEFA2, A Geochemical Assessment Model For Environmental Systems: Version 3.0 User's Manual, EPA/600/3-91/021.

CSU (Colorado State University), 1982. "Characterization of Inactive Uranium Mill Tailings Sites: Shiprock, New Mexico," draft, Fort Collins, Colorado.

Dames and Moore, 1982. "Feasibility Evaluation On-Site Stabilization of Uranium Mill Tailings, Shiprock, New Mexico," draft, job no. 10850-059-14, Phoenix, Arizona.

DOC (U.S. Department of Commerce), 1990. 1990 Census of Population, General Population for New Mexico, CPK-1-46, U.S. Department of Commerce, Economics and Statistics Administration, Bureau of Census, Washington, D.C.

DOE (U.S. Department of Energy), 1994a. "Programmatic Environmental Impact Statement for the Uranium Mill Tailings Remedial Action Ground Water Project," draft, April 1994, prepared by the U.S. Department of Energy, UMTRA Project Office, Albuquerque Operations Office, Albuquerque, New Mexico.

DOE (U.S. Department of Energy), 1994b. Baseline Risk Assessment of Ground Water Contamination at the Uranium Mill Tailings Site Near Shiprock, New Mexico, DOE/AL/62350-48F, REV. 1, U.S. Department of Energy, UMTRA Project Office, Albuquerque Operations Office, Albuquerque, New Mexico.

DOE (U.S. Department of Energy), 1994c. UMTRA Project Technical Assistance Contractor Quality Assurance Implementation Plan, DOE/AL/62350-72D, March 1994, prepared by the U.S. Department of Energy, UMTRA Project Office, Albuquerque Operations Office, Albuquerque, New Mexico.

DOE (U.S. Department of Energy), 1994d. UMTRA Project Water Sampling and Analysis Plan, Shiprock, New Mexico, DOE/AL/62350-78, REV. 0, US Department of Energy, UMTRA Project Office, Albuquerque Operations Office, Albuquerque, New Mexico.

DOE (U.S. Department of Energy), 1993. Technical Approach to Groundwater Restoration, DOE/AL/62350-20F, prepared by the U.S. Department of Energy, UMTRA Project Office, Albuquerque Operations Office, Albuquerque, New Mexico. 
DOE (U.S. Department of Energy), 1992. UMTRA Groundwater Program Plan, May 1992, prepared by the U.S. Department of Energy, UMTRA Project Office, Albuquerque Operations Office, Albuquerque, New Mexico.

DOE (U.S. Department of Energy), 1991. Escarpment Seeps at Shiprock, New Mexico, UMTRA-DOE/AL-350214.0000, June 1991, prepared by the U.S. Department of Energy, UMTRA Project Office, Albuquerque Operations Office, Albuquerque, New Mexico.

DOE (U.S. Department of Energy), 1985. Remedial Action Plan and Site Conceptual Design for Stabilization of the Inactive Uranium Mill Tailings Site at Shiprock, New Mexico, UMTRA-DOE/AL-050504.0000, June 1985, prepared by the U.S. Department of Energy, UMTRA Project Office, Albuquerque Operations Office, Albuquerque, New Mexico.

DOE (U.S. Department of Energy), 1984. Processing Site Characterization Report, UMTRA-DOE/AL-0042, 1984, prepared by the U.S. Department of Energy, UMTRA Project Office, Albuquerque Operations Office, Albuquerque, New Mexico.

EPA (U.S. Environmental Protection Agency), 1994. Ground Water Standards for Remedial Action at Inactive Uranium Processing Sites, (Draft Final Rule).

FBDU (Ford, Bacon \& Davis Utah, Inc.), 1981. "Engineering Assessment of Inactive Uranium Mill Tailings, Shiprock Site, Shiprock, New Mexico," UMTRADOE/UMT-0104, FBDU 360-02, Uc-70, prepared by FBDU, Salt Lake City, Utah, for the U.S. Department of Energy, UMTRA Project Office, Albuquerque Operations Office, Albuquerque, New Mexico.

Fetter, C.W., 1993. Contaminant Hydrogeology, Macmillan Publishing Company, New York, New York.

Freeze, A. R. and J. A. Cherry, 1979. Groundwater, Prentice Hall, Inc., Englewood Cliffs, New Jersey, p. 604.

GECR (Geochemistry and Environmental Chemistry Research, Inc.), 1982. "Data for Geochemical Investigation of UMTRAP Designated Site at Shiprock, New Mexico," draft report prepared by G. Markos and U.J. Bush, Geochemistry and Environmental Chemistry Research Inc., Rapid City, South Dakota, for the U.S. Department of Energy, UMTRA Project Office, Albuquerque Operations Office, Albuquerque, New Mexico.

Glikey, M.M., and R.M. Stotelmeyer, 1965. "Water Requirements and Uses in New Mexico Mineral Industries," U.S. Bureau of Mines Information Circular 8276. p. 34-35. 
Goetz, C.L., and Abeyta, C.G., 1987. "Adequacy of NASOAN Data to Describe Areal and Temporal Variability of Water Quality of the San Juan River Drainage Basin Upstream from Shiprock, New Mexico," U.S. Geological Society Water Resources Investigation Report 85-4043, p.89.

Hans, J.M., 1977. EPA Las Vegas Facility, personal communication with H. Tso, Executive Director, Navajo Environmental Protection Commission, Window Rock, Arizona, UPDCC File Location No. 4.19.2.9, Albuquerque, New Mexico, July 13, 1977.

Hsi, C.D., and D. Langmuir, 1985. "Adsorption of Uranyl onto Ferric Oxyhydroxides: Application of the Surface Complexation Site-Binding Model," in Geochim. Cosmochim. Acta, Vol. 49, pp. 1931-1941.

Hunt, R.E., 1984. "Geotechnical Engineering Investigation Manual," McGraw-Hill Book Company, New York, New York, pp. 149-157.

JEG (Jacobs Engineering Group Inc.), n.d. Albuquerque Operations Manual, standard operating procedures, prepared by Jacobs Engineering Group Inc., Albuquerque, New Mexico, for the U.S. Department of Energy, UMTRA Project Office, Albuquerque Operations Office, Albuquerque, New Mexico.

Kent et al. (D.B. Kent, V.S. Tripathy, N.B. Ball, J.O. Leckie, and M.D. Siegel), 1988. Surface-Complexation Modeling of Radionuclide Adsorption in Subsurface Enviranments, NUREG/CR-4807, SAND86-7175, prepared for the Division of High-Level Waste Management Office of Nuclear Material Safety and Safeguards, U.S. Nuclear Regulatory Commission, Washington, D.C.

Leckie et al. (J.O. Leckie, M.M. Benjamin, K. Hayes, G. Kaufman, S. Altmann), 1980. Adsorption/Coprecipitation of Trace Elements From Water With Iron Oxide, EPRI CS-1513, Electric Power Research Institute, Palo Alto, California.

McLean, J.S., and I.A. Johnson, 1987. "Aquifers of the Western Mountain Area," American Water Resources Association Monograph Series, No. 14, pp. 203-217.

Merritt, R. C., 1971. The Extractive Metallurgy of Uranium, Colorado School of Mines Research Institute, prepared under contract with U.S. Atomic Energy Commission, Johnson Publishing Company, Boulder, Colorado.

Nakashima, Satoru, 1992. Complexation and Reduction of Uranium by Lignite, The Science of the Total Environment, 117/118, Elsevier Science Publishers B.V., Amsterdam, the Netherlands, pp. 425-437.

Neuman, S.P., 1975. "Analysis of Pumping Test Data from Anisotropic Unconfined Aquifers Considering Delayed Yield," Water Resources Research, v. 11, no. 2. pp. 329-342. 
NMBMMR (New Mexico Bureau of Mines and Mineral Resources), 1983. Hydrology and Water Resources of San Juan River Basin, New Mexico.

Pierce, M.L., and C.B. Moore, 1980. "Adsorption of Arsenite on Amorphous Iron Hydroxide from Dilute Aqueous Solution," in Environmental Science and Technology, Vol. 14, pp. 214-216.

Public Health Service, 1962. "Stream Surveys in Vicinity of Uranium Mills, IV, Area of Shiprock, New Mexico - November 1960," Division of Water Supply and Pollution Control, Denver, Colorado, December 1962.

Rai, D., and J.M. Zachara, 1984. Chemical Attenuation Rates, Coefficients and Constants in Leachate Migration Volume 1: A Critical Review, EPRI-EA-3356, Volume 1, Battelle, Pacific Laboratories, Richland, Washington.

TAC (Technical Assistance Contractor), 1993. "Statement of Work, UMTRA Project TAC General Inorganic and Radiochemical Analyses," prepared by Jacobs Engineering Group Inc., for the U.S. Department of Energy, UMTRA Project Office, Albuquerque Operations Office, Albuquerque, New Mexico.

Themelis, John G., 1986. Department of Energy (DOE) Project Manager, Uranium Mill Tailings Project Office, personal communication with James Oldham, Project Director, MK-Ferguson Company Inc., Albuquerque, New Mexico, UPDCC File Location No. 4.15.1.3, Albuquerque, New Mexico, August 26, 1986.

Thiers, G.R., 1986. Morrison-Knudsen Engineers, Inc., "Shiprock Remedial Action Case Study," presented at the U.S. Department of Energy Remedial Action Programs Conference, Oak Ridge, Tennessee, May 6, 1986.

\section{CODE OF FEDERAL REGULATIONS}

10 CFR Part 1021, "National Environmental Policy Act; Implementing Procedures and Guidelines Revocation; Final Rule and Notice," U.S. Department of Energy (1994).

40 CFR Part 192, "Health and Environmental Protection Standards for Uranium and Thorium Mill Tailings," U.S. Environmental Protection Agency (1994).

40 CFR Part 264, Standards for Owners of Hazardous Waste Treatment, Storage, and Disposal Facilities, U.S. Department of Energy (1994).

40 CFR Part 1500, "Regulations for Implementing the Procedural Provision of the National Environmental Policy Act," Council on Environmental Quality (1994). 


\section{FEDERAL CODE}

52 FR 36000, "Standards for Remedial Actions at Inactive Uranium Processing Sites, Proposed Rule," September 24, 1987.

\section{UNITED STATES CODE}

42 USC $\$ 7901$ et seq., Uranium Mill Tailings Radiation Control Act, November 8, 1978.

42 USC $\$ 4321$ et seq., National Environmental Policy Act, January 1, 1970. 